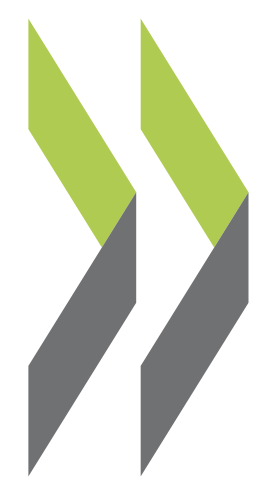

OECD Social, Employment and Migration Working Papers No. 95

\title{
Looking Inside the Perpetual-Motion Machine: Job and Worker Flows in OECD Countries
} Andrea Bassanini, 
Organisation de Coopération et de Développement Économiques

Organisation for Economic Co-operation and Development

15-Sep-2009

DIRECTORATE FOR EMPLOYMENT, LABOUR AND SOCIAL AFFAIRS

English - Or. English EMPLOYMENT, LABOUR AND SOCIAL AFFAIRS COMMITTEE

OECD SOCIAL, EMPLOYMENT AND MIGRATION WORKING PAPERS NO. 95

LOOKING INSIDE THE PERPETUAL-MOTION MACHINE: JOB AND WORKER FLOWS IN OECD COUNTRIES

Andrea Bassanini and Pascal Marianna

JEL Codes: J23, J24, J63

JT03269626

Document complet disponible sur OLIS dans son format d'origine Complete document available on OLIS in its original format 


\title{
OECD SOCIAL, EMPLOYMENT AND MIGRATION WORKING PAPERS
}

\author{
www.oecd.org/els/workingpapers
}

This series is designed to make available to a wider readership selected labour market, social policy and migration studies prepared for use within the OECD. Authorship is usually collective, but principal writers are named. The papers are generally available only in their original language - English or French - with a summary in the other.

Comments on the series are welcome, and should be sent to the Directorate for Employment, Labour and Social Affairs, 2, rue André-Pascal, 75775 PARIS CEDEX 16, France.

The opinions expressed and arguments employed here are the responsibility of the author(s) and do not necessarily reflect those of the OECD.

\author{
Applications for permission to reproduce or translate \\ all or part of this material should be made to: \\ Head of Publications Service \\ OECD \\ 2, rue André-Pascal \\ 75775 Paris, CEDEX 16 \\ France \\ Copyright OECD 2009
}




\section{ACKNOWLEDGEMENTS}

This paper is a background paper for Chapter 2 of the 2009 edition of the OECD Employment Outlook. Nevertheless, the views expressed here are those of the authors and cannot be attributed to the OECD or its member countries. Andrea Bassanini and Pascal Marianna are, respectively, Senior Economist and Economist at the Employment Analysis Division of the Directorate for Employment, Labour and Social Affairs of the OECD. Sebastien Martin, Dana Blumin, Thomas Manfredi and Agnes Puymoyen provided skilful research assistance. The authors are indebted to Eric Bartelsman and Alex Hijzen for sharing their data with them and to Jens Arnold, Koen De Backer, Sarah Donovan, Martine Durand, Andrea Garnero, Claire Lelarge, John Martin, Alfonso Rosolia, Cyril Schwellnus, Paul Swaim, Ken Swinnerton, participants to the Mars 2009 meeting of the ELSAC Working Party on Employment and, especially, Stefano Scarpetta, for comments, discussions and suggestions. Standard caveats apply. 


\section{SUMMARY}

In the economic literature there is an increasing interest in the process of job creation and destruction as well of hirings and separations. Many studies suggest that idiosyncratic firm-level characteristics shape both job and worker flows in a similar way in all countries. Others argue that cross-country differences in terms of gross job flows are minor. However, these statements are usually based on the comparison of national estimates, typically collected on the basis of different definitions and collection protocols. By contrast, in this paper, we use crosscountry comparable data on both job and worker flows to examine key determinants of these flows and of their cross-country differences. We find that idiosyncratic firm (industry, firm age and size) and worker (age, gender, education) characteristics play an important role for both gross job and worker flows in all countries. Nevertheless, in contrast with part of the literature, we find that, even controlling for these idiosyncratic factors, cross-country differences concerning both gross job and worker flows appear large and of a similar magnitude. Both job and worker flows in countries such as the United States and the United Kingdom exceed those in certain continental European countries by a factor of two. Moreover, the variation of worker flows across different dimensions is well explained by the variation of job flows, suggesting that, to a certain extent, the two flows can be used as substitutes in cross-country analysis. Consistently, churning flows, that is flows originating by firms churning workers and employees quitting and being replaced, display much less variation across countries.

\section{RÉSUMÉ}

La littérature économique consacre un intérêt de plus en plus grand pour le processus de création et de destruction d'emplois ainsi que pour les flux d'embauches et de séparations. Plusieurs études soulignent que les caractéristiques propres aux entreprises façonnent les flux d'emplois et de main d'œuvre de manière similaire dans tous les pays. D'autres soutiennent que les différences inter-pays des flux bruts d'emplois ne sont pas très grandes. Cependant, ces constats s'appuient généralement sur des comparaisons d'estimations nationales reposant sur différentes définitions et protocoles de collecte de données. En revanche, dans ce papier, nous utilisons des données comparables entre les pays sur les flux d'emplois et de main d'œuvre afin d'examiner les déterminants principaux de ces flux et des différences inter-pays. Nous trouvons que les caractéristiques propres aux entreprises (le secteur d'activité, l'âge et la taille des entreprises) et aux salariés (l'âge, le sexe et le niveau d'éducation) jouent un rôle important pour les flux d'emplois et de main d'œuvre dans tous les pays. Néanmoins, contrairement à une partie de la littérature, nous trouvons que, même à structure constante pour ces caractéristiques, les différences inter-pays des flux d'emplois et de main d'œuvre demeurent importantes et de même ampleur. Les flux d'emplois et de main d'œuvre aux États-Unis et au Royaume-Uni sont deux fois plus importants que ceux observés dans certains pays d'Europe continentale. En outre, la variation des flux de main d'œuvre selon différentes dimensions est bien expliquée par la variation des flux d'emplois, ce qui permet de suggérer, dans une certaine mesure, que les deux variables peuvent être utilisées comme des substituts dans les analyses inter-pays. En revanche, les flux de déplacement de la main d'œuvre, résultant de la substitution des salariés sur les mêmes emplois opérée par les entreprises ou par les départs et remplacement de salariés, sont marqués par nettement moins de variation entre les pays. 


\section{TABLE OF CONTENTS}

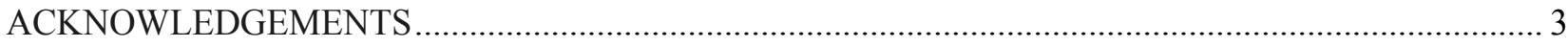

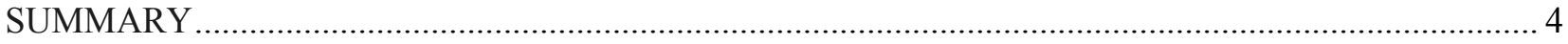

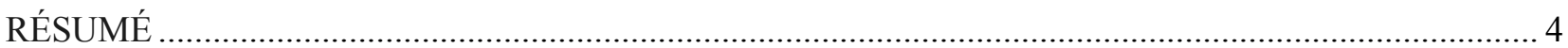

LOOKING INSIDE THE PERPETUAL-MOTION MACHINE: JOB AND WORKER FLOWS IN OECD

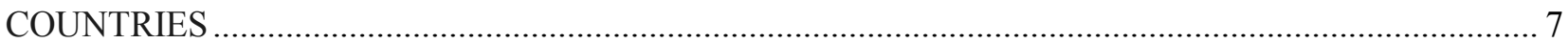

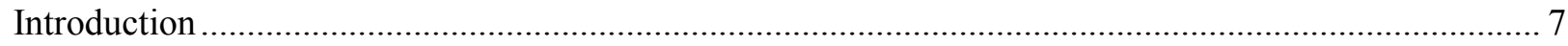

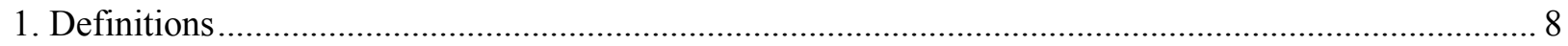

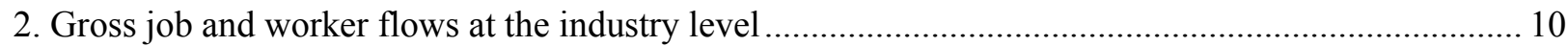

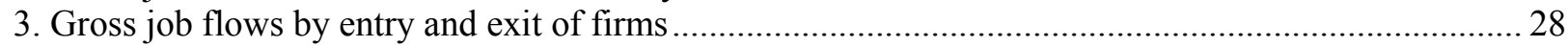

4. Firm-level evidence on gross job flows: the case of medium and large continuers ............................. 32

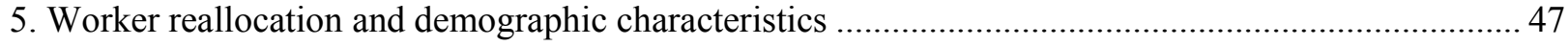

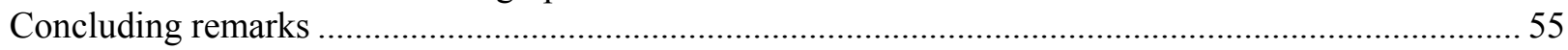

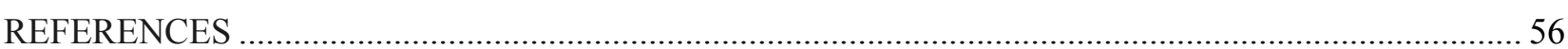

\section{Tables}

Table 1. Average gross job reallocation rates, by industry 1997-2004......................................... 14

Table 2. Within country/cross - industry correlations of job creation and destruction rates............... 16

Table 3. Analysis of variance of cross-country/cross-industry data on gross job flow rates............... 17

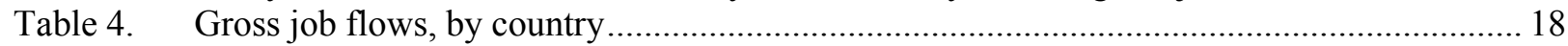

Table 5. Average worker reallocation rates, by industry 2000-2005 …......................................... 20

Table 6. Analysis of variance of cross-country/cross-industry data on worker flow rates.................... 23

Table 7. Within country/cross -industry correlations of hiring and separation rates ........................ 24

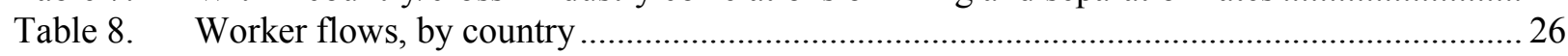

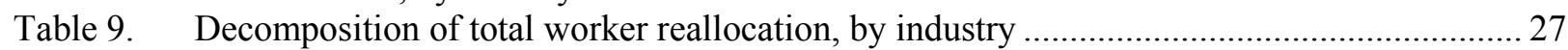

Table 10. Decomposition of total worker reallocation, by country .................................................. 28

Table 11. Analysis of variance of cross-country/cross-industry data on gross job creation and

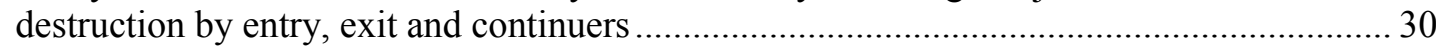

Table 12. Job reallocation due to firm entry and exit, by country ................................................. 31

Table 13. Analysis of variance of job-flow data for medium and large continuing firms across countries, industries, firm size classes and firm age classes................................................. 35

Table 14. Quantifying the effect of firm age on job destruction for medium

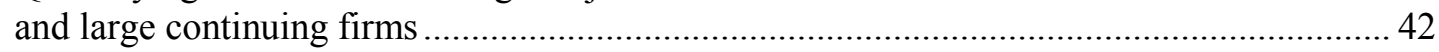

Table 15. Within country/cross - cell correlations of job creation and destruction rates........................ 43

Table 16. Residual correlation coefficients between employment growth and productivity................... 46

Table 17. Analysis of variance of prime-age worker flows across countries, industries, gender, age,

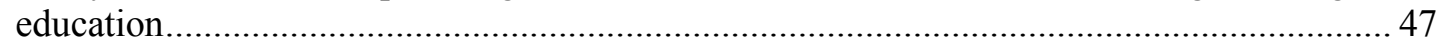

Table 18. Worker flows by country and individual characteristics ................................................... 49 


\section{Figures}

Figure 1. Country-specific and average industry distributions of gross job reallocation rates .....

Figure 2. Cross-industry correlation of country-specific and average rates of job creation and destruction 16

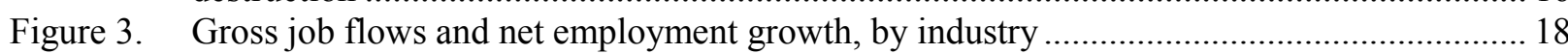

Figure 4. Job creation, job destruction and net employment growth by country .............................. 19

Figure 5. Country-specific and average industry distributions of worker reallocation rates ............... 21

Figure 6. Cross-industry correlation of country-specific and average hiring and separation rates ...........23

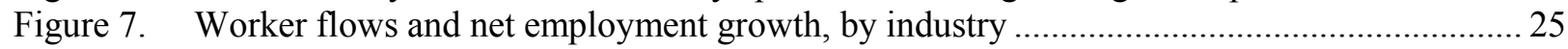

Figure 8. Contribution of firm entry and exit to gross job reallocation .............................................. 29

Figure 9. Cross-industry correlation of country-specific and average job creation

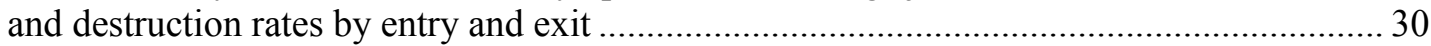

Figure 10. Within country/cross - industry correlations of job creation and destruction rates............... 32

Figure 11. Country-specific and average job reallocation rates, by industry, firm-size

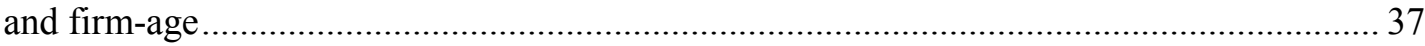

Figure 12. Job creation and destruction as a function of firm-size ...................................................... 38

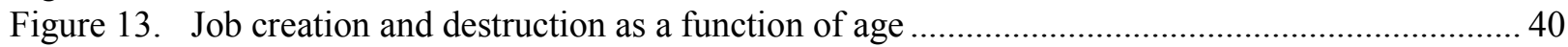

Figure 14. Correlation of country-specific and average hiring and separation rates across industries,

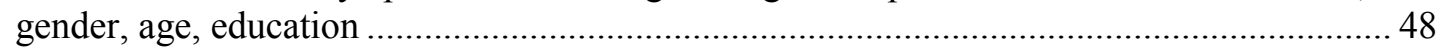

Figure 15. Worker flows by industry and individual characteristics ............................................... 52 
DELSA/ELSA/WD/SEM(2009)23

\section{LOOKING INSIDE THE PERPETUAL-MOTION MACHINE: JOB AND WORKER FLOWS IN OECD COUNTRIES}

\section{Introduction}

1. There is an increasing attention in the economic literature to the process of job creation and destruction (commonly referred to as gross job flows) as well of hirings and separations (commonly referred to as gross worker flows). There is also an increasing interest for hiring and separations due to firm churning workers, that is in excess of job creation and destruction (e.g. Burgess et al., 2000). These processes appear to be at the heart of the functioning of market-based economies which entail a continuous process of creative destruction of jobs and job-matches: Each day, new firms start up; existing firms expand, contract and eventually shut down; individuals are hired to fill new positions or to replace previous employees on existing jobs; others quit or are dismissed. Within this context, many studies point to the importance of idiosyncratic firm-level characteristics, which appear to have similar effects in all countries, to explain both job and worker flows (e.g. Davis and Haltiwanger, 1999). Some studies argue that job-flow differences across countries are small while worker-flow differences are larger, and devote a lot of theoretical effort in explaining the disparity of patterns between job and worker flows (see for example Bertola and Rogerson, 1997, Pries and Rogerson, 2005). However, these statements are usually based on the comparison of national estimates, typically collected on the basis of different definitions and collection protocols. Cross-country comparable data on job and worker flows have been rarely used to describe crosscountry differences (Haltiwanger et al., 2006, is one of the few exceptions) ${ }^{1}$ and, as far as we know, no study have simultaneously used comparable data on both job and worker flows.

2. In this paper, we make an attempt at filling this gap by exploiting gross job flows assembled using the same data collection protocol at the firm level and worker flows derived from labour force surveys to construct cross-country comparable industry-level and micro datasets that we use to revisit stylised facts concerning gross job and worker flows in OECD and few other countries. To anticipate our main conclusions, we find that both idiosyncratic firm (industry, age and size) and worker (age, gender, education) characteristics are key factor affecting gross job and worker flows in all countries. Nevertheless, even controlling for these idiosyncratic factors, cross-country differences concerning both gross job and worker flows appear large and of a similar magnitude. Both job and worker flows in countries such as the United States and the United Kingdom exceed those in certain continental European countries by a factor of two. Moreover, the variation of worker flows across different dimensions is well explained by the variation of job flows, suggesting that, to a certain extent, the two variables can be used as substitutes in cross-country analysis. Consistently, churning flows, that is flows originating from firms churning workers and employees quitting and being replaced, display much less variation across countries.

3. The paper is organised as follows: Section 1 defines the key empirical concepts of gross job and worker reallocation that are the object of this paper, and relate our measures to the main definitions used in the literature. Section 2 looks at cross-country/cross-industry patterns of gross job and worker reallocation. Section 3 revisits these patterns by examining the contribution of start-ups, shutdowns and continuers. Section 4 examines the role of specific firm characteristics, such as age and size, by using comparable

1. Another exception is Wolfers (2009), who derives implications for gross job flows on the basis of crosscountry comparable measures of seasonal reallocation rates based on household surveys. 
micro-data concerning medium and large continuers. Finally, section 5 revisits worker flows by looking at the role of individual worker characteristics. Each of these sections contains a subsection discussing methodology and data. Some concluding remarks are presented in Section 6.

\section{Definitions}

4. At the level of an individual production unit (the firm in this paper), gross job reallocation (also commonly called gross job turnover, see for example Davis and Haltiwanger, 1992, 1999, Davis et al., 1996, and OECD, 1996), is simply the absolute value of the net change in employment between two points in time. In this terminology, job creation, at the level of the individual firm, is equal to the net employment change, if the latter is positive, and zero otherwise. Conversely, job destruction, is equal to the absolute value of the net change, if the latter is negative, and zero otherwise. Job reallocation, job creation and job destruction are commonly called gross job flows, in order to differentiate them from the more familiar measures of net employment growth. Net and gross job flows coincide at the level of a single firm, but that is no longer the case when groups of firms are considered. For brevity, we often omit the qualifier "gross" when the context makes it clear that the flows being discussed are gross flows. Gross flows are defined so as to be non-negative. They are also defined so as to exclude job vacancies which remain unfilled or jobs that begin and end within the interval of observation.

5. Gross worker flows reflect movements of workers into jobs (hirings) and out of jobs (separations) over a specified period of time. A measure of worker flows over a specified period could be based on: $i$ ) a full counting of all events during that period (i.e. every time a worker is hired or separates during the period); or ii) a more limited counting based on comparing two points in time (i.e. hirings equal the number of workers who are with the firm at time $t$, but were not with that employer at time $t-1$, and separations equal the number of workers who were with the firm at $t-1$, but not at $t$ ). Davis and Haltiwanger (1999) refer to the first definition as worker turnover and the second definition as worker reallocation. A number of intermediate definitions are also possible (see e.g. Davis et al., 2006). Different definitions, however, result in entirely different estimates of worker flows, as can be illustrated with the following hypothetical example. Suppose a given firm had ninety-five employees at year t- 1 and has 105 at t. During this period, ten people were hired to fill newly created posts. Suppose also that five other workers left the firm and were replaced by new recruits, another five workers were temporarily laid-off but recalled during the period and yet another five people were hired on fixed-term contracts that expired during the period and were not renewed. Job reallocation at the level of this firm (i.e. the absolute value of the net change in employment, as defined above) is equal to ten. By contrast, worker reallocation would be equal to forty or twenty according to definitions $i$ ) or ii), respectively (intermediate definitions would lead to intermediate numbers, see Davis et al., 2006). Because of data availability, we adopt the second definition, which is not uncommon in the literature (e.g. Abowd et al., 1999, and Golan et al., 2006) and has nonetheless the additional advantage of being conceptually similar to that used for job flows, thereby allowing meaningful comparisons between the two sets of estimates. Whatever the definition, however, the following identity holds for each firm $i$ at each time $t$ :

$$
\Delta E_{i t}=J C_{i t}-J D_{i t}=H_{i t}-S_{i t}
$$

where $E, J C, J D, H$ and $S$ stand for employment, job creation, job destruction, hirings and separations and $\Delta$ for differences between time $t-1$ and $t$.

6. In this paper we use one year as reference period. This implies that firm-level gross job flows refer to employment changes over a one year time span. Similarly hirings and separations are defined as one-year transitions across different employers and/or employment statuses. As firm-level employment is subject to short-term fluctuations (due for example to seasonal activity, temporary fluctuations in product demand or difficulties in filling vacancies after quits) and workers can change many jobs during a given 
time period, it is important to keep in mind that the period of time over which these flows are measured is key. For example, the annual rates of job creation and destruction analysed in this paper will tend to be smaller than the sum of flows that can be calculated at a higher frequency during the same year (e.g. the sum of quarterly flows for all the four quarters of a given year).

7. At a greater level of aggregation (e.g. a group of firms with given characteristics, the industry, or the whole economy), job reallocation, job creation and job destruction can be obtained by simply adding up their values over all of the firms in the group being considered. Put it another way, job creation is the sum of employment growth at all entering and expanding firms, while job destruction is the total number of jobs lost at exiting and contracting firms. Note too that net employment growth for the group is simply the difference between job creation and job destruction, while job reallocation can also be calculated at the group level as the sum of job creation and destruction. Finally, it is useful to define excess job reallocation as the difference between total job reallocation and the absolute net change in total employment - that is for, say, industry $j$ at time $t$ :

$$
E X C J_{j t}=R E A L J_{j t}-\left|\Delta E_{j t}\right|=J C_{j t}+J D_{j t}-\left|J C_{j t}-J D_{j t}\right|
$$

where EXCJ and REALJ stand for excess and total gross job reallocation, respectively. Excess job reallocation provides therefore a measure of simultaneous and off-setting job creation and job destruction by different firms belonging to the same group. In other words, excess job reallocation represents the reallocation of labour resources between firms within the same group whereas the group's absolute net employment change provides a measure of reallocation across different groups of firms (e.g. different industries).

8. Worker flows are aggregated in an analogous manner, that is, by summing hirings and separations over all members of the specified group, where the group can be defined in terms of either groups of firms (e.g. all firms in an industry) or all workers sharing a particular demographic characteristic (e.g. belonging to a given age class or gender). According to the definition of hirings and separations adopted for this paper (i.e. one-year transitions), group-level hirings (separations) will be simply the number of workers with the given characteristics who were with one employer in year $t$ but not with the same employer in t-1 (workers with given characteristics who were with one employer at time t-1, but not at $\mathrm{t}$ ). As with job flows, for any group of job matches involving individuals with the same characteristics (e.g. a particular age or employed in a particular industry), we can define excess worker reallocation as the difference between total worker reallocation and the group's absolute net change in employment - that is for, say, industry $j$ at time $t$ :

$$
E X C W_{j t}=R E A L W_{j t}-\left|\Delta E_{j t}\right|=H_{j t}+S_{j t}-\left|H_{j t}-S_{j t}\right|
$$

where EXCW and REALW stand for excess and total gross worker reallocation, respectively. Excess worker reallocation provides a useful measure of the number of job matches that are created and destroyed, over and above the minimum necessary to accommodate net employment growth. In other words, it reflects the reallocation of job matches (the reshuffling of jobs and workers) within the same group.

9. At the firm, industry or economy-wide level, it is possible to compare job and worker flows. Following Burgess et al. (2000), we can define churning flows as the difference between excess worker reallocation and excess job reallocation - that is for, say, industry $j$ at time $t$ :

$$
C H_{j t}=E X C W_{j t}-E X C J_{j t}=R E A L W_{j t}-R E A L J_{j t}=H_{j t}+S_{j t}-J C_{j t}-J D_{j t}
$$


where $\mathrm{CH}$ stands for churning flows. While absolute net employment growth and excess job reallocation represent the reallocation of labour resources across industries and between firms of the same industry, respectively, the difference between excess worker and job reallocation represents labour reallocation arising from firms churning workers through continuing jobs or employees quitting and being replaced on those jobs.

10. Finally, consistent with the literature (see e.g. Davis and Haltiwanger, 1999), all labour market flow measures from $t$-1 to $t$ are expressed in this paper as rates by dividing flow totals by average employment in $t-1$ and $t$. In the hypothetical example above, the job reallocation rate is $10 \%$, while the worker reallocation rate is $20 \%$, in the definition adopted for this paper (one-year transitions), and the churning rate is $10 \%$.

\section{Gross job and worker flows at the industry level}

\subsection{Data and methodology}

11. In order to produce cross-country comparable tables on job creation and destruction rates at the industry-level, we combine two sources of data on job flows at the industry-level concerning the 1997-2004 period (Haltiwanger et al., 2006, and Bartelsman, 2008). These two sources provide gross job turnover rates constructed from business registers and tax files using the same protocol and therefore comparable across countries. These data refer to firms as unit of observation defined as "an organisational unit producing goods or services which benefits from a certain degree of autonomy in decision-making, especially for the allocation of its current resources". Data from these two sources are available on an annual basis for different periods but, for a few countries (Brazil, United Kingdom), industry coverage is limited to manufacturing. In principle, all these sources report information on entry and exit of firms as well as on continuers - that is incumbent firms that are active at both $t-1$ and $t$. However, due to the way information is aggregated, data from Haltiwanger et al. (2006) and Bartelsman (2008) do not include, for each given year $t$, job creation and job destruction by continuers that will exit in the following year (or to put it differently these data do not contain information on net employment growth between $t-1$ and $t$ of firms that will exit in $t+1$ ). As a consequence, job turnover of continuers is underestimated in these data. Using data provided to the OECD by the Census Bureau for the United States, it is possible to evaluate this downward bias to no more than $10 \%$ in most industries in the United States, except in two industries (mining and telecommunications), where the downward bias, however, appears to be far greater - up to $30 \%$. These industries are therefore either excluded (mining) or aggregated with other industries (telecommunications) in all countries. ${ }^{2}$

12. Overall, we have data on total job flows (entry, exit and continuers, subject to the caveats specified above) for 11 countries: eight OECD countries (Finland, Germany, Hungary, Mexico, Portugal, Sweden, the United Kingdom, and the United States) two accession countries (Estonia and Slovenia) and one enhanced-engagement country (Brazil).

13. In this paper we are interested in describing and comparing job and worker flows across countries using comparable data. As discussed in the introduction, our aim is not only to provide facts concerning cross-country regularities in the within-country distribution of labour reallocation flows, but also to document differences in the intensity of these flows in different countries. The industry dimension is key in this respect: given the importance of the cross-industry variation documented in the literature (see for

2. In a sensitivity analysis we also use average job turnover for 1998-2005 from Hijzen et al. (2007) for the United Kingdom that have the advantage of including also services. However, since these data do not exclude continuers that exit in $\mathrm{t}+1$, they are, strictly speaking, not comparable to ours, even though probably less affected by measurement error. For this reason we use them only in a sensitivity analysis. 
example Davis and Haltiwanger, 1999, and Micco and Pages, 2006), countries that specialise in lowmobility industries might end up with low aggregate reallocation rates even if they have above-average reallocation rates in all industries. This suggests that data must be adjusted for the industry-composition to produce meaningful aggregate statistics. Adjustment is also necessary because data are not available for certain industries in certain countries - for instance, in our dataset, unadjusted data for Brazil or the United Kingdom would be clearly incomparable with other countries, because we have data for manufacturing only for these two countries (see above). We adjust, therefore, aggregate rates for industrycomposition using the following procedure: first, employment shares of each industry are computed for each country and then averaged across countries; second, a weighted regression of industry/country rates on industry and country dummies is estimated using frequency weights proportional to employment shares and imposing the constraint that the average of the coefficients of country dummies is equal to the global average. Estimated coefficients of country dummies will then correspond to the adjusted rates.

14. In order to estimate worker flows among dependent employees (henceforth simply called employment), we use data from the European Labour Force Survey (EULFS) and the bi-annual January Displaced workers/Job tenure supplement of the Current Population Survey (CPS), for even years for the United States. Drawing on Bassanini et al. (2009), we are able to disaggregate these data at the OECDSTAN level, an intermediate level between 1 and 2 digits in the ISIC rev. 3 classification, resulting in 24 industries in the non-farm business sector. We start by constructing annual hiring and separation rates computed using the methodology explained below. However, in narrowly-defined industries they might vary considerably from year to year due to the small sample size (and the fact that the industry is typically not included in LFS sample designs). To filter out these, by and large, spurious movements, averages across years are calculated. We end up with a sample of 22 countries (Norway, Switzerland, Turkey, the United States and European Union countries, except Bulgaria, Cyprus, Estonia, Latvia, Lithuania, Luxembourg, Malta, the Netherlands and Romania).

15. According to the definition spelled out in the previous section, hirings $(H)$ correspond to the number of dependent employees who have been working for their current employer for no more than the past 12 months including the survey reference week. Symmetrically, job stayers $(J S)$ are defined as those who have been working for more than one year with the same employers. Employment, excluding observations with missing job tenure information $\left(E_{-} T\right)$, is defined as the sum of the two terms:

$$
E_{-} T_{i j t m}=H_{i j t m}+J S_{i j t m}
$$

where $i$ refers to countries, $j$ to industries, $t$ to years and $m$ to worker characteristics such as gender, age and education. ${ }^{3}$ Separations reflect movements out of jobs in the past 12 months and are obtained by exploiting the basic accounting identity:

$$
S_{i j t m}=H_{i j t m}-\Delta E_{-} T_{i j t m}
$$

16. However, adjustments are necessary because $i$ ) missing tenure information and/or errors in the reporting of job tenure data might differ between two survey waves; and ii) employment movements at disaggregate industry level in LFS might differ from those reported in national accounts, with the latter being typically more accurate than the former at the industry-level. Let us examine these adjustments in order.

3. Data disaggregated by gender, age and education are used in Section 5 only. However, to avoid repetitions we explain here the procedure of construction of worker flows also for disaggregated data. 
17. First, an adjusted lagged value of $E_{-} T$ (called $L E_{-} T$ hereafter) is defined in such way that it is consistent over time with $E_{-} T$ and with year-to-year employment changes resulting from LFS employment data without excluding observations with missing tenure $(E)$.

$$
L E_{-} T_{i j t m}=E_{i j(t-1) m} \frac{E_{-} T_{i j t m}}{E_{i j t m}}
$$

$L E \_T$ is further adjusted to account for cohort effects affecting beginning and end years of age groups to produce unbiased year-on-year employment changes by age group.

18. Second, the distribution of employment across worker groups is combined with industry-level employment from the March 2008 public release of EUKLEMS (denoted with $E_{-} K$ ). ${ }^{4}$ For countries for which EUKLEMS data are not available, we simply set $E_{-} K=E$. More precisely, we derive an adjusted employment level that can be used in the accounting identity [5] as follows:

$$
E_{-} \text {corr }_{i j t m}=E_{-} T_{i j t m} \frac{E_{-} K_{i j t}}{E_{-} T_{i j t}}
$$

19. Similarly, we compute one-year lagged employment as follows:

$$
E_{-} \operatorname{corr}_{i j(t-1) m}=L E_{-} T_{i j t m} \frac{E_{-} K_{i j t-1}}{L E_{-} T_{i j t}}
$$

20. Adjusted hirings, consistent with EU-KLEMS employment, are then derived from:

$$
H_{-}{ }^{c o r r} r_{i j t m}=\frac{H_{i t j m}}{E_{-} T_{i t j m}} E_{-} \text {corr }_{i j t m}
$$

21. Then, we obtain hiring rates from:

$$
H R_{i j t m}=\frac{H_{-}{ }^{c o r r} i_{i t j m}}{1 / 2\left(E_{-}{ }^{c o r r} r_{i t j m}+E_{-} \operatorname{corr}_{i(t-1) j m}\right)}
$$

22. Then we obtain adjusted separations (S_corr) from the following accounting identity:

$$
E_{-} \operatorname{corr}_{i j t m}=E_{-} \operatorname{corr}_{i j(t-1) m}+H_{-} \operatorname{corr}_{i j t m}-S_{-} \operatorname{corr}_{i j t m}
$$

23. Hence

$$
S_{-} \text {corr }_{i j t m}=H_{-} \text {corr }_{i j t m}-\Delta E_{-} \text {corr }_{i j t m}
$$

24. Finally, we obtain separation rates from:

4. EUKLEMS is a publicly available dataset, sponsored by the European Commission that contains several cross-country comparable variables derived from national accounts and available at the industry-level. 


$$
S R_{i j t m}=\frac{S_{-} \operatorname{corr}_{i j m}}{1 / 2\left(E_{-} \operatorname{corr}_{i t j m}+E_{-} \operatorname{corr}_{i j(t-1) m}\right)}
$$

25. We obtain churning rates simply as difference between gross worker and job flows for countries, industries and years where both are available, consistent with equation [4]. However, some caution on this derivation is in order. In contrast with several country-specific studies that compare job and worker flows using data from the same firm-level source (see among others Hamermesh et al., 1996, Albaek and Sorensen, 1998, Abowd et al., 1999, Burgess et al., 2000, Hohti, 2000, Arai and Heyman, 2001, Haltiwanger and Vodopivec, 2002, 2003, Ilmakunnas and Maliranta, 2003, Golan et al., 2006, Davis et al., 2006, and Corseuil, 2008), we use firm-level sources for gross job flows and labour force surveys for worker flows. The reason for doing so is motivated by the need of cross-country comparability. In fact, it is difficult to establish the extent to which the results of country-specific studies can be compared across countries due to cross-country differences in definitions and survey structures. Yet, how reliable are the figures obtained in this way? Estimates from Davis et al. (2006) can provide a good benchmark, insofar as they use data from the same enterprise survey and a definition of worker flows similar to that used in this paper (except for being quarterly). They find that churning flows represented on average $46 \%$ of total worker flows in ten US states between 1998 and 2002. According to the data used in this paper, aggregate US churning flows amounted to 33\% of total US worker flows between 2002 and 2004. These two estimates do not appear too different if one takes into account the fact that the ratio of worker to job flows is likely to be larger in quarterly data and that worker flows can be seriously overestimated in enterprise surveys due to transcription and coding errors (by up to $15 \%$ in the United States, see Abowd and Vilhuber, 2005, Benedetto et al., 2007).

\section{$2.2 \quad$ Gross job flows}

26. Table 1 shows average industry gross job flows for the countries for which we have comparable data (see above). Average annual gross job reallocation was about $22 \%$ of dependent employment in the business sector between 1997 and 2004. Of this, industry-level excess job reallocation at our level of aggregation was on average about $18 \%$ of dependent employment, suggesting that about $9 \%$ of all jobs were destroyed in some firms but were offset by an equal number of jobs created in other firms within the same industry every year. In other words, at this level of aggregation, jobs created and destroyed within one industry are almost three times as many as jobs created or destroyed due to net employment growth and reallocation of labour resources across industries. At a comparable level of aggregation, similar findings are reported by OECD (1996), Davis and Haltiwanger (1999), Micco and Pages (2006) and Haltiwanger et al. (2006).

27. Gross job flows, however, vary dramatically across industries (Table 1). At our level of aggregation, average excess job reallocation is as high as $28 \%$ in real estate services, possibly due to fluctuations in housing demand and the small size of firms in this industry (see below) and as low as $8 \%$ in the electricity, gas and water supply industry (likely due to the large and stable market share of big corporations in this industry). Put another way, between $4 \%$ and $14 \%$ of jobs, on average, are destroyed each year, while being offset by job creation at other firms in the same industry. Construction and service industries (except financial intermediation, transport and communications) have above-average excess job reallocation. A couple of manufacturing industries (wood and other manufacturing and recycling) are close to or above the average of all industries for excess job reallocation. The electricity, gas and water supply, and chemicals, rubber, plastics and fuel industries show very low rates of reallocation, while the remaining industries, mostly manufacturing, display below-average rates of excess job reallocation, with relatively little variation among them. Textiles and electrical and optical equipment manufacturing belong to this latter group, when looking at excess reallocation, but are close to the average of all industries when total 
reallocation is considered, due to the steady downsizing trend of the former and widespread expansion of the latter.

Table 1. Average gross job reallocation rates, by industry 1997-2004

Average percentage rates

\begin{tabular}{ll|c|c|c}
\hline & \multicolumn{1}{c|}{ Industry } & Excess reallocation & Absolute net growth & Total \\
\hline $15-16$ & Food, beverages and tobacco & 17.1 & 2.8 & 19.9 \\
$17-19$ & Textiles, leather and footwear & 17.8 & 3.5 & 21.3 \\
20 & Wood and manufacturing of wood and cork & 18.4 & 3.7 & 22.1 \\
$21-22$ & Pulp, paper, printing and publishing & 16.8 & 2.2 & 19.0 \\
$23-25$ & Chemicals, rubber, plastics and fuel & 17.2 & 2.4 & 19.6 \\
26 & Other non-metallic mineral products & 16.9 & 3.1 & 19.9 \\
$27-28$ & Basic metals and fabricated metal & 18.1 & 2.9 & 18.4 \\
29 & Machinery, not elsewhere classified & 15.5 & 2.9 & 22.2 \\
$30-33$ & Electrical and optical equipment & 16.7 & 5.5 & 20.5 \\
$34-35$ & Transport equipment & 15.9 & 4.6 & 23.3 \\
$36-37$ & Other manufacturing; Recycling & 20.0 & 3.2 & 10.5 \\
$40-41$ & Electricity, gas and water supply & 7.8 & 2.7 & 27.6 \\
45 & Construction & 23.2 & 4.4 & 24.3 \\
$50-52$ & Wholesale and retail trade & 21.3 & 3.0 & 26.9 \\
55 & Hotels and restaurants & 23.6 & 3.3 & 19.0 \\
$60-64$ & Transport, storage and communications & 16.5 & 2.5 & 20.3 \\
$65-67$ & Financial intermediation & 16.2 & 4.0 & 32.3 \\
70 & Real estate activities & 27.6 & 4.8 & 32.3 \\
$71-74$ & Other business services & 25.3 & 7.0 & 21.9 \\
Average & & 18.4 & 3.5 & \\
\hline
\end{tabular}

Note: ISIC rev. 3 codes for industries. Data refer to: Brazil: 1998-2000; Estonia: 2003; Germany: 1997-98; Finland: 1997; Hungary: 1998-2000; Portugal: 1997; Mexico: 2000; Slovenia: 2002-03; Sweden: 1997-2003; United Kingdom: 1997-98; United States: 200104.

28. Are these average distributions invariant across countries? Figure 1 shows that industry distributions of job turnover rates are strongly correlated across countries. For all countries, the distribution of job flow rates is significantly correlated with the average distribution presented in Table 1, with the sole exception of the United Kingdom, consistent with previous findings in the literature (e.g. Micco and Pages, 2006, and Haltiwanger et al., 2006). ${ }^{5}$ A similar picture emerges if we look at job creation and job destruction rates separately (Figure 2). This is not surprising since, within countries, job creation and destruction appear to be part of the same economic process. Country-specific job creation and destruction rates are positively correlated across industries and this relationship is strong and statistically significant in most cases (Table 2). Put another way, industries that create more jobs also destroy more jobs.

5. The United Kingdom's exception can be explained by the fact that, for this country, comparable gross jobflow data are available only for the manufacturing industry where, as shown in Table 1, the cross-industry variation of excess reallocation is smaller. As a sensitivity analysis, data from Hijzen et al. (2007) were substituted for data presented in this section for the United Kingdom, which resulted in a greater correlation between UK rates and average rates. 
DELSA/ELSA/WD/SEM(2009)23

Figure 1. Country-specific and average industry distributions of gross job reallocation rates

Country-specific rates (by industry) as a function of average rates, by country, 1997-2004
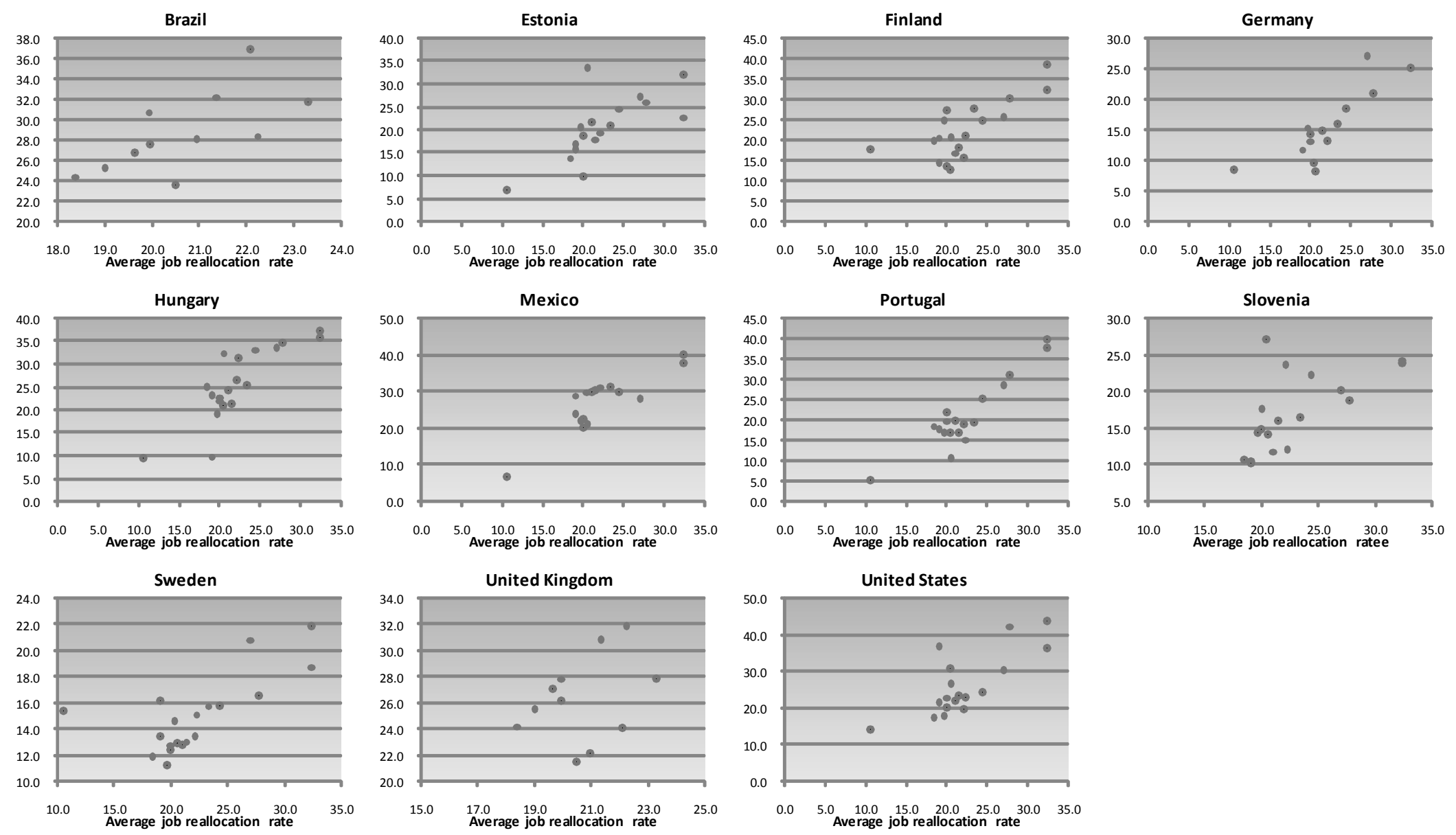

Notes: percentage rates. Brazil: 1998-2000; Estonia: 2003; Germany: 1997-1998; Finland: 1997; Hungary: 1998-2000; Portugal: 1997; Mexico: 2000; Slovenia: 2002-2003; Sweden: 1997-2003; United Kingdom: 1997-1998; United States: 2001-2004. 
Figure 2. Cross-industry correlation of country-specific and average rates of job creation and destruction Correlation coefficients, 1997-2004

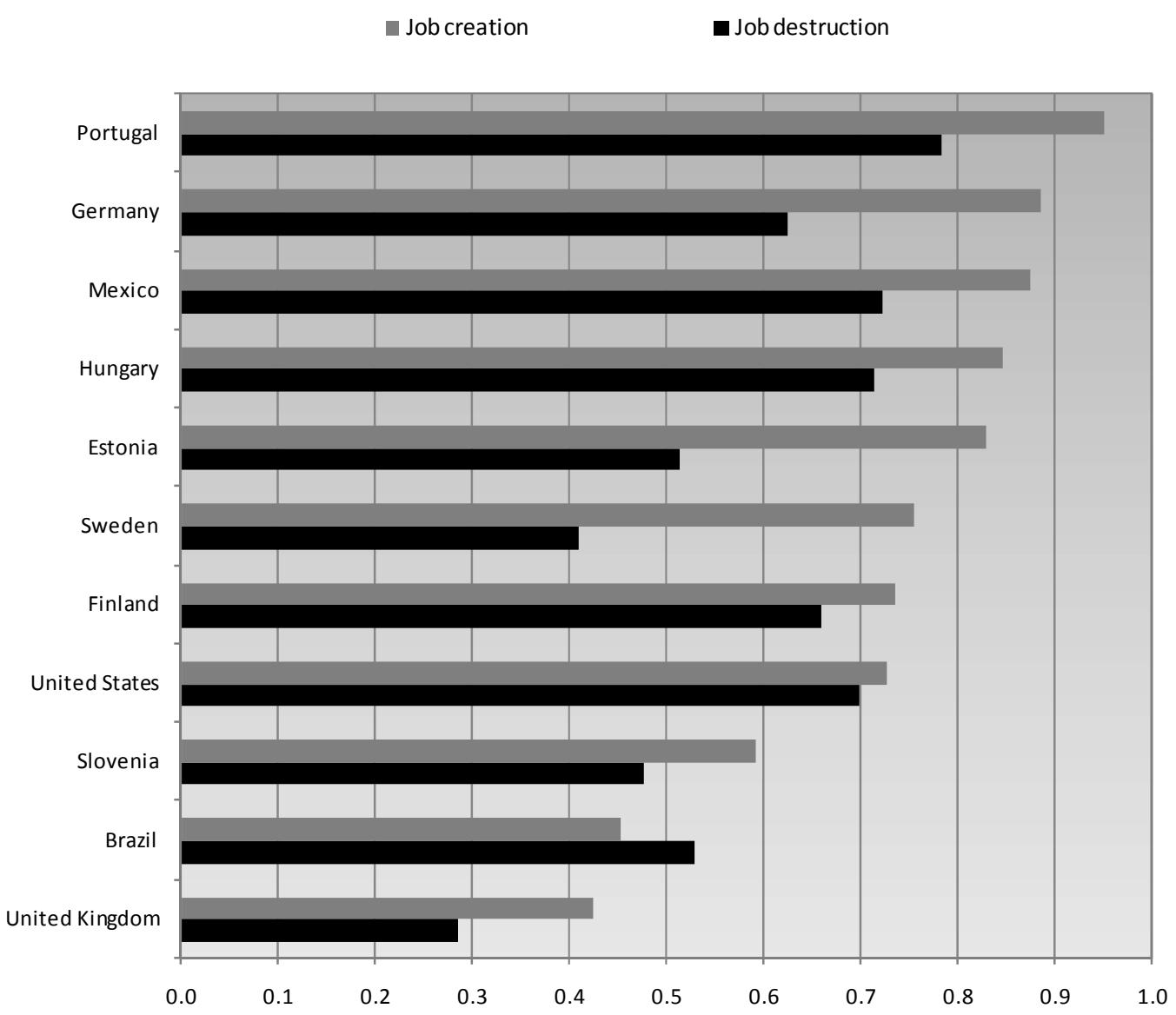

Notes: correlations between country-specific and average industry distributions. Brazil: 1998-2000; Estonia: 2003; Germany: 1997-1998; Finland: 1997; Hungary: 1998-2000; Portugal: 1997; Mexico: 2000; Slovenia: 2002-2003; Sweden: 1997-2003; United Kingdom: 1997-1998; United States: 2001-2004.

Table 2. Within country/cross - industry correlations of job creation and destruction rates

\begin{tabular}{l|c}
\hline \multicolumn{2}{c}{ Correlation coefficients, 1997-2004 } \\
\hline Brazil & 0.682 \\
Estonia & 0.292 \\
Finland & 0.573 \\
Germany & 0.691 \\
Hungary & 0.528 \\
Mexico & 0.658 \\
Portugal & 0.802 \\
Slovenia & 0.193 \\
Sweden & 0.859 \\
United Kingdom & 0.311 \\
United States & 0.857 \\
\hline
\end{tabular}

Note: Correlations between country-specific industry rates. Data refer to: Brazil: 1998-2000; Estonia: 2003; Germany: 1997-98; Finland: 1997; Hungary: 1998-2000; Portugal: 1997; Mexico: 2000; Slovenia: 2002-03; Sweden: 1997-2003; United Kingdom: 1997-98; United States: 2001-04. 
29. These correlations have often been observed in the literature (e.g. Davis et al., 1996, and CoenPirani and Lee, 2007), and are consistent with a variety of theoretical explanations, including those related to the diffusion of demand and technological shocks in industries (e.g. Mortensen and Pissarides, 1994) and differences in life-cycle stages of industries (e.g. Jovanovic, 1982, and Klepper, 1996). According to the first group of theories, positive or negative correlations can emerge depending on the degree of heterogeneity of shocks. Conversely, the second group of theories relates job creation and destruction patterns to differences in the breadth of business opportunities that are available in different industries depending on their life-cycle. Mass entry of firms would occur in industries where technological opportunities are larger, together with a process of fast learning and competitive selection that would generate mass exit and shakeouts (for evidence, see for example, Klepper and Simons, 2005).

30. A simple analysis of variance shows that about $40 \%$ of the cross-country/cross-industry variation in gross job reallocation rates is explained by their cross-industry variation (Table 3). Similarly, industryspecific effects account for about $44 \%$ of the overall variation of job creation rates. However, they explain a much smaller share of job destruction rates $(24 \%)$. The fact that a greater share of the variance is explained by industry effects in the case of job creation rates suggests that industry-specific factors, which apply to all countries, are more important drivers of the creation of jobs than of job destruction. For example, it is likely that rapid worldwide diffusion of technological and organisational changes across competitors in the globalised market and common evolution of global product demand shape the similarity of firms' job creation strategies across countries. Consistent with this interpretation, there appears to be a strong cross-industry correlation between net employment growth, on the one hand, and job creation rates, on the other (Figure 3, Panel A). ${ }^{6}$ In other words, the industries that create more jobs are also those where total employment grows more rapidly. But no such relationship can be found as regards net decreases in employment and job destruction or separation rates (Figure 3, panel B). If anything, the opposite relationship holds. This is probably due to the positive correlation between job creation and destruction.

Table 3. Analysis of variance of cross-country/cross-industry data on gross job flow rates

\begin{tabular}{|c|c|c|c|c|c|c|c|c|}
\hline & \multicolumn{2}{|c|}{ Gross job reallocation } & \multicolumn{2}{|c|}{ Excess job reallocation } & \multicolumn{2}{|c|}{ Job creation } & \multicolumn{2}{|c|}{ Job destruction } \\
\hline Country & 38.0 & $20.83(10)$ & 39.0 & $21.33(10)$ & 30.9 & $15.32(10)$ & 39.2 & $14.66(10)$ \\
\hline Industry & 40.1 & $12.2(18)$ & 39.4 & $11.98(18)$ & 43.8 & $12.04(18)$ & 23.6 & 4.91 (18) \\
\hline Model & 72.5 & $14.19(28)$ & 72.4 & $14.15(28)$ & 69.5 & $12.3(28)$ & 59.6 & $7.96(28)$ \\
\hline
\end{tabular}

Note: The table reports the percentage of the overall variance accounted for by countries, industries or the overall model (that is the percentage explained by the whole regression). F-statistics in italics (with degrees of freedom in parentheses). All components are significant at the $1 \%$ statistical level. As the percentage of the variance explained by each dimension depends on the number of its categories, F-statistics and the ratio of explained variance to the number of degrees of freedom provide information on the relative importance of each dimension. Total number of observations is 180 .

31. Does the fact that country-invariant industry-specific factors have a strong influence on the intensity of job reallocation mean that country-specific factors and policies have only second-order effects on gross job flows? This conclusion would be hasty. While industry distributions appear to be correlated, gross job flows do vary across countries: the cross-country variation can account for a proportion of the overall cross-country/cross-industry variation that is almost as large as that of industry effects - about $30 \%-40 \%$ (Table 3 ) - and almost twice as large in the case of job destruction rates. This finding, therefore suggests that country-specific institutions are likely to play a key role in explaining gross job flows, in

6. Correlations similar to those presented in Figure 3 for the average of the countries for which data are available are found within each country. 
general, and job destruction rates, in particular. Indeed, controlling for industry composition, job flows appear to be greater in the United Kingdom, the United States, Brazil and Mexico, that is in countries with relatively flexible labour markets due to lax employment protection regulations or large informal sectors. In these countries excess job reallocation appears to be at or above $25 \%$ of dependent employment (Table 4). By contrast excess job reallocation rates are below 15\% in continental European countries such as Germany, Slovenia and Sweden. Interestingly, at the country level, no or limited correlation emerge between average net employment growth and job creation or job destruction rates (Figure 4).

Figure 3. Gross job flows and net employment growth, by industry

Average percentage rates, 1997-2004
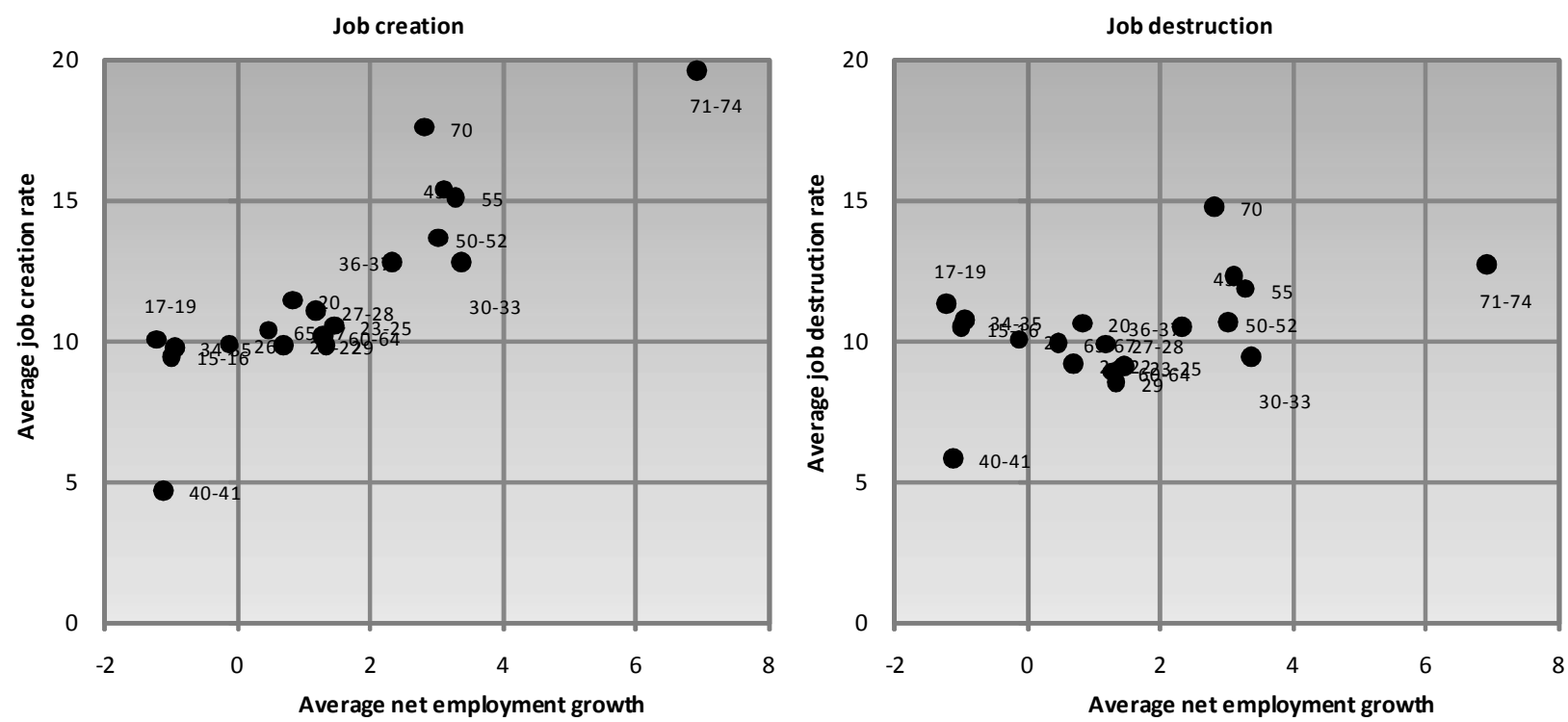

Notes: ISIC rev. 3 codes for industries (see Table 1 for labels). Based on: Brazil: 1998-2000; Estonia: 2003; Germany: 1997-1998; Finland: 1997; Hungary: 1998-2000; Portugal: 1997; Mexico: 2000; Slovenia: 2002-2003; Sweden: 1997-2003; United Kingdom: 1997-1998; United States: 2001-2004.

Table 4. Gross job flows, by country

Job reallocation and excess job reallocation, 1997-2004

Country averages of job reallocation rates expressed in percentages and adjusted by industry composition

\begin{tabular}{l|c|c}
\hline & Job reallocation & Excess job reallocation \\
\hline Brazil & 31.9 & 26.0 \\
Estonia & 21.4 & 17.8 \\
Finland & 23.1 & 17.3 \\
Germany & 16.6 & 14.6 \\
Hungary & 26.9 & 21.2 \\
Mexico & 28.7 & 26.4 \\
Portugal & 23.1 & 18.9 \\
Slovenia & 17.3 & 14.1 \\
Sweden & 15.5 & 14.0 \\
United Kingdom & 30.1 & 27.3 \\
United States & 28.3 & 25.0 \\
\hline
\end{tabular}

Note: Estimated average rates that would be observed in each country if it had the same industry composition of the average country. Brazil: 1998-2000; Estonia: 2003; Germany: 1997-98; Finland: 1997; Hungary: 1998-2000; Portugal: 1997; Mexico: 2000; Slovenia: 2002-03; Sweden: 1997-2003; United Kingdom: 1997-98; United States: 2001-04. 
Figure 4. Job creation, job destruction and net employment growth by country

Percentage rates adjusted by industry composition
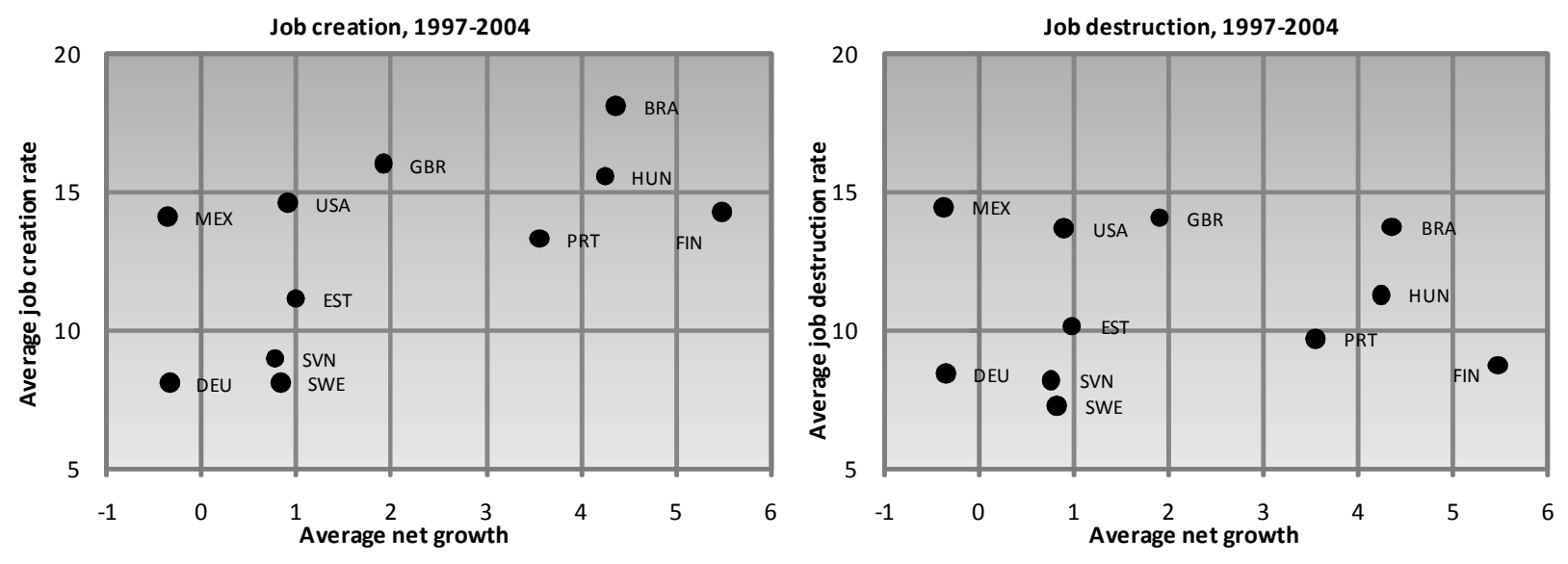

Notes: estimated average rates that would be observed in each country if it had the same industry composition as the average country. Brazil: 1998-2000; Estonia: 2003; Germany: 1997-1998; Finland: 1997; Hungary: 1998-2000; Portugal: 1997; Mexico: 2000; Slovenia: 2002-2003; Sweden: 1997-2003; United Kingdom: 1997-1998; United States: 2001-2004.

32. The finding that there is a significant country effect shaping gross job reallocation rates appears in stark contrast with a common thrust in the literature, which argues, on the basis of anecdotal evidence or casual comparison of country-specific studies, that aggregate worker flows differ across countries but aggregate job flows do not, at least at annual frequency (see for instance Bertola and Rogerson, 1997, Wolfers, 2009, and the literature cited therein). This points to the importance of using harmonised data when drawing cross-country comparisons.

\subsection{Gross worker flows}

33. Are these stylised facts concerning gross job flows mirrored by worker flows? Or do patterns of job and worker flows diverge due to churning flows? Table 5 shows average industry worker flows for the countries for which we have comparable data (see above). ${ }^{7}$ Not surprisingly, the turnover of workers appears to be greater than that of jobs. Annual worker reallocation (i.e. the sum of hirings and separations) averaged across industries, was about $33 \%$ of dependent employment during 2000-2005. Of this, industrylevel excess worker reallocation (i.e. the difference between total worker reallocation in each industry and the absolute value of industry-level net employment growth) was about $30 \%$ of dependent employment at our level of aggregation.

7. In order to preserve comparability with job flows, worker flows presented in this section refer to selfdeclared wage and salary employees aged 15 years or more. However, in order to check that the conclusions drawn in this section are not affected by cross-country/cross-industry differences in the share of part-time working students, as a robustness check we replicated the analysis for the population aged from 25 to 64 years. No remarkable difference emerged but, obviously, flows are smaller. 
Table 5. Average worker reallocation rates, by industry 2000-2005

Average percentage rates

\begin{tabular}{ll|c|c|c}
\hline & \multicolumn{1}{c|}{ Industry } & Excess reallocation & Absolute net growth & Total \\
\hline $15-16$ & Food, beverages and tobacco & 32.1 & 2.8 & 35.0 \\
$17-19$ & Textiles, leather and footwear & 24.0 & 8.1 & 32.2 \\
20 & Wood and manufacturing of wood and cork & 30.6 & 3.7 & 34.3 \\
$21-22$ & Pulp, paper, printing and publishing & 27.1 & 3.3 & 24.9 \\
23 & Coke, refined petroleum and nuclear fuel & 16.0 & 8.9 & 25.3 \\
24 & Chemicals and chemical products & 21.9 & 3.4 & 30.8 \\
25 & Rubber and plastics & 26.6 & 4.2 & 28.4 \\
26 & Other non-metallic mineral products & 24.4 & 4.0 & 28.1 \\
$27-28$ & Basic metals and fabricated metal & 24.3 & 3.8 & 32.5 \\
29 & Machinery, not elsewhere classified & 23.5 & 3.8 & 26.3 \\
$30-33$ & Electrical and optical equipment & 27.4 & 5.1 & 33.3 \\
$34-35$ & Transport equipment & 21.5 & 4.8 & 17.5 \\
$36-37$ & Other manufacturing; Recycling & 29.0 & 4.3 & 37.4 \\
$40-41$ & Electricity, gas and water supply & 13.5 & 4.0 & 33.6 \\
45 & Construction & 41.8 & 3.6 & 46.3 \\
50 & Motor vehicles: sales and repair & 34.0 & 3.0 & 64.7 \\
51 & Wholesale trade, except of motor vehicles & 30.5 & 3.2 & 31.1 \\
52 & Retail Trade, except of motor vehicles & 43.5 & 2.8 & 26.1 \\
55 & Hotels and restaurants & 61.3 & 3.4 & 24.9 \\
$60-63$ & Transport and storage & 28.5 & 2.6 & 35.8 \\
64 & Post and telecommunications & 22.5 & 3.6 & 31.2 \\
$65-67$ & Financial intermediation & 22.2 & 2.7 & 33.0 \\
70 & Real estate activities & 29.9 & 5.9 & 4.5 \\
$71-74$ & Other business services & 36.7 & 4.1 & \\
Average & & 28.9 & & \\
\hline & & & & \\
\hline
\end{tabular}

Note: ISIC rev. 3 codes for industries. Data refer to: Czech Republic: 20025; Ireland: 20003; Norway: 20004; Poland: 20045; Slovak Republic: 20035; Switzerland: 20027; Turkey: 2007; United States, 2000, 2002 and 2004; other countries : 20005.

34. The cross-industry distribution of worker reallocation rates closely resembles that of gross job reallocation. The only exceptions are perhaps the food-processing industry, which has above-average worker flows and low gross job flows, and the hotels and restaurants industry which has much larger worker reallocation than job reallocation, probably because of the large share of seasonal workers and relatively bad working conditions in this industry. Overall, excess worker reallocation varies on average between almost $62 \%$ in the hotels and restaurants industry and $14 \%$ in the electricity, gas and water supply industry.

35. Cross-industry distributions of worker flows appear even more invariant across countries than gross job flow distributions. In fact, in the case of total reallocation, the correlation coefficient with the average distribution is above 0.8 in all but four countries (Figure 5) and it is very high also in the case of separations (Figure 6). In other words, in these countries, the average industry distribution alone can explain more than $60 \%$ of the total within-country cross-industry variation of worker reallocation rates. Not surprisingly, replicating for worker reallocation the same analysis of variance as above, we find that the industry dimension explain a large proportion of the overall variation (from about $37 \%$ for separations to about $51 \%$ for hirings; Table 6 ). 
DELSA/ELSA/WD/SEM(2009)23

Figure 5. Country-specific and average industry distributions of worker reallocation rates

Country-specific rates (by industry) as a function of average rates, by country, 2000-2005

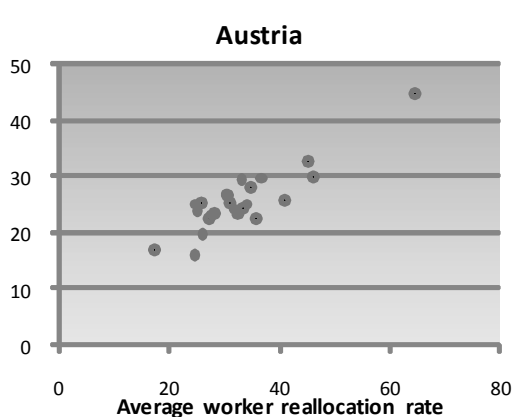

Finland

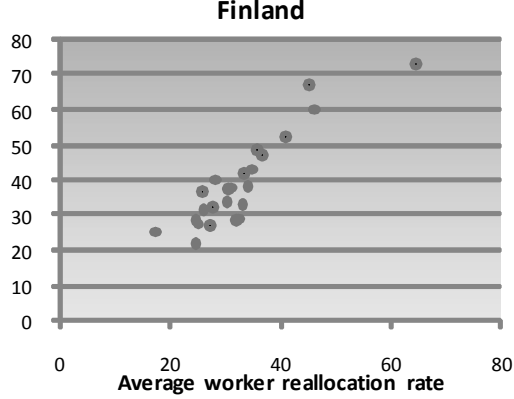

Hungary

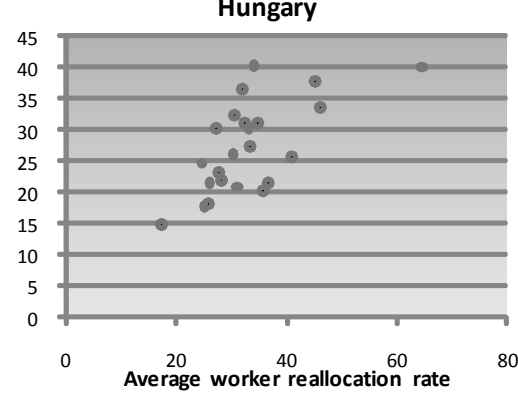

Belgium

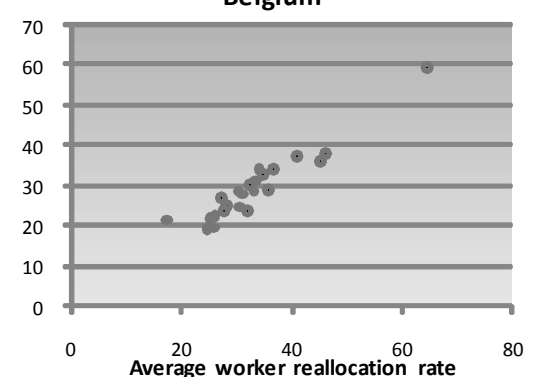

France

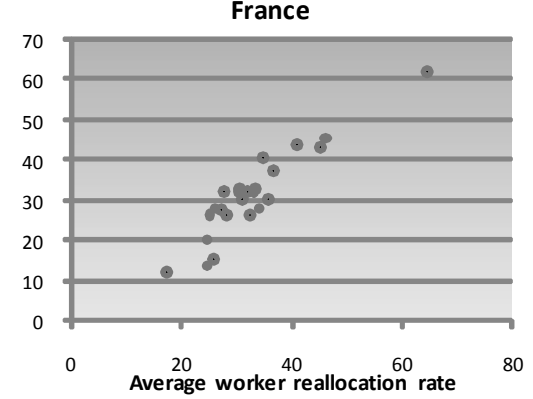

Ireland

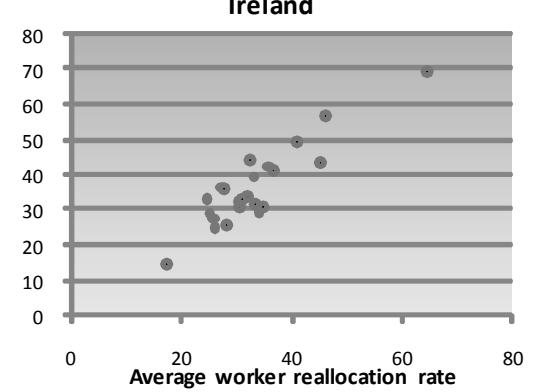

Czech Republic

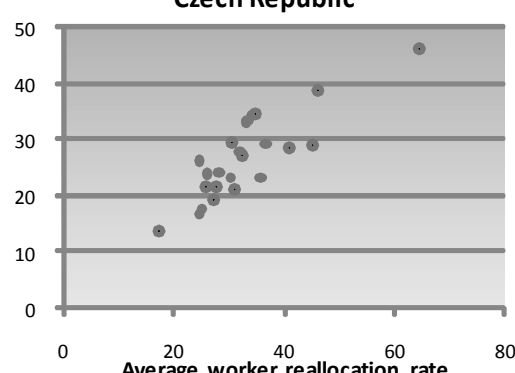

Germany

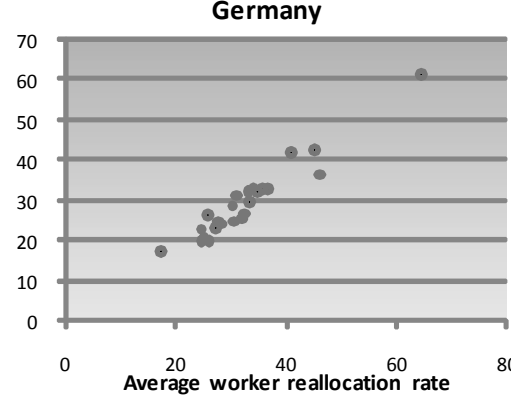

Italy

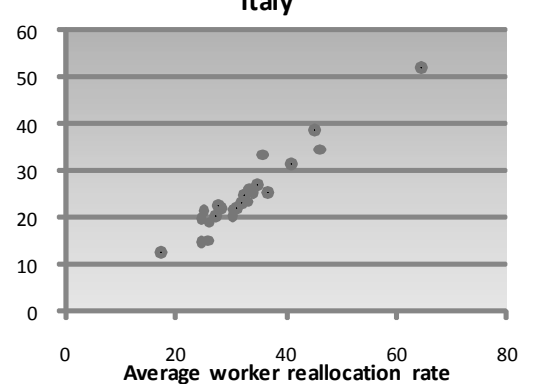

Denmark

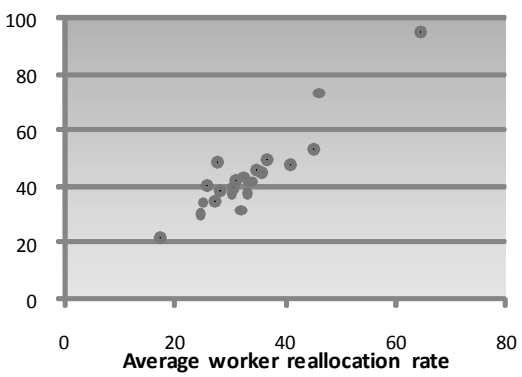

Greece

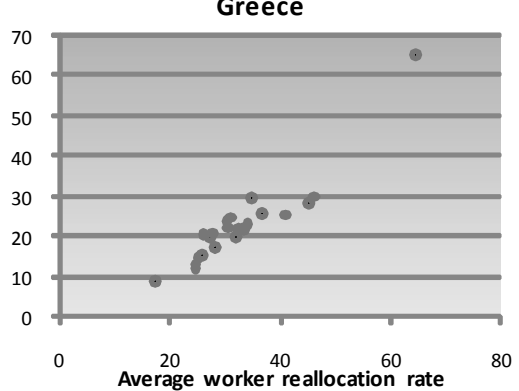

Norway

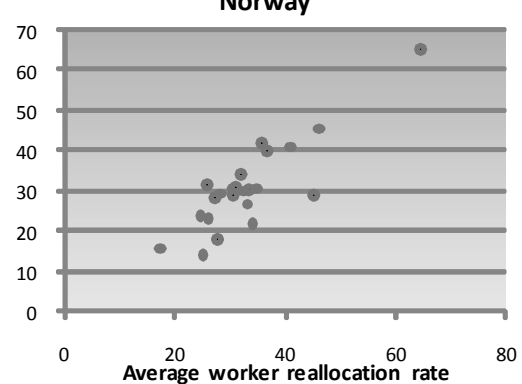


Figure 5. Country-specific and average industry distributions of worker reallocation rates (cont.)

Country-specific rates (by industry) as a function of average rates, by country, 2000-2005

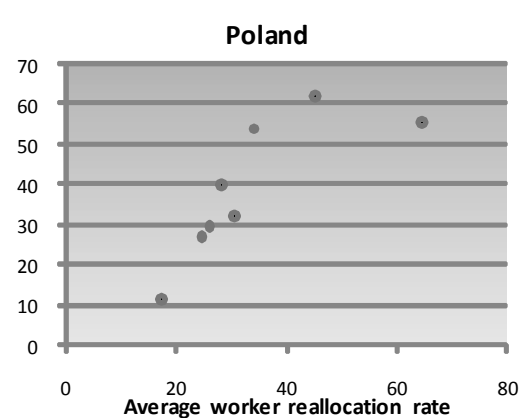

Spain

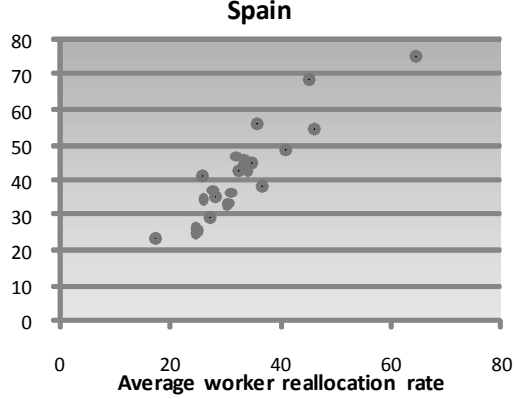

United Kingdom

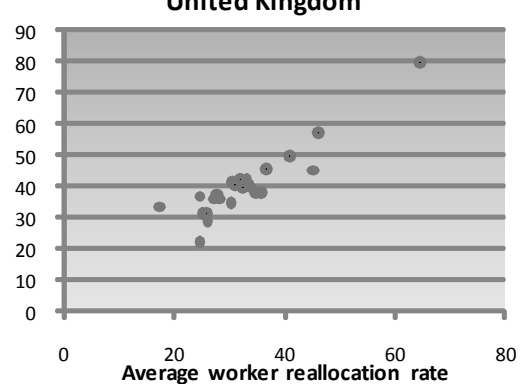

Portugal

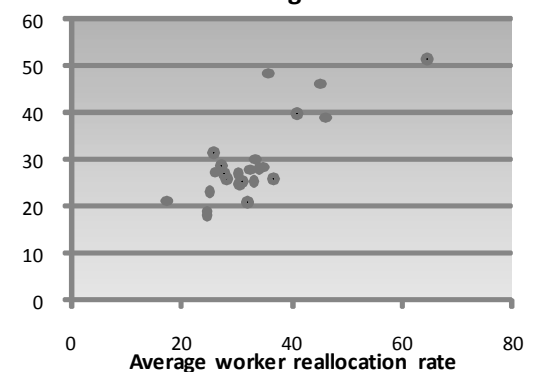

Sweden

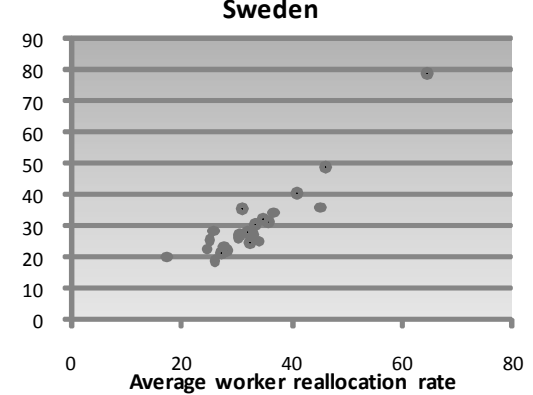

United States

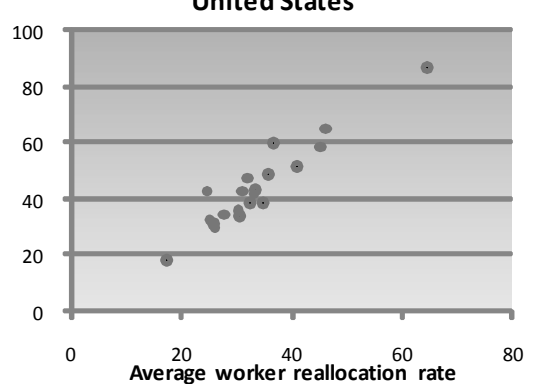

Slovenia

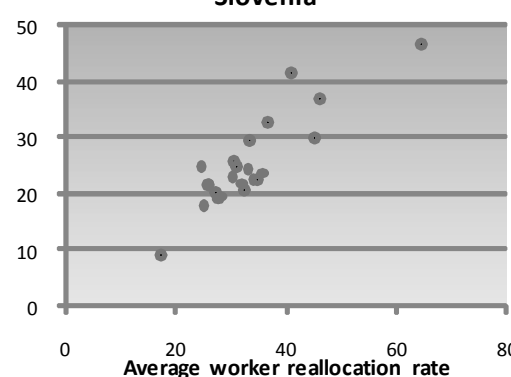

Switzerland

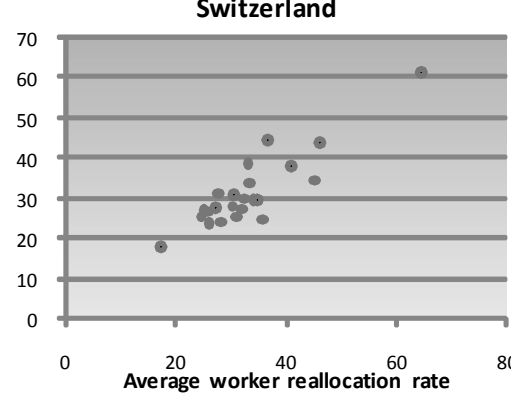

Slovak Republic

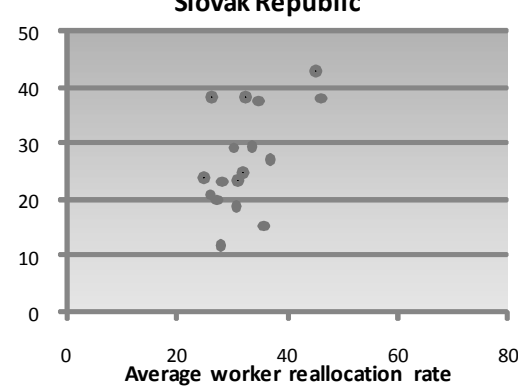

Turkey

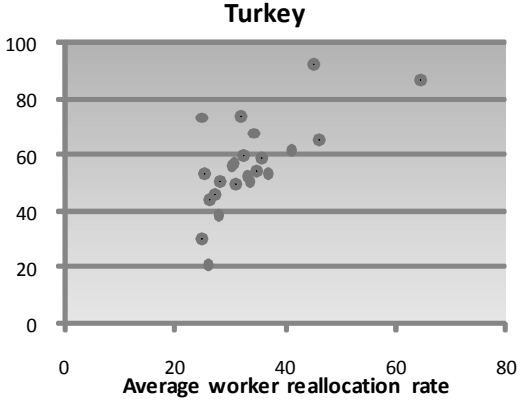

Notes: percentage rates. Austria, Belgium, Denmark, Finland, France, Germany, Greece, Hungary, Italy, Portugal, Slovenia, Spain, Sweden and the United Kingdom: 2000-2005; Czech Republic: 2002-2005; Ireland: 2000-2003; Norway: 2000-2004; Poland: 2004-2005; Slovak Republic: 2003-2005; Switzerland: 2002-2007; Turkey: 2007, United States, 2000, 2002 and 2004 
DELSA/ELSA/WD/SEM(2009)23

Figure 6. Cross-industry correlation of country-specific and average hiring and separation rates

Correlation coefficients, 2000-2005

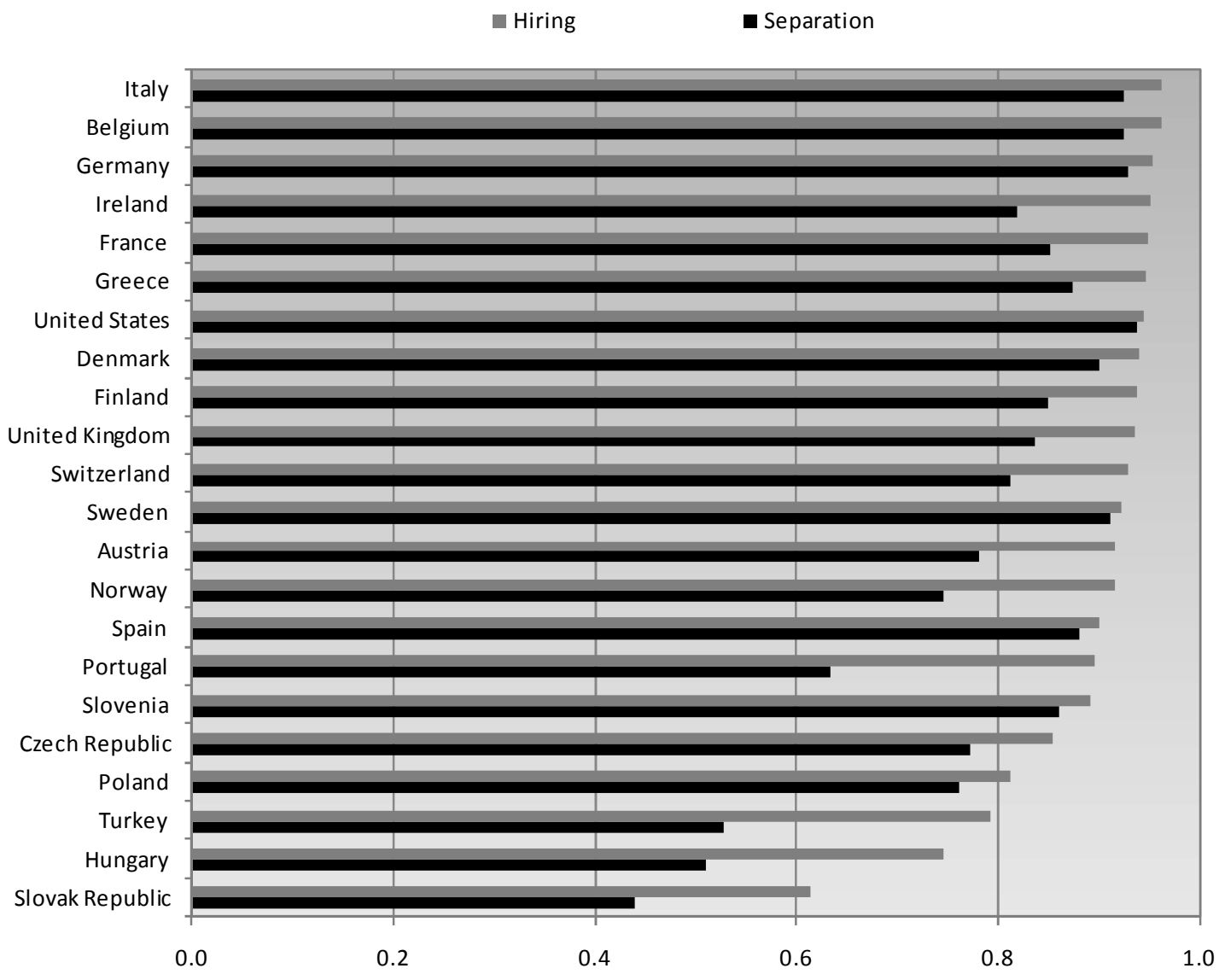

Notes: correlations between country-specific and average industry distributions. Austria, Belgium, Denmark, Finland, France, Germany, Greece, Hungary, Italy, Portugal, Slovenia, Spain, Sweden and the United Kingdom: 2000-2005; Czech Republic: 2002-2005; Ireland: 2000-2003; Norway: 2000-2004; Poland: 2004-2005; Slovak Republic: 2003-2005; Switzerland: 2002-2007; Turkey: 2007, United States, 2000, 2002 and 2004.

Table 6. Analysis of variance of cross-country/cross-industry data on worker flow rates

\begin{tabular}{|c|c|c|c|c|c|c|c|c|}
\hline & \multicolumn{2}{|c|}{ Worker reallocation } & \multicolumn{2}{|c|}{$\begin{array}{c}\text { Excess worker } \\
\text { reallocation }\end{array}$} & \multicolumn{2}{|c|}{ Hirings } & \multicolumn{2}{|c|}{ Separations } \\
\hline Country & 35.0 & $41.37(21)$ & 32.2 & $37.51(21)$ & 32.4 & $46.31(21)$ & 33.3 & $24.9(21)$ \\
\hline Industry & 45.7 & $49.31(23)$ & 48.4 & $51.44(23)$ & 51.4 & 67.04 (23) & 37.2 & 25.44 (23) \\
\hline Model & 82.1 & $46.33(44)$ & 81.8 & $45.45(44)$ & 85.2 & $58.06(44)$ & 71.7 & $25.62(44)$ \\
\hline
\end{tabular}

Note: The table reports the percentage of the overall variance accounted for by countries, industries or the overall model (that is the percentage explained by the whole regression). F-statistics in italics (with degrees of freedom in parentheses). All components are significant at the $1 \%$ statistical level. As the percentage of the variance explained by each dimension depends on the number of its categories, F-statistics and the ratio of explained variance to the number of degrees of freedom provide information on the relative importance of each dimension. Total number of observations is 490 . 
36. Within countries, the correlation coefficient between industry hiring and separation rates is above 0.8 in two-thirds of the countries for which data are available (Table 7) and significant in all but one country (Turkey). As in the case of gross job flows, this fact suggests that industries that hire more workers are also characterised by more separations. Not surprisingly, industry growth and average hiring and separation rates appear to be correlated (Figure 7), suggesting that factors behind industry growth are not only important determinants of job creation and destruction but also of hirings and separations.

Table 7. Within country/cross -industry correlations of hiring and separation rates

\begin{tabular}{l|c}
\hline \multicolumn{2}{c}{ Correlation coefficients, 2000-05 } \\
\hline Austria & 0.54 \\
Belgium & 0.91 \\
Czech Republic & 0.70 \\
Denmark & 0.94 \\
Finland & 0.96 \\
France & 0.91 \\
Germany & 0.89 \\
Greece & 0.91 \\
Hungary & 0.57 \\
Ireland & 0.79 \\
Italy & 0.94 \\
Norway & 0.71 \\
Poland & 0.93 \\
Portugal & 0.91 \\
Slovak Republic & 0.46 \\
Slovenia & 0.82 \\
Spain & 0.94 \\
Sweden & 0.96 \\
Switzerland & 0.86 \\
Turkey & 0.29 \\
United Kingdom & 0.77 \\
United States & 0.95 \\
\hline &
\end{tabular}

Note: Correlations between country-specific industry rates. Czech Republic: 2002-05; Ireland: 2000-03; Norway: 2000-04; Poland: 2004-05; Slovak Republic: 2003-05; Switzerland: 2002-07; Turkey: 2007; United States, 2000,2002 and 2004; other countries : 2000-05. 
Figure 7. Worker flows and net employment growth, by industry

Average percentage rates, 2000-05
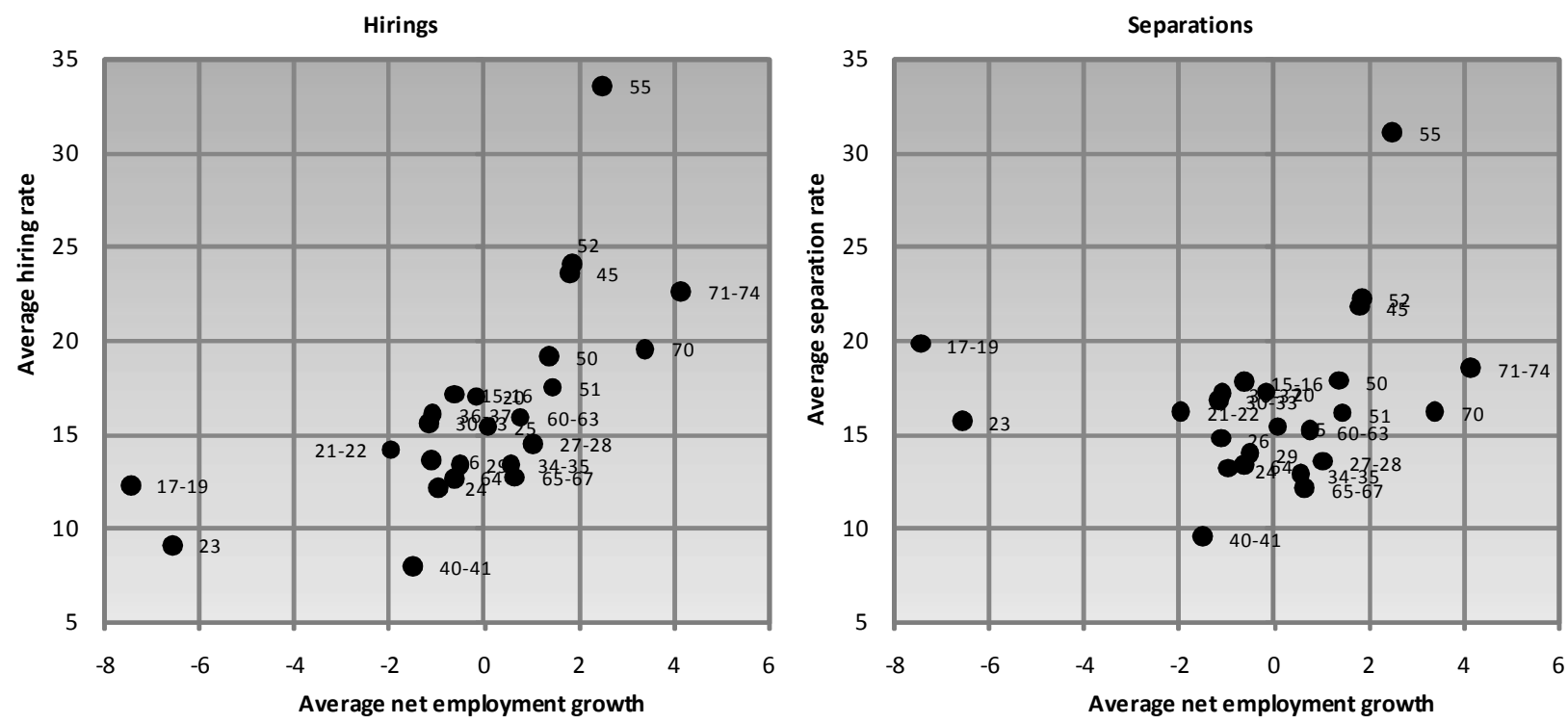

Notes: ISIC rev. 3 codes for industries (see Table 5 for labels). Based on: Austria, Belgium, Denmark, Finland, France, Germany, Greece, Hungary, Italy, Portugal, Slovenia, Spain, Sweden and the United Kingdom: 2000-2005; Czech Republic: 2002-2005; Ireland: 2000-2003; Norway: 2000-2004; Poland: 2004-2005; Slovak Republic: 2003-2005; Switzerland: 2002-2007; Turkey: 2007, United States, 2000, 2002 and 2004.

37. Country effects, nonetheless, explain about one-third of the cross-country/cross-industry variation of worker flows, no matter what measure is considered, suggesting that policy and institutions play an important role in shaping the cross-country distribution of worker flows. As shown in Table 8, total worker reallocation is at or above $40 \%$ in countries with large informal sectors (Turkey), large shares of temporary workers (Finland, Poland, Spain) or relatively flexible regulations for open-ended contracts (Denmark, Ireland, the United Kingdom, the United States). In these countries more than $20 \%$ of the employees separate, at least once, from their employer each year. However, this high rate of mobility out of jobs is matched by comparably high flows of new hires. By contrast, countries with both annual hiring and separation rates below 15\% (such as Austria, the Czech Republic and Greece) have all low shares of temporary contracts or moderate-to-rigid dismissal regulations.

38. Comparing Table 8 with Table 4, it appears that both gross job and worker flows in the most flexible countries in our samples appear to exceed those in the least flexible by at least a factor of two. As hinted at before, this has important implications for theoretical thinking insofar as it suggests that one of the key stylised fact, which the theoretical literature has recently striven to reconcile (see e.g. Pries and Rogerson, 2005, and Koeniger and Prat, 2007), is not a fact: once cross-country comparable data are used, gross worker and job flows appear to show similar levels of cross-country variation. 
Table 8. Worker flows, by country

Worker reallocation and excess worker reallocation, 2000-05

Country averages of worker reallocation rates expressed in percentages and adjusted by industry composition

\begin{tabular}{l|c|c|c|c}
\hline & $\begin{array}{c}\text { Worker } \\
\text { reallocation }\end{array}$ & $\begin{array}{c}\text { Excess worker } \\
\text { reallocation }\end{array}$ & Hirings & Separations \\
\hline Austria & 27.0 & 24.8 & 13.6 & 13.4 \\
Belgium & 32.8 & 30.5 & 16.6 & 16.1 \\
Czech Republic & 29.5 & 26.3 & 14.9 & 14.6 \\
Denmark & 50.0 & 47.4 & 24.9 & 25.1 \\
Finland & 46.3 & 43.7 & 23.6 & 22.7 \\
France & 36.7 & 34.4 & 18.7 & 18.0 \\
Germany & 34.0 & 31.4 & 16.7 & 17.3 \\
Greece & 26.3 & 22.1 & 13.9 & 12.5 \\
Hungary & 28.6 & 23.1 & 15.2 & 13.4 \\
Ireland & 41.7 & 36.4 & 22.1 & 19.5 \\
Italy & 28.5 & 25.5 & 15.3 & 13.2 \\
Norway & 34.4 & 28.4 & 16.5 & 17.9 \\
Poland & 42.9 & 38.8 & 21.6 & 21.3 \\
Portugal & 33.7 & 30.8 & 17.3 & 16.4 \\
Slovak Republic & 32.4 & 25.6 & 16.8 & 15.5 \\
Slovenia & 29.5 & 27.2 & 15.1 & 14.3 \\
Spain & 46.7 & 42.3 & 25.2 & 21.5 \\
Sweden & 36.0 & 33.4 & 18.3 & 17.8 \\
Switzerland & 34.6 & 29.2 & 17.5 & 17.1 \\
Turkey & 59.7 & 52.9 & 32.5 & 27.2 \\
United Kingdom & 45.3 & 42.0 & 22.4 & 22.9 \\
United States & 49.7 & 47.0 & 24.6 & 25.1 \\
\hline & & & &
\end{tabular}

Note: Estimated average rates that would be observed in each country if it had the same industry composition of the average country. Data refer to: Czech Republic: 2002-05; Ireland: 2000-03; Norway: 2000-04; Poland: 2004-05; Slovak Republic: 2003-05; Switzerland: 2002-07; Turkey: 2007; United States, 2000, 2002 and 2004; other countries: 2000-05.

\section{$2.4 \quad$ Churning flows}

39. Gross job and worker flows presented above cannot be directly compared since they refer to different countries and years. An additional reason for caution is that the two sets of flow estimates are based on different data sources: job flows are aggregated from firm-level data, whereas worker flows are obtained from labour force surveys (see Section 2.1 above). Yet, by comparing job and worker flows for the same countries and industries and a limited number of years, one can obtain a rough measure of the degree of labour reallocation which is in excess of that required to accommodate gross job flows that, hence, arises from employers churning workers or workers quitting and being replaced without any change in the total employment of the firm (so-called "churning flows", see Section 1). As far as we know, internationally harmonised data on both job and worker flows have never been exploited so far to investigate churning flows, which makes interesting any rough attempt to analyse them on the basis of cross-country comparable data. We do so by analysing such data for eight countries between 1997 and 2004.

40. For these countries and years, Table 9 shows a decomposition of average industry-level worker reallocation rates into absolute net growth, excess job reallocation and churning rates. On average, $35 \%$ of total worker flows are due to churning, compared with $54 \%$ due to excess job reallocation and the remaining $11 \%$ due to net employment changes at the industry level. Workers employed in hotels and restaurants appear to experience by far the largest mobility due to a large proportion of churning flows 
(56\% of total hirings and separations). Large churning flows appear also at the root of large total worker flows in construction, food processing, and trade. By contrast, in other manufacturing industries, real estate and other professional services, large total flows appear to be mainly due to large job flows. In fact, they appear at the bottom end of the distribution of the ratio of churning flows to total flows, where less than one-third of total flows stem from churning flows. Interestingly, all low-mobility industries - mainly manufacturing - where average excess worker reallocation amounts to less than $25 \%$ of dependent employment can be found in this group.

Table 9. Decomposition of total worker reallocation, by industry

Average industry rates, 1997-2004, in percentage

\begin{tabular}{ll|c|c|c|c}
\hline \multicolumn{1}{c|}{ Industry } & Churning & $\begin{array}{c}\text { Excess job } \\
\text { reallocation }\end{array}$ & $\begin{array}{c}\text { Absolute net } \\
\text { growth }\end{array}$ & Total \\
\hline $15-16$ & Food, beverages and tobacco & 12.9 & 16.5 & 2.2 & 31.6 \\
$17-19$ & Textiles, leather and footwear & 8.4 & 15.1 & 3.7 & 27.3 \\
20 & Wood and manufacturing of wood and cork & 13.0 & 16.6 & 3.0 & 32.6 \\
$21-22$ & Pulp, paper, printing and publishing & 11.3 & 15.8 & 1.8 & 28.9 \\
$23-25$ & Chemical, rubber, plastics and fuel & 9.8 & 15.9 & 1.6 & 27.3 \\
26 & Other non-metallic mineral products & 6.9 & 16.5 & 2.1 & 25.6 \\
$27-28$ & Basic metals and fabricated metal & 7.5 & 16.3 & 2.3 & 26.2 \\
29 & Machinery, not elsewhere classified & 8.7 & 14.9 & 2.7 & 26.3 \\
$30-33$ & Electrical and optical equipment & 8.9 & 16.6 & 4.0 & 29.6 \\
$34-35$ & Transport equipment & 8.0 & 13.2 & 2.5 & 23.7 \\
$36-37$ & Other manufacturing; Recycling & 10.1 & 18.1 & 2.1 & 30.3 \\
$40-41$ & Electricity, gas and water supply & 5.6 & 9.7 & 3.3 & 18.5 \\
45 & Construction & 16.5 & 24.2 & 3.5 & 44.2 \\
$50-52$ & Wholesale and retail trade & 14.0 & 20.4 & 3.3 & 37.7 \\
55 & Hotels and restaurants & 32.1 & 24.3 & 2.8 & 59.3 \\
$60-64$ & Transport, storage and communications & 10.3 & 16.4 & 1.8 & 28.5 \\
$65-67$ & Financial intermediation & 4.2 & 16.1 & 4.0 & 24.3 \\
70 & Real estate activities & 11.2 & 24.6 & 3.5 & 39.4 \\
$71-74$ & Other business services & 11.4 & 24.7 & 6.6 & 42.7 \\
Average & & 11.1 & 17.7 & 3.0 & 31.8 \\
\hline
\end{tabular}

Note: ISIC rev. 3 code for industries. Based on: Germany: 1997-98; Finland: 1997; Hungary: 1998-2000; Portugal: 1997; Slovenia: 2002-03; Sweden: 1997-2003; United Kingdom: 1997-98; United States: 2002 and 2004.

41. Do churning flows differ across countries? Table 10 presents a decomposition of aggregate worker reallocation rates into absolute net growth, excess job reallocation and churning rates, all adjusted by industry composition - that is, the average rates that would be observed if each country had the same industrial structure as the average country - for the eight countries for which it can be computed. Churning flows appears to be remarkably invariant across countries. With the exception of Hungary, where churning flows amount to only $5.2 \%$ of dependent employment, average churning rates appear to vary little across countries, ranging from $12 \%$ to $16.8 \%$ of dependent employment (corresponding, however, to between $30 \%$ and $50 \%$ of total worker reallocation). ${ }^{8}$

8. The little cross-country variation is also confirmed by a simple analysis of variance of the type developed in the previous subsections. While the industry dimension appears to account for $40 \%$ of total crosscountry/cross-industry variance in churning rates, less than $8 \%$ of this variance appears to be explained by the country dimension. 
Table 10. Decomposition of total worker reallocation, by country

Average rates adjusted for industry composition, 1997-2004, in percentage

\begin{tabular}{l|c|c|c|c}
\hline & Churning & $\begin{array}{c}\text { Excess job } \\
\text { reallocation }\end{array}$ & $\begin{array}{c}\text { Absolute net } \\
\text { growth }\end{array}$ & Total \\
\hline Finland & 13.8 & 16.4 & 5.9 & 36.0 \\
Germany & 13.9 & 15.2 & 1.8 & 30.9 \\
Hungary & 5.2 & 21.4 & 5.4 & 32.0 \\
Portugal & 12.0 & 19.7 & 4.9 & 36.6 \\
Slovenia & 12.4 & 14.7 & 3.2 & 30.3 \\
Sweden & 16.8 & 14.5 & 1.5 & 32.7 \\
United Kingdom & 13.1 & 28.3 & 3.0 & 44.4 \\
United States & 15.4 & 29.2 & 2.1 & 46.8 \\
\hline
\end{tabular}

Note: Estimated average rates that would be observed in each country if it had the same industry composition of the average country. Data for the following countries refer to: Germany: 1997-98; Finland: 1997; Hungary: 1998-2000; Portugal: 1997; Slovenia: 2002-03; Sweden: 1997-2003; United Kingdom: 1997-98; United States: 2002 and 2004. Differences from Table 4 are due to differences in the sample.

42. The lack of cross-country variation in churning flows is also mirrored by the insignificant crosscountry/cross-industry correlation between churning and job flows (with a correlation coefficient of 0.07 ). By contrast, if we regress total worker reallocation on total job reallocation (including a constant) in our country/industry sample, we obtain a coefficient estimate of 0.98 , insignificantly different from unity. In other words, a one-percentage-point increase in job reallocation is associated with an equal increase of worker reallocation, with no increase in churning. This finding could reflect the fact that staff increases are obtained by firms by increasing hiring without reducing separations and, vice versa, for staff contractions, as suggested by Burgess et al. (2001) and Davis et al. (2006) who show that, at the firm level, average churning flows in the United States appear to be independent of job flows. In other words factors behind variation of gross job flows across industries and countries are also key determinants of worker flows, suggesting that gross job and worker flows can be used as alternative measures of labour flexibility and, by and large, capture similar phenomena. This is an important findings since worker flow data, when derived from employee and labour force surveys, typically contain much information on workers but little information on firms and vice versa for job flow data that are typically aggregated from enterprise surveys or firm tax files. The next three sections exploit this "equivalence" to dig into firm and worker determinants of labour market dynamics.

\section{Gross job flows by entry and exit of firms}

43. The job-flow statistics presented in the previous section do not distinguish between firm start-ups, shutdowns and reallocation involving continuers - the latter term referring to incumbent firms that are active during the whole reference period, often. Distinguishing among these categories of firms is important because there is evidence that in OECD countries more than $10 \%$ of all firms enter and more than $5 \%$ shut down their operations in an average year. Moreover, in most cases, less than $50 \%$ of entrants survive more than four years (see e.g. Bartelsman et al., 2005). But even though firm churning is large, the average size of both entering and exiting firms is often very small. According to Bartelsman et al. (2009), in all countries for which comparable data are available, the average size of entrants is never greater than $60 \%$ of the average incumbent, and in many OECD countries this figure is as low as $30 \%$. The size of firms shutting down their business operations is often small too (see e.g. Brandt, 2004). What is the relative contribution of firm churning to gross job reallocation? Are the characteristics of gross job flows by entry and exit different from those concerning continuers? In this section we look at these issues by decomposing gross job flows at the industry-level between firm entry and exit. We will then examine continuers in more detail in the next section by resorting to firm-level data. 


\subsection{Data and methodology}

44. Data from Haltiwanger et al. (2006) and Bartelsman (2008), already used in the previous section, report information on job creation and destruction by entry and exit of firms. ${ }^{9}$ Since these flows are, in principle, not affected by the measurement problem discussed above, we can append data from Hijzen et al. (2007) for the United Kingdom that cover also services and a longer period. In addition, for a number of countries (the Czech Republic, Estonia, Finland, Hungary, Italy, the Netherlands and Spain), we can derive job creation by entry and exit for 2005 from employment-weighted firm entry and exit rates and employment levels, reported in the OECD Business Demographics database, and employment growth rates, reported in the EU KLEMS database. In this way we end up with a sample covering 14 countries. As standard in the literature (see Davis and Haltiwanger, 1999, and Haltiwanger et al., 2006), in order to get meaningful economic figures, gross job flow rates by entry and exit are computed by using total dependent employment of each industry at the denominator.

\subsection{Cross-country industry-level evidence}

45. Figure 8 shows that, on average, entry and exit of firms account for about one-third of total job reallocation in the business sector. Cross-industry variation is, however, small: start-ups and shutdowns account for $29 \%$ to $36 \%$ of gross job reallocation in all industries, except in the energy and financial intermediation industries ( $21 \%$ and $26 \%$, respectively). As a consequence industries creating or destroying more jobs also create and destroy more jobs by entry and exit. ${ }^{10}$

\section{Figure 8. Contribution of firm entry and exit to gross job reallocation}

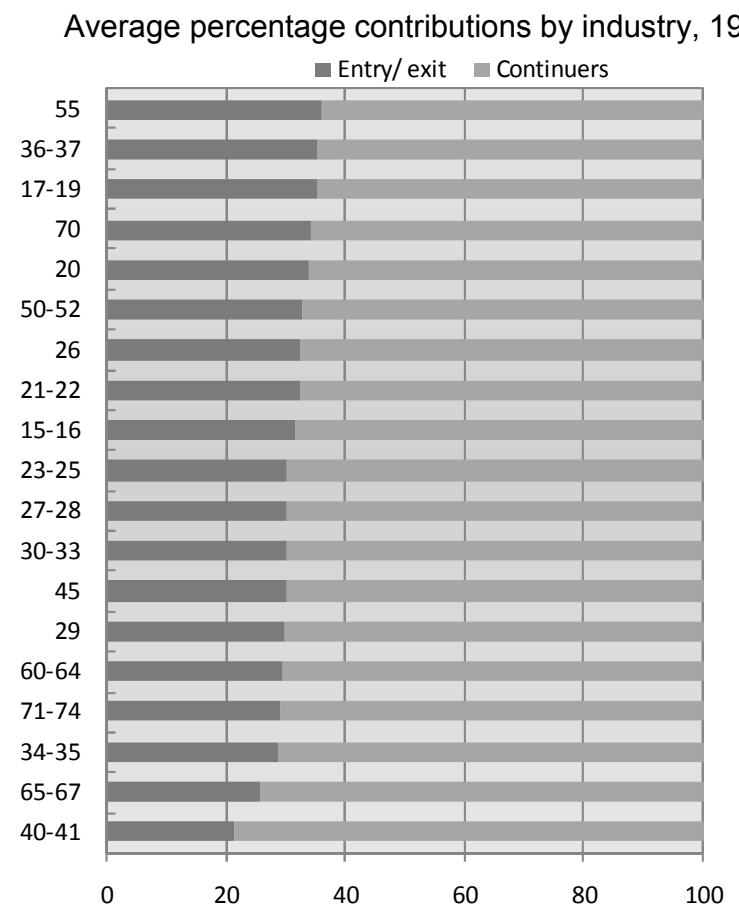

Notes: ISIC rev. 3 codes for industries (see Table 1 for labels). Based on: Brazil: 1998-2000; Estonia: 2003; Germany: 1997-1998; Finland: 1997; Hungary: 1998-2000; Portugal: 1997; Mexico: 2000; Slovenia: 2002-2003; United Kingdom: 1997-1998; United States: 2001-2004.

9. This information does not appear reliable for Sweden. We decided therefore to exclude this country from the analysis of entry and exit.

10. Figure 8 presents the decomposition concerning gross job reallocation. Similar patterns emerge when looking at job creation or job destruction separately. 
46. The distribution of total job creation and destruction within and across countries appears to be remarkably similar to that of job creation and destruction by entry and exit. In particular, industry distributions of job creation and destruction rates by entry and exit are strongly correlated across countries and these correlations are stronger in the case of job creation by entry (Figure 9). With the exception of Finland and Slovenia, industry distributions of job creation by entry are always strongly correlated with the distribution of the average country (with a correlation coefficient above 0.7 ). This correlation is often significant also in the case of job destruction by exit, but the correlation coefficient is smaller in all but three countries. Consistently, a simple analysis of variance shows that the cross-industry variation explains $47 \%$ of the total variance of job creation by entry and a much smaller proportion in the case of job destruction by exit (Table 11). Not surprisingly, we find a mirror picture when we conversely look at gross job flows for continuing firms.

\section{Figure 9. Cross-industry correlation of country-specific and average job creation and destruction rates by} entry and exit

\section{Correlation of country rates with average rates}

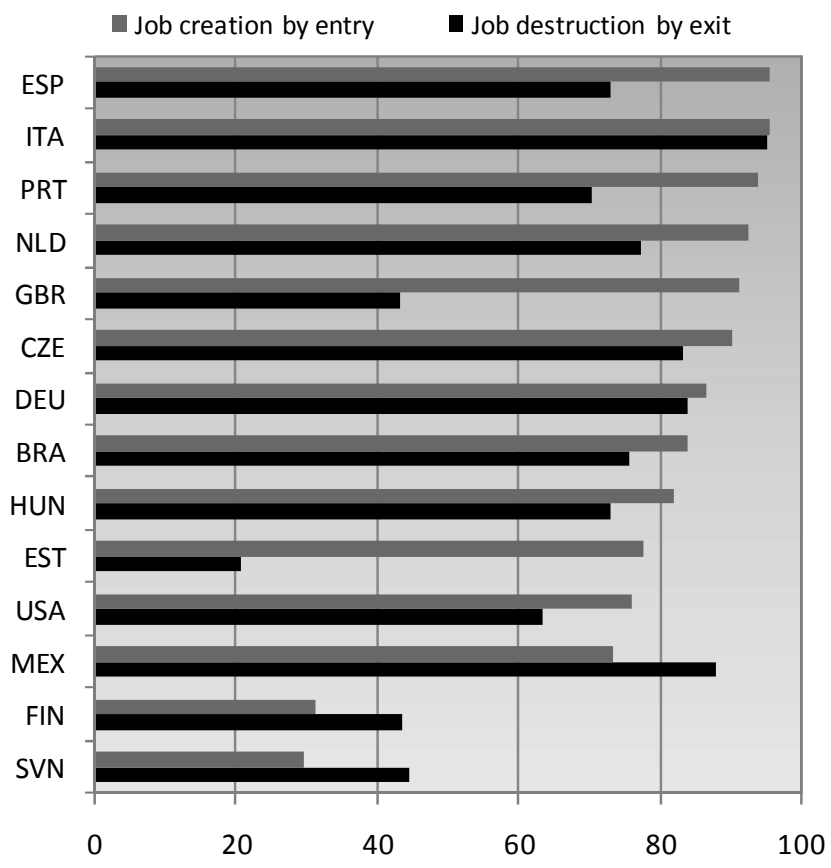

Notes: correlations between country-specific and average industry distributions. Brazil: 1998-2000; Czech republic: 2005; Estonia: 2003 and 2005; Finland: 1997 and 2005; Germany: 1997-1998; Hungary: 1998-2000 and 2005; Italy: 2005; Portugal: 1997; Mexico: 2000; Netherlands: 2005; Slovenia: 2002-2003; Spain: 2005; United Kingdom: 1998-2005; United States: 2001-2004.

Table 11. Analysis of variance of cross-country/cross-industry data on gross job creation and destruction by entry, exit and continuers

\begin{tabular}{lcc|cc|cc|cc}
\hline & \multicolumn{4}{c}{ Entry and exit } & \multicolumn{4}{c}{ Continuers } \\
& \multicolumn{2}{c|}{ Job creation } & \multicolumn{2}{|c|}{ Job destruction } & \multicolumn{2}{|c|}{ Job creation } & \multicolumn{2}{c}{ Job destruction } \\
\cline { 2 - 7 } & & & & & & & & \\
Country & 18.2 & $7.97(13)$ & 26.4 & $8.87(13)$ & 23.6 & $9.62(9)$ & 43.1 & $18.51(9)$ \\
Industry & 46.9 & $14.04(19)$ & 24.6 & $5.65(19)$ & 40.8 & $7.88(19)$ & 21.7 & $4.42(19)$ \\
& & & & & & & & \\
Model & 62.2 & $11.04(32)$ & 50.7 & $6.9(32)$ & 61.9 & $8.11(28)$ & 63.8 & $8.79(28)$ \\
\hline
\end{tabular}

Notes: The table reports the percentage of the overall variance accounted for by countries, industries or the overall model (that is, the percentage explained by the whole regression). F-statistics in italics (with degrees of freedom in parentheses). All components are significant at the $1 \%$ statistical level. As the percentage of the variance explained by each dimension depends on the number of its categories, F-statistics and the ratio of explained variance to the number of degrees of freedom provide information on the relative importance of each dimension. Total number of observations is 248 for entry and exit and 169 for continuers. 
47. By contrast, country-specific factors appear to play a limited role in explaining job creation by firm entry, while they are a key factor affecting job destruction by firm exit (and even more job destruction by continuers). Nevertheless, adjusting for industry composition, reallocation by entry and exit is larger than $9 \%$ of dependent employment in Brazil, Mexico, the United Kingdom and the United States (Table 12). At the other extreme, less than $5 \%$ of all jobs are created or destroyed by entry and exit in the Netherlands. Again job flows in countries at the top of the distribution exceed those at the bottom by a factor of about two.

Table 12. Job reallocation due to firm entry and exit, by country

Percentage rates adjusted by industry composition, 1997-2005

\begin{tabular}{l|c|c|c}
\hline & $\begin{array}{c}\text { Job creation by } \\
\text { entry }\end{array}$ & $\begin{array}{c}\text { Job destruction by } \\
\text { exit }\end{array}$ & Total \\
\hline Brazil & 6.0 & 5.0 & 11.0 \\
Czech Republic & 3.9 & 4.5 & 8.4 \\
Estonia & 2.3 & 3.7 & 6.0 \\
Finland & 3.9 & 3.1 & 7.0 \\
Germany & 3.2 & 2.2 & 5.4 \\
Hungary & 4.7 & 3.9 & 8.6 \\
Italy & 3.0 & 2.6 & 5.7 \\
Mexico & 5.5 & 4.2 & 9.7 \\
Netherlands & 1.6 & 2.8 & 4.4 \\
Portugal & 4.1 & 3.9 & 8.0 \\
Slovenia & 2.4 & 2.9 & 5.3 \\
Spain & 3.9 & 3.1 & 7.0 \\
United Kingdom & 5.1 & 7.2 & 12.2 \\
United States & 4.6 & 4.8 & 9.4 \\
\hline
\end{tabular}

Note: Estimated average rates of job creation and destruction by entry and exit to total dependent employment that would be observed in each country if it had the same industry composition as the average country. Brazil: 1998-2000; Czech republic: 2005; Estonia: 2003 and 2005; Finland: 1997 and 2005; Germany: 1997-98; Hungary: 1998-2000 and 2005; Italy: 2005; Portugal: 1997; Mexico: 2000; Netherlands: 2005; Slovenia: 2002-03; Spain: 2005; United Kingdom: 1998-05; United States: $2001-04$.

48. Finally, industries that create more jobs by entry also destroy more jobs by exit: at the industrylevel, the within-country correlation between job creation rates by entry and job destruction by exit is significant in most countries (Figure 10, Panel A). But a more blurred picture emerges for continuers. There is a significantly positive industry-level correlation between job creation and destruction by continuers in less than half of the countries (Figure 10, Panel B), and in all but two countries the correlation coefficient is substantially smaller than in the case of entry and exit. This correlation coefficient can even be negative (in Slovenia and the United Kingdom). This suggests that the reason why industries that create more jobs also destroy more jobs is essentially related to the fact that firm entry and exit rates are positively correlated across industries, as predicted by theories of firm learning and industry life-cycles (see above). By contrast, the characteristics of job-creating and job-destroying continuers appear more dissimilar. In the next subsection we dig deeper into this issue by looking at how this relationship changes when data are broken further by firm age and size. 
Figure 10. Within country/cross - industry correlations of job creation and destruction rates
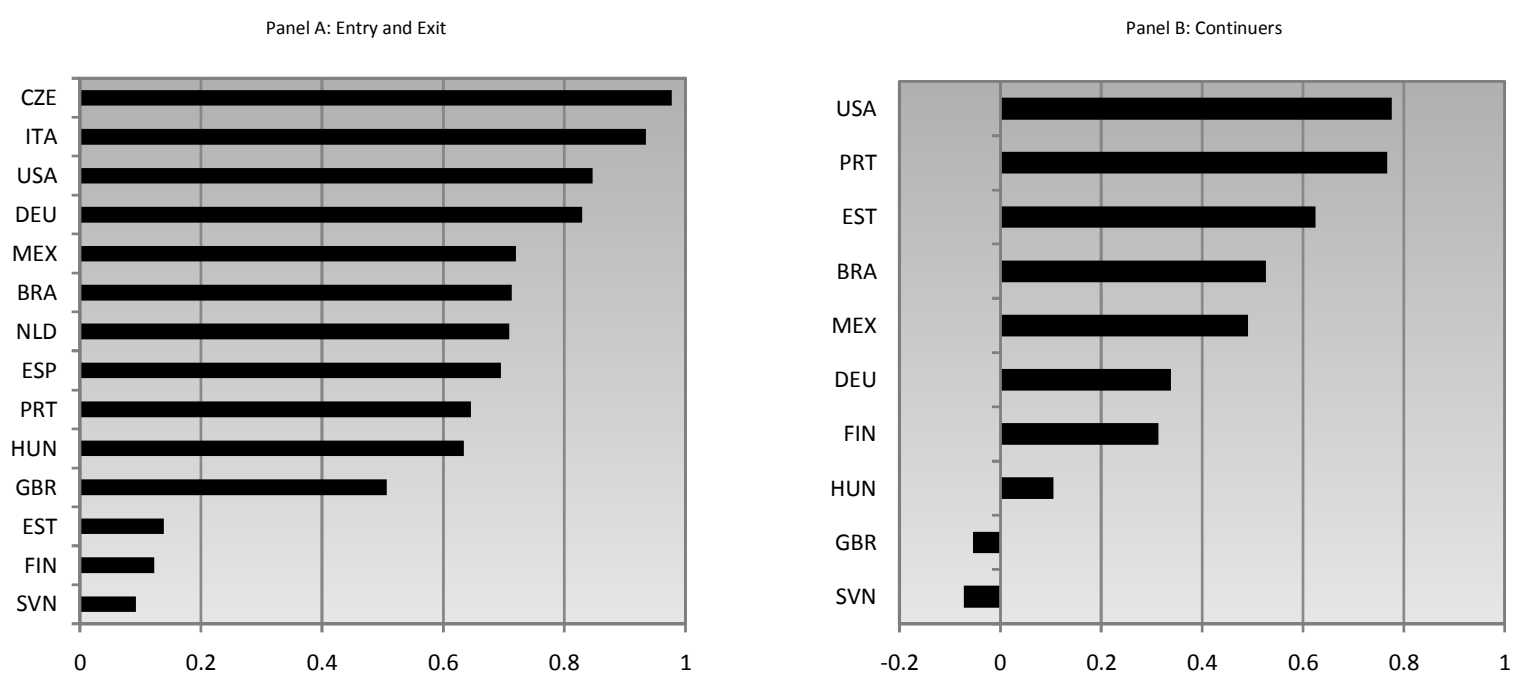

Notes: correlations between country-specific industry rates. Panel A: Brazil: 1998-2000; Czech republic: 2005; Estonia: 2003 and 2005; Finland: 1997 and 2005; Germany: 1997-1998; Hungary: 1998-2000 and 2005; Italy: 2005; Portugal: 1997; Mexico: 2000; Netherlands: 2005; Slovenia: 2002-2003; Spain: 2005; United Kingdom: 1998-2005; United States: 2001-2004. Panel B: Brazil: 1998-2000; Estonia: 2003; Germany: 1997-1998; Finland: 1997; Hungary: 1998-2000; Portugal: 1997; Mexico: 2000; Slovenia: 2002-2003; United Kingdom: 1997-1998; United States: 2001-2004.

\section{Firm-level evidence on gross job flows: the case of medium and large continuers}

49. Two key dimensions of a firm are strongly associated with the magnitude of its job flows: size and age (see e.g. Davis et al., 1996). The importance of the size dimension has been particularly stressed for entrants and shutdowns: firm entry and exit - and the associated creation and destruction of jobs - are highly concentrated among small businesses, which is reflected in a negative relationship between job turnover (job creation and destruction) and firm size. However, a similar relationship appears to hold also for continuers (see e.g. Haltiwanger et al., 2006). Similarly, young establishments create and destroy more jobs, according to several US studies (e.g. Davis et al., 1996, and Faberman, 2003, 2007). The relationship between job destruction and age, nevertheless, appears to be essentially related to the fact that the probability of exiting declines as an establishment ages, suggesting that young firms follow a "up-or-out" pattern with very rapid net growth for survivors balanced by a very high exit rate (Acs et al., 1999; Faberman, 2007; Haltiwanger et al., 2008). Consistent with these findings, using data on continuing firms for 13 European countries, Gomez Salvador et al. (2004), find no declining relationship, on average, between job destruction and firm age.

50. The effects of firm size and age on job reallocation have rarely been studied simultaneously. Two notable exceptions are Acs et al. (1999) and Gomez Salvador et al. (2004). The former look at establishment age and size in the United States and find that establishment age is a more important determinant than establishment average or initial size in determining both job creation and destruction. The latter use broad firm size and age classes in a European multi-country study of institutional determinants of gross job flows and find that both firm age and size are significant co-variates of gross job flows, together with selected institutions.

51. As firms are typically small at birth and then grow if they survive the initial harsh market test, there is a strong correlation between firm age and size, so that their effects on job flows could easily be confounded. Does the commonly-observed relationship between larger firm size and lower job reallocation simply reflect the fact that job creation declines with age? And, what is the relationship between firm age 
and job destruction, once the effect of size is controlled for? In this section, we use internationally harmonised firm-level micro-data for continuing firms in 11 OECD countries to look at these issues. We also exploit the availability of productivity data at the firm level to examine the covariation of job flows and productivity once the effect of size and age has been controlled for.

\subsection{Data and methodology}

52. We use firm-level data from the August 2006 edition of the Amadeus database for European countries and the August 2008 edition of the Orbis database for the non-European countries. Both databases are produced by Bureau van Dijk, a private consultancy company, using and harmonising national databases concerning publicly-available firm-level accounting data. We focus on firms with unconsolidated data. Limited financial account data are used for the United States, where there is no obligation for the firm to publish its accounts. As, in these data, it is not possible to identify firms' closures from firms that exit the sample for other reasons and very young firms are under-represented due to lags in the publication of accounts for start-ups, these data are suitable only for the analysis of continuers.

53. We analyse firm-level patterns of job creation in three ways. First, we aggregate data on gross job flows in cells defined on the basis of the interaction of various firm characteristics (such as industry, size and age) and look at how these characteristics simultaneously influence job creation and destruction.

54. Second, we look in more detail at the impact of specific characteristics (such as age or firm size) on firm-level patterns of job creation and destruction once other observable characteristics have been controlled for. In order to do so, we regress firm-level job creation (or destruction) on several characteristics using the following specification:

$$
J_{\text {igisat }}=\alpha+\lambda_{g} D_{g}+\lambda_{j} D_{j}+\lambda_{s} D_{s}+\lambda_{a} D_{a}+\lambda_{t} D_{t}+\varepsilon_{i}
$$

where $J$ stands for the job-creation (job-destruction) rate, defined at the firm level $i, \alpha$ is a constant, $\varepsilon$ is a standard error term and $D$ s stand for a series of dummies (with coefficient $\lambda \mathrm{s}$ ) to be estimated, including for detailed geographical area $g$ (corresponding to the first two digits of the zip code), detailed industry $j$ (two digits of the ISIC rev. 3 classification), detailed firm-size class $s$ (20-29 employees, 30-39 employees and so on with a range of ten employee for each class, up to 300 employees, then a range of 25 employees for each class up to 500, then 50 up to 700, then 100 up to 1000 , plus one category for 1000 employees or more), ${ }^{11}$ firm age $a$, measured in years, and the calendar year $t$. In the case of the analysis of job flows as a function of firm size, the sum of firm size coefficients is further constrained to be equal to the average jobcreation (job-destruction) rate. Conversely, when patterns by firm age are studied, the sum of firm-age coefficients is imposed to be equal to the average job-flow rate. To the extent that the sample of firms is representative of the population of firms in a country, coefficients of age dummies and firm-size classes that are estimated in this way represent estimated average rates once the effect of other co-variates has been controlled for.

55. Third, we look at the co-variation of firm-level net employment growth and productivity once other observable characteristics have been controlled for. More precisely, we simultaneously regress both productivity measures and changes in log employment levels on the covariates indicated above (that is we fit the same model as above but substituting log employment levels and productivity for job creation rates) and examine the correlation amongst residuals.

56. As employment levels are usually memo items only in firms' financial statements, these data contain a lot of noise. In particular, implausibly large employment changes are sometimes observable

11. We exclude firms with less than 20 employees due to data quality (see below). 
(probably resulting from unreported changes in the measurement unit). Also long sequences of no changes might result from the fact that the same approximated employment level is reported for many years. For example, in certain cases a firm with 1345 employees the first year, 1450 the second year and 1418 the third year is reported as having 1400 employees in all the three years. We therefore try to exclude steadily constant or implausibly large employment changes that can simply be the result of this type of measurement error. When available, we use information on the wage bill to trace out these problems. First, we restrict the sample to firms-by-year observations where employment growth data are available also for either the preceding or the following year (a minimum of three consecutive years with non-missing employment data is therefore required for each firm). Second, we exclude observations with one of the following characteristics: i) no employment change in the current, preceding and following years (or with missing employment growth in one of these years and zero growth in the other two); ii) employment changes greater than 1000 units and percentage log employment growth greater than $50 \%$, both in absolute terms; and iii) absolute percentage log employment growth greater than $60 \%$. Two other exclusion criteria are applied to observations with non-missing employment growth data in the current, preceding and following years: iv) percentage log employment growth greater than $30 \%$ and smaller than $-20 \%$ in two consecutive years accompanied by changes in the wage bill with opposite sign; and $v$ ) percentage log employment growth greater than $40 \%$ and smaller than $-30 \%$ in two consecutive years. Three additional exclusion criteria, which substitute for $i v$ ) and $v$ ) above, are applied at the extremes of a firm spell of nonmissing employment data: $v i$ ) absolute percentage log employment growth greater than $50 \%$ and absolute changes in log employment growth greater than 80 percentage points in the current or following year; vii) percentage log employment growth greater than $30 \%$ and absolute changes in log employment growth greater than 30 percentage points in the current or following year and log employment growth 1.5 times greater than (or opposite sign of) wage bill growth in the current year; and viii) percentage log employment growth smaller than $-20 \%$ and absolute changes in log employment growth greater than 30 percentage points in the current or following year and log employment growth 1.5 times greater than (or opposite sign of) wage bill growth in the current year. For each country, years with too few valid observations per industry are also excluded. As a consequence, data cover only : Belgium (2000-04), Denmark (2001-05), Finland (2002-04), France (2000-04), Italy (2002-03), Japan (2004-06), Poland (2001-04), Spain (2001-04), Sweden (2000-05), the United Kingdom (2000-04) and the United States (2005-06). Obviously these filters are somewhat arbitrary and might introduce biases in measured job flows and the direction of the bias is unknown, a priori, but biases are likely to be larger in unadjusted data.

57. The distribution of firms in the Amadeus and Orbis datasets, however, does not match the economy-wide distribution of firms in the population. This is due to the fact that large firms and specific industries (such as the banking industry in the United States) are over-represented. In particular, since small firms are severely under-represented in these data, only firms with on average 20 employees or more are included in our analysis (we will call these firms medium and large firms hereafter). As a consequence, our empirical results must be treated with some caution since we exclude the class of firms that is typically reported to have the greatest job creation and destruction (although usually through entry and exit, see above for references). When data are aggregated by cells, we also use population weights by firm size and detailed industry - obtained from Eurostat's Structural Business Statistics for European countries, the Establishment and Enterprise Census for Japan and the OECD Firm-level database for the United States to obtain aggregate job flow rates. Aggregate data are also averaged across years, in order to smooth out fluctuations that can simply be the result of measurement error.

58. We also use information concerning true firm population weights to obtain a more representative sample of firm-level data on which we estimate equations such as [6]. Following Schwellnus and Arnold (2008), the sample of each country and year is stratified by firm-size classes and detailed industry, for which the actual distribution of firms is available from the sources described above. Then firms are randomly drawn from each stratum, with the number of observations being calibrated to ensure that the distribution of firms in the sample matches the distribution of the population. In order to use the maximum 
available information, all available firms are drawn from the stratum that is the most under-represented in the raw data, according to the information available on the population of firms. From each other stratum, the number of firms in the sample is set at a level that keeps the ratio between the number of firms in the sample and in the population constant across strata. At the end of the sampling procedure, more than 350000 firms are retained. The same procedure is simultaneously applied to employment and MFP (or value added per worker) data when the objective is estimating the correlation of employment growth and productivity. ${ }^{12}$

\subsection{Patterns of gross job reallocation across groups of continuers}

59. Firm age appears to be unambiguously a key determinant of job creation, at least excluding the smallest firms as well as shutdowns. We group firms that have similar characteristics in terms of country, industry, firm size and age classes into cells, using three size classes and two age classes. ${ }^{13}$ The simple average difference between firms younger and older than 20 years accounts for about $21 \%$ of the total variance, in the case of job creation rates, and about $13 \%$ in the case of overall job reallocation. Variation across firm-size classes that is unrelated with age appears to play a smaller role. Only $4 \%$ of the variation of job reallocation by country, industry, size and age appears to be due to differences across the three firmsize classes considered here. Age and size swap their roles when we look at excess job reallocation, suggesting that the close relationship between age and firm growth is a key determinant of the relationship between age and total job reallocation. The age dimension appears to play also a more limited role for job destruction than for job creation (less than $2 \%$ of the variance in job destruction is explained by this dimension). This suggests that job destruction patterns of medium and large firms vary with their age either less systematically or in a way that is not homogenous across countries, industries and size classes.

Table 13. Analysis of variance of job-flow data for medium and large continuing firms across countries, industries, firm size classes and firm age classes

\begin{tabular}{|c|c|c|c|c|c|c|c|c|}
\hline & \multicolumn{2}{|c|}{ Job reallocation } & \multicolumn{2}{|c|}{ Excess job reallocation } & \multicolumn{2}{|c|}{ Job creation } & \multicolumn{2}{|c|}{ Job destruction } \\
\hline Country & 31.6 & $80.1(10)$ & 25.0 & $48.7(10)$ & 26.1 & $64.5(10)$ & 25.7 & $42.0(10)$ \\
\hline Industry & 12.1 & $15.4(20)$ & 8.5 & $8.3(20)$ & 12.1 & $15.0(20)$ & 11.5 & $9.4(20)$ \\
\hline Size & 3.7 & $46.8(2)$ & 11.4 & $111.1(2)$ & 2.4 & $29.1(2)$ & 1.1 & $8.8(2)$ \\
\hline Age & 12.5 & $317.6(1)$ & 2.2 & $43.4(1)$ & 20.7 & $510.0(1)$ & 1.6 & $25.7(1)$ \\
\hline Model & 60.2 & $46.3(33)$ & 48.1 & $28.4(33)$ & 59.0 & 44.1 (33) & 38.3 & $19.0(33)$ \\
\hline
\end{tabular}

Notes: Underlying data are aggregated in cells by country, industry, firm size classes and firm age classes. The table reports the percentage of the overall variance accounted for by countries, industries or the overall model (that is the percentage explained by the whole regression). F-statistics in italics (with degrees of freedom in parentheses). All components are significant at the $1 \%$ statistical level. As the percentage of the variance explained by each dimension depends on the number of its categories, F-statistics and the ratio of explained variance to the number of degrees of freedom provide information on the relative importance of each dimension. Firm size is divided in three classes: 20-49 employees, 50-99 employees and 100 employees or more; firm age is divided in 2 classes: less than 20 years and 20 years or more. Firms with less than 20 employees are excluded. Data refer to continuers with published accounting data. Total number of observations is 1044 .

12. Following Schwellnus and Arnold (2008), MFP data are constructed by regression at the detailed country and industry-level value added per worker on the capital labour ratio.

13. 20-49 employees, 50-99 employees and 100 employees or more; and less than 20 years, and 20 years or more - that is approximately less than the sample mean and more than the sample mean. 
60. On the other hand, the inclusion of age and size considerably reduces the importance of the industry dimension as well. In sharp contrast with the previous section, the industry dimension appears to account for about $10 \%$ of the variance only. This fact holds independently of the job flow measure used. ${ }^{14}$ By contrast, about one-fourth of the total variance is still accounted for by cross-country differences, which is comparable to what found in Section 2, pointing again to the substantial cross-country variation of gross job flows. ${ }^{15}$ This notwithstanding, distributions of job reallocation rates over industry, firm-size and age classes appear to be closely correlated across countries, with correlation coefficients varying between 0.52 - for the United States - and 0.86 - for Finland (Figure 11). ${ }^{16}$

61. The patterns revealed in Table 13 might mask further composition effects. For instance, one might conjecture that, within each country, more dynamic geographical areas, where business opportunities are wider, create more jobs and are characterized by greater firm entry and, therefore, smaller firm size and younger firms. To what extent is the covariation between firm age and job creation simply due to regional disparities within countries? In order to answer these questions, Panels A and B of Figure 12 present average firm-level job creation and job destruction rates, respectively, as a function of firm size, by country, controlling for firm age and detailed industry and geographical area. Figure 13 does the same for detailed firm age, including detailed firm-size classes as additional control. Note, however, that the precision of the estimates is a function of the number of observations in each country. The dispersion of the distribution within narrowly defined firm-size or age classes, therefore, is not fully comparable across countries. In fact, this dispersion appears systematically greater in Poland, Denmark or the United States, where the sample contains less than 15000 valid observations, and is smaller in France and Spain, where sample size exceeds 90000 observations. ${ }^{17}$

62. In all countries for which we have data, once small firms are excluded from the sample and firm age and geographical location are controlled for, the firm-size profile of the job creation and destruction rates of continuers is essentially flat or slightly declining (Figure 12). By contrast, job creation rates decline significantly with age even controlling for size and location (Figure 13). With the exceptions of Denmark, France, and Sweden, job creation rates decline by six percentage points or more between the second and the sixtieth year of firm life (conditional on survival and other characteristics) ${ }^{18}$ The decline of job creation, as the firm ages, appears to be steeper when the firm is young and then gradually flattens out. By contrast, job destruction rates rise with firm age in some countries but, in general, the relationship is weaker and the curve is essentially horizontal in many others. The increase in job destruction with age is particularly steep in Japan, Poland and the United States. In these three countries, conditional on survival, and controlling for other characteristics, firms aged from fifty to sixty years tend to destroy, as a percentage of their own employment, twice as many jobs as firms about five years after birth. This relationship appears, on the contrary, particularly flat in France and Italy.

14. A qualitatively similar finding is reported by Haltiwanger et al. (2006) upon the inclusion of the size dimension in a sample spanning over all firms.

15. Remember that data used in this section come from thoroughly different sources from those used in Section 2. Therefore our finding on cross-country variations is unlikely to be due to source-specific biases.

16. It must be noted that rates presented in this section are not comparable with those presented in the previous section insofar as only employment of continuers with 20 employees or more is used in the denominator, due to data availability.

17. Sample size by country is as follows (calendar years in parentheses): Belgium: 33867 (2000-2004); Denmark: 14673 (2001-2005); France: 116152 (2000-2004); Italy: 28281 (2002-2003); Japan: 26669 (2004-2006); Poland: 8726 (2001-2004); Spain: 93306 (2001-2004), Sweden: 31700 (2000-2005); the United Kingdom: 40968 (2000-2004); the United States: 14482 (2005-2006). Although included in Table 13, with less than 7000 valid observations, Finland is excluded from this exercise.

18. Firms aged one year or less are excluded. 
DELSA/ELSA/WD/SEM(2009)23

Figure 11. Country-specific and average job reallocation rates, by industry, firm-size and firm-age

Country-specific rates as a function of average rates, by country, 2000-2006
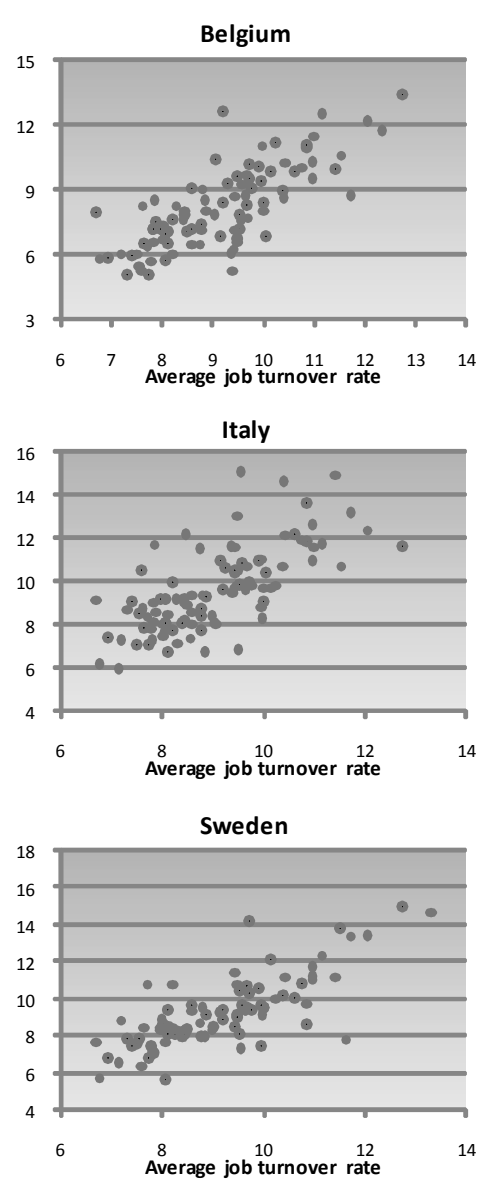

Denmark

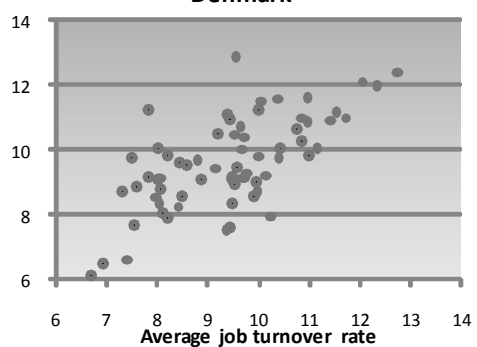

Japan

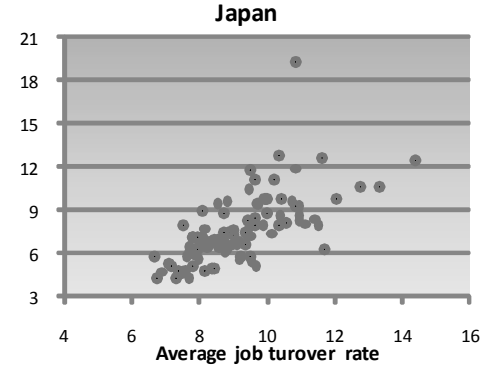

United Kingdom

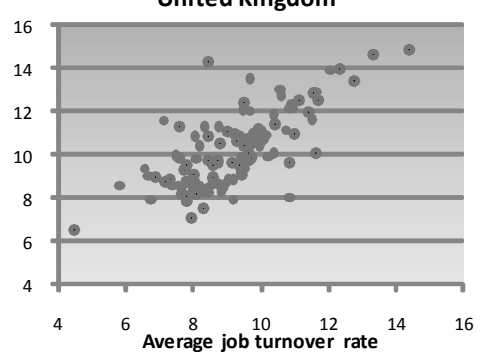

Finland

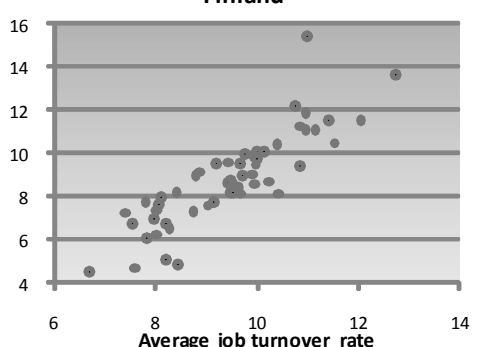

Poland

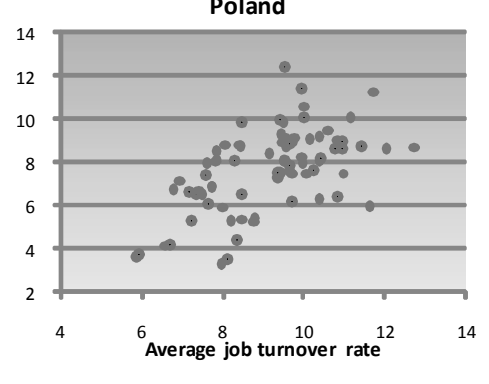

United States

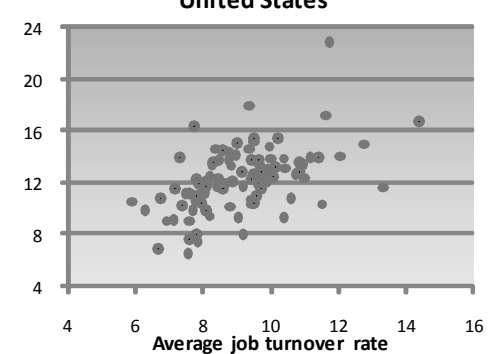

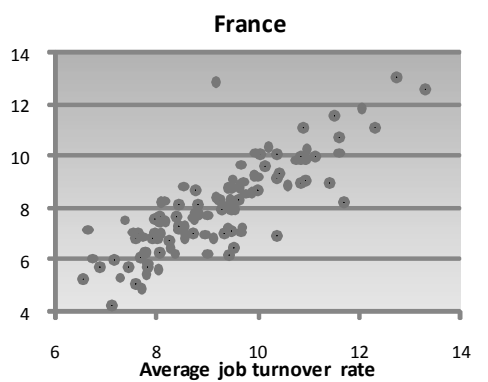

Spain

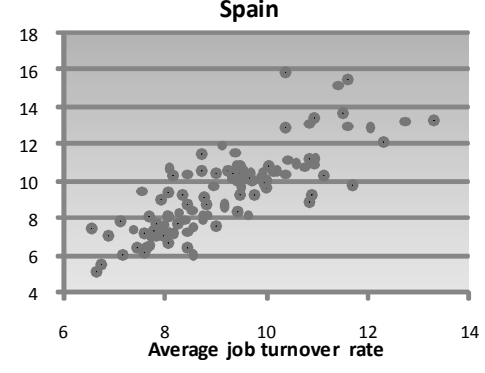

Notes: percentage rates. Data-points refer to job reallocation rates by industry, firm size classes and firm age classes. 21 industries partitioning the non-farm business sector are considered. Firm size is divided in three classes: 20-49 employees, 50-99 employees and 100 employees or more; firm age is divided in 2 classes: less than 20 years and 20 years or more. Firms with less than 20 employees are excluded. Data refer to continuing firms with published accounting data. Belgium, 2000-2004, Denmark, 2001-2005, Finland, 2002-2004, France, 2000-2004, Italy, 2002-2003, Japan, 2004-2006, Poland, 2001-2004, Spain, 2001-2004, Sweden, 2000-2005, the United Kingdom, 2000-2004, and the United States , 2005-2006. 
Figure 12. Job creation and destruction as a function of firm-size

Average rates adjusted by firm-age, industry, region and year, by country, 2000-2006

Belgium

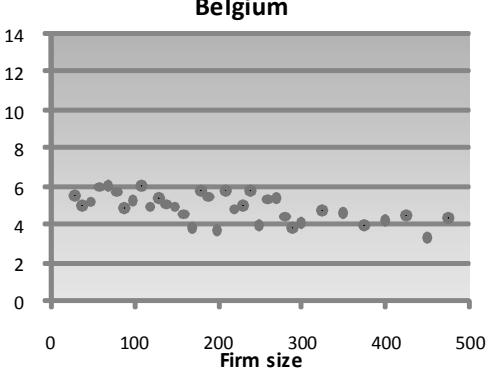

Japan

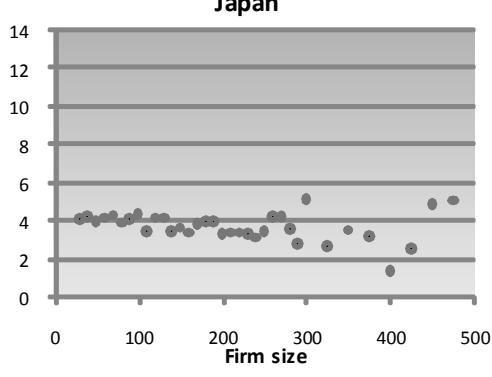

United Kingdom

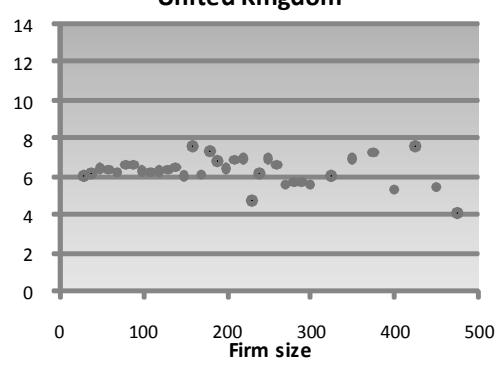

Panel A. Job creation

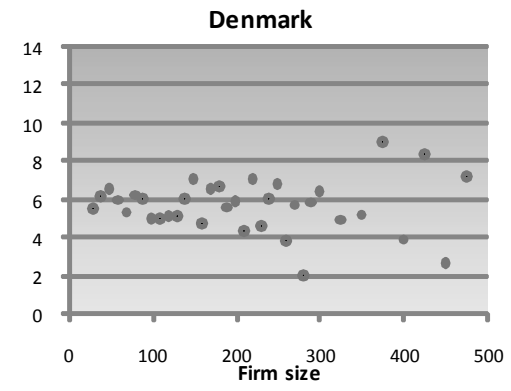

Poland
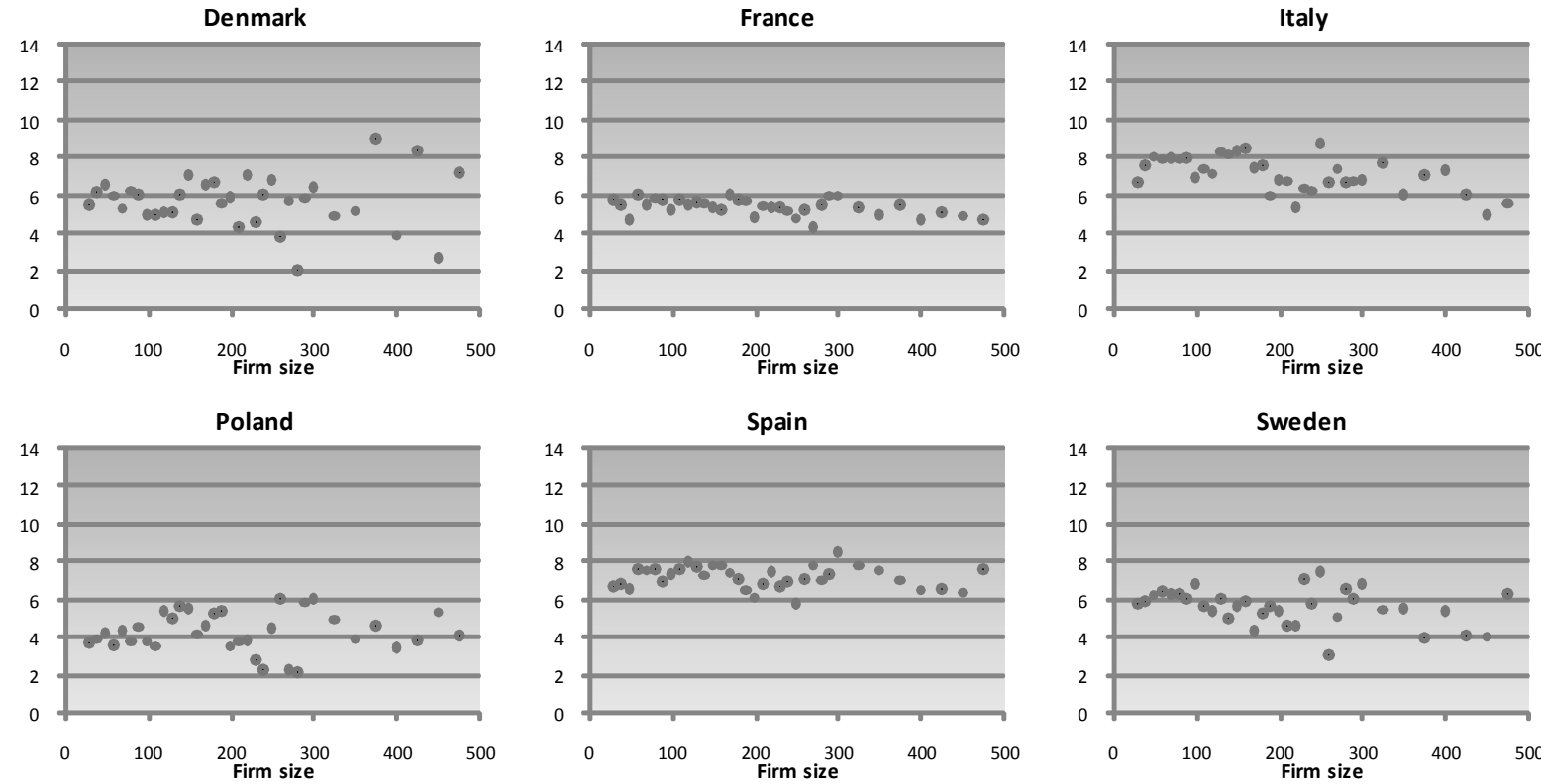

Spain
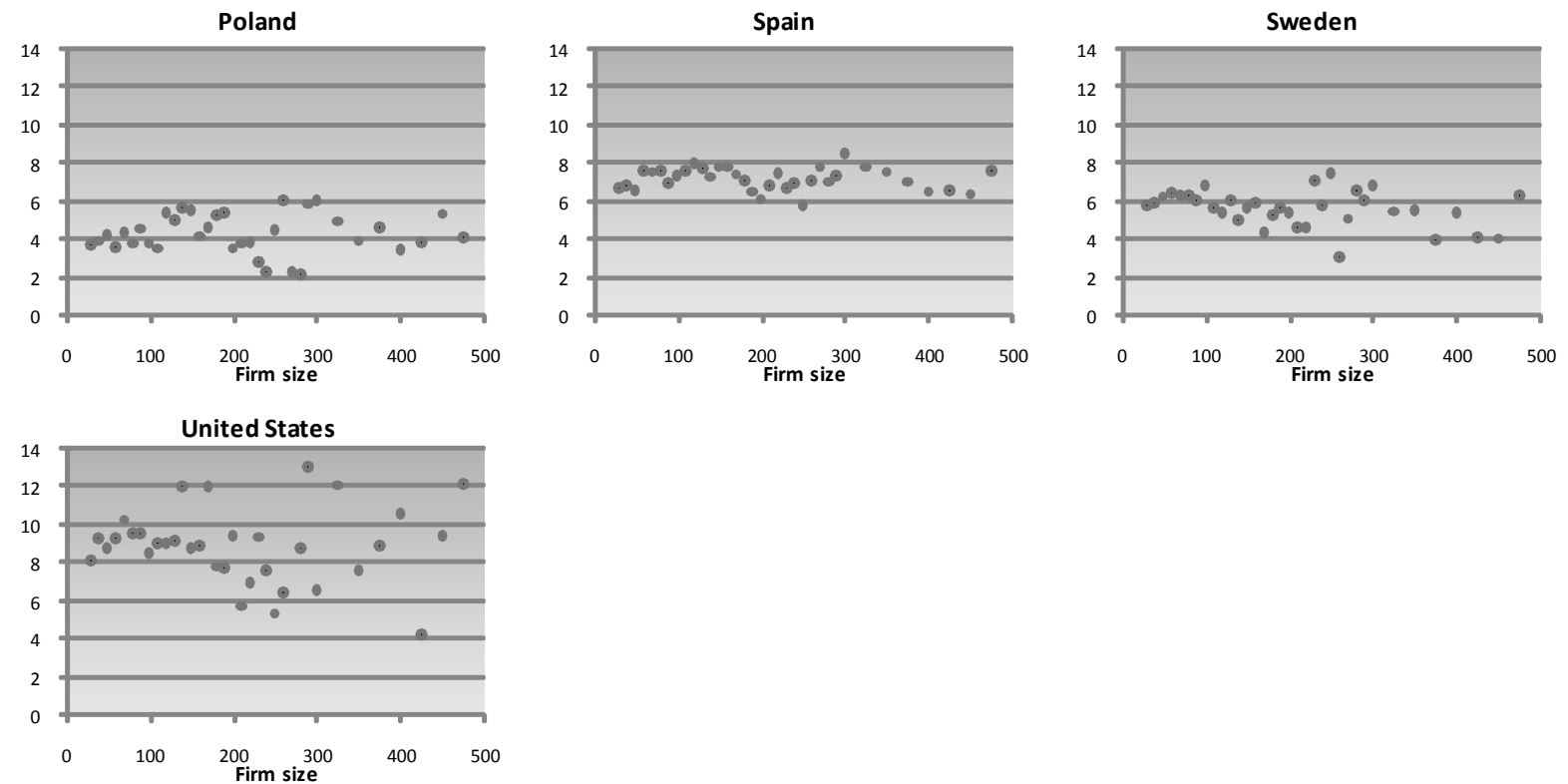
Figure 12. Job creation and destruction as a function of firm-size (cont.)

Average rates adjusted by firm-age, industry, region and year, by country, 2000-2006

Belgium

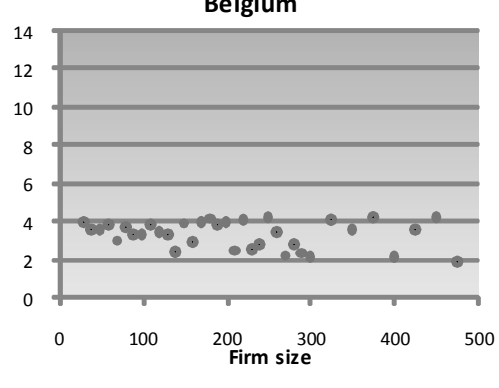

Japan
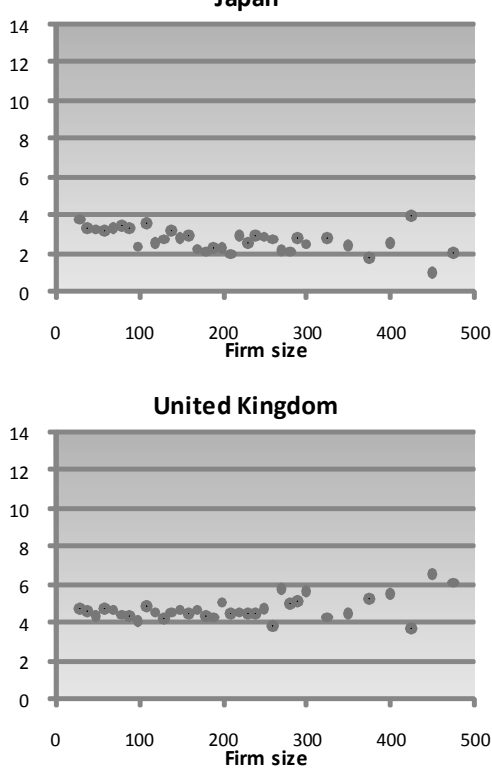

Panel B. Job destruction

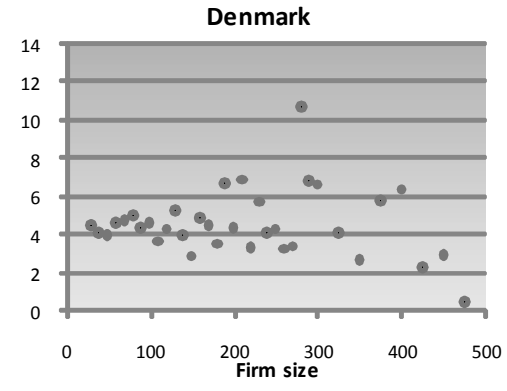

Poland
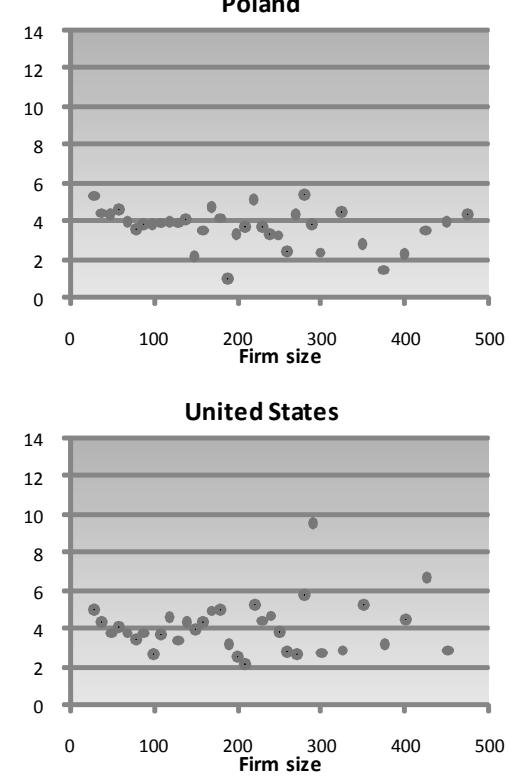

France

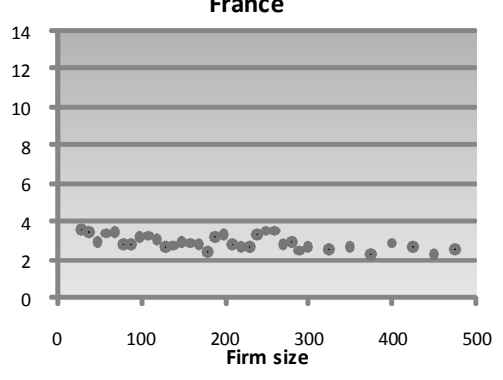

Spain

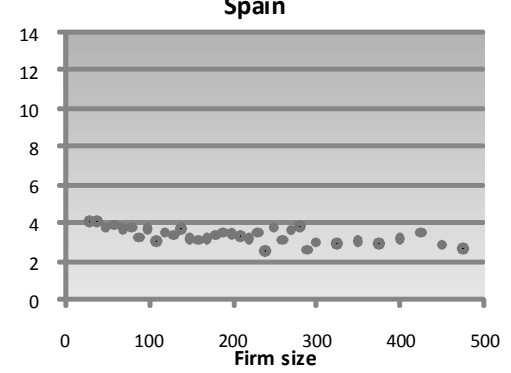

Italy
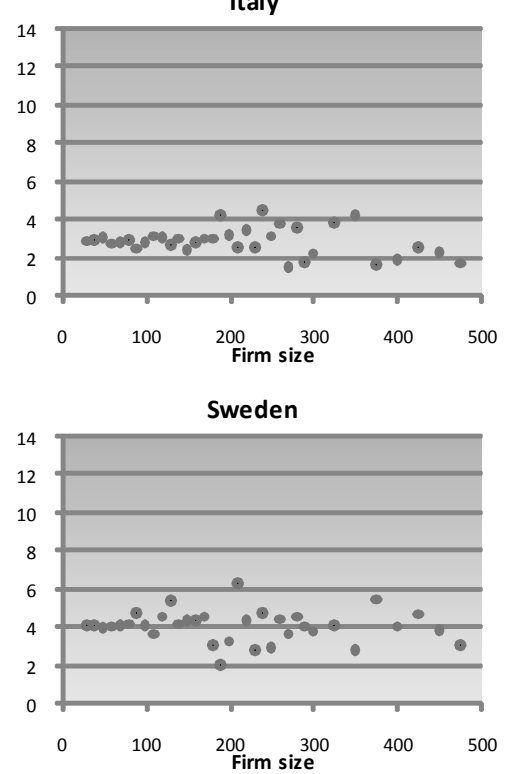

Notes: Firms with less than 20 employees are excluded and aged less than 2 years are excluded. Points located at the class barycenter. Rates for firms with more than 500 employees are not shown. Belgium, 2000-04; Denmark, 2001-05; France, 2000-04; Italy, 2002-03; Japan, 2004-06; Poland, 2001-04; Spain, 2001-04; Sweden, 2000-05; the United Kingdom, 2000-04; and the United States, 2005-06. 
Figure 13. Job creation and destruction as a function of age

Average percentage rates adjusted by firm-size, industry, region and year, by country, 2000-2006

Belgium

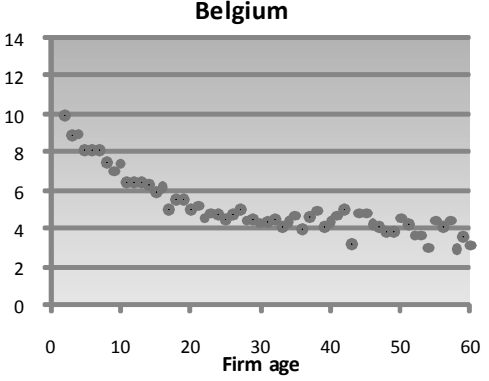

Japan

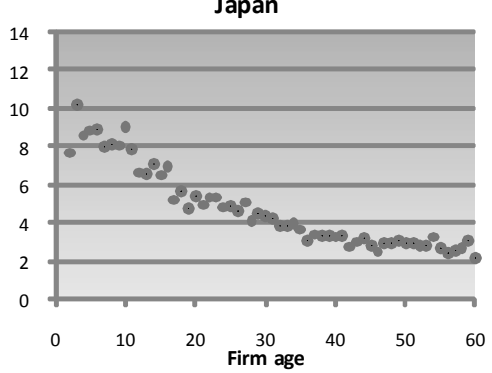

United Kingdom

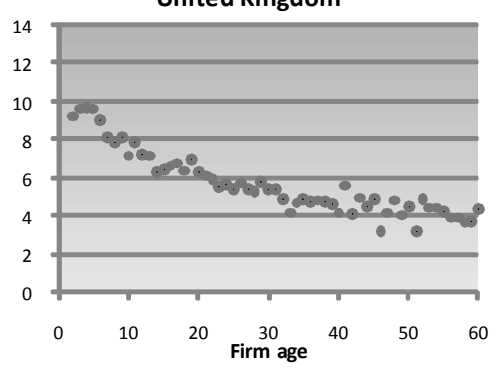

Panel A. Job creation

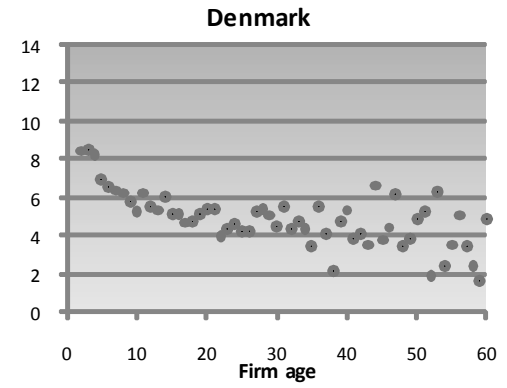

Poland
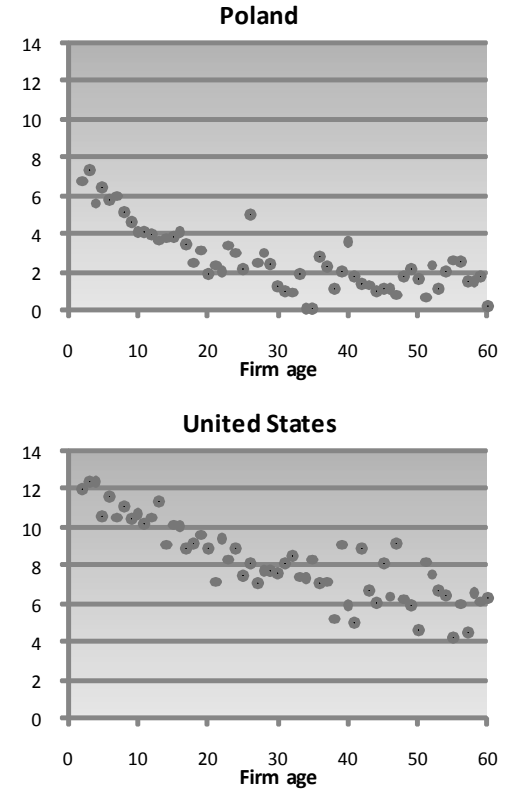

Italy

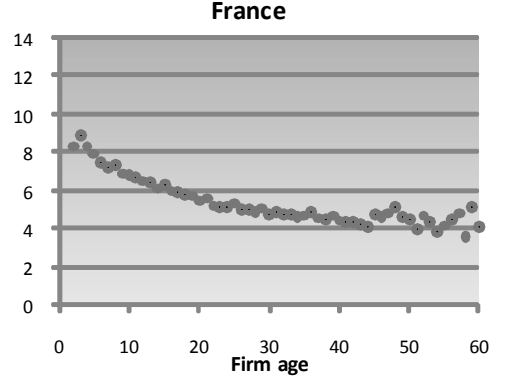

Spain
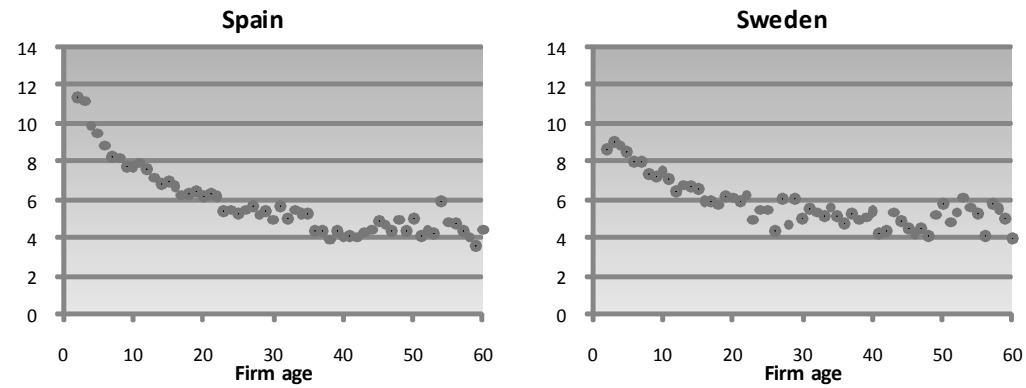
Figure 13. Job creation and destruction as a function of age (cont.)

Average percentage rates adjusted by firm-size, industry, region and year, by country, 2000-2006
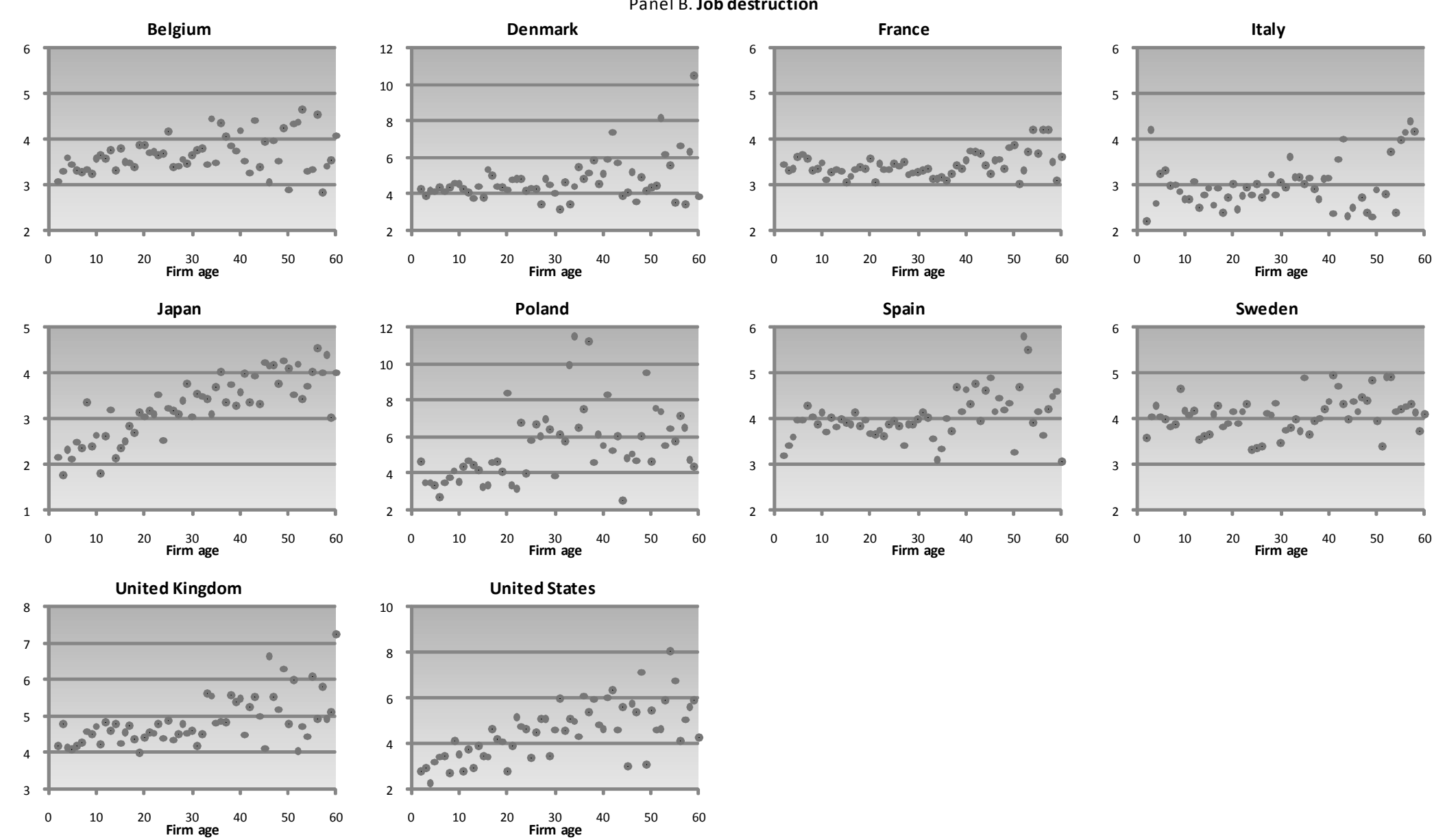

Notes: Firms with less than 20 employees are excluded and aged less than 2 years are excluded. Rates for firms older than 60 years are not shown. Belgium, 2000-04; Denmark, 2001-05; France, 2000-04; Italy, 2002-03; Japan, 2004-06; Poland, 2001-04; Spain, 2001-04; Sweden, 2000-05; the United Kingdom, 2000-04; and the United States, 2005-06. 
63. One can argue, however, that Figure 13 is based on a cross-section of continuing firms, and young firms might disappear well before reaching sixty years. Although this is true, one can expect that the slope of the relationship shown in the figure represents, at worst, an underestimate of the true gradient that would be obtained following the same cohort of firms from the second to the sixtieth year, provided that firms with a greater probability of death do not grow faster (do not contract more slowly) than surviving firms in the years preceding their death.

64. The precision of the estimates presented in Figure 13 declines with age, due to shrinking sample sizes. However, given that the relationship between age and job destruction rates looks approximately linear, it is possible to obtain a clearer image of the cross-country differences observable in Panel B by regressing average estimated job destruction rates on age, using the number of observations at each age as weight, and considering all observations without truncating the sample above the age of sixty years (weights taking care of the lack of precision of estimates at high age). Results suggest that each additional year in the life of a surviving incumbent increases its job destruction rate by at least $0.3 \%$ of its employment, in Poland, Japan and the United States, by about $0.2 \%$ in Denmark, by about $0.1 \%$ in Belgium and the United Kingdom, by about half of that in Italy, Sweden and Spain, and even less in France (Table 14). In the latter country, in particular, job destruction hazards do increase with age, but at a very slow pace. More precisely, estimated coefficients for France are so low that, taking them at face value, 150 years would be necessary to see the average surviving firm increasing its job destruction rate by half of a percentage point.

Table 14. Quantifying the effect of firm age on job destruction for medium and large continuing firms

Regressions of job destruction rates on firm age, by country, 2000-2006

\begin{tabular}{|c|c|c|c|c|c|}
\hline & \\
\hline & Belgium & Denmark & France & Italy & Japan \\
\hline \multirow[t]{2}{*}{ Age } & $0.0118 * * *$ & $0.0242 * * *$ & $0.00298 * *$ & 0.00488 & $0.0319 * * *$ \\
\hline & $(5.489)$ & $(4.759)$ & $(2.513)$ & $(1.621)$ & $(11.80)$ \\
\hline Observations & 112 & 96 & 191 & 116 & 107 \\
\hline R-squared & 0.215 & 0.194 & 0.032 & 0.023 & 0.570 \\
\hline $\mathrm{r} 2$ & 0.215 & 0.194 & 0.032 & 0.023 & 0.570 \\
\hline \multirow[t]{2}{*}{ rmse } & 0.380 & 0.690 & 0.292 & 0.451 & 0.466 \\
\hline & Poland & Spain & Sweden & United Kingdom & United States \\
\hline \multirow[t]{2}{*}{ Age } & $0.0424^{* * *}$ & $0.00600^{* *}$ & $0.00699 * * *$ & $0.0123^{* * *}$ & $0.0392 * * *$ \\
\hline & $(7.804)$ & $(2.235)$ & (3.298) & $(5.145)$ & (8.509) \\
\hline Observations & 149 & 117 & 107 & 134 & 138 \\
\hline R-squared & 0.293 & 0.042 & 0.094 & 0.167 & 0.347 \\
\hline$r 2$ & 0.293 & 0.042 & 0.094 & 0.167 & 0.347 \\
\hline rmse & 1.376 & 0.343 & 0.455 & 0.554 & 1.167 \\
\hline
\end{tabular}

Note: ordinary least square estimation of the percentage point effect of firm age on the job destruction rate. Job destruction rates are adjusted for firm size, geographical area, detailed industry and year. Robust t-statistics in parentheses. ${ }^{* *},{ }^{* * *}$ : statistically significant at the $5 \%$ and $1 \%$ level, respectively. Belgium, 2000-04; Denmark, 2001-05; France, 2000-04; Italy, 2002-03; Japan, 2004-06; Poland, 2001-04; Spain, 2001-04; Sweden, 2000-05; the United Kingdom, 2000-04; and the United States, 2005-06.

65. Cross-country differences in the relationship between age and job destruction are reflected in the cross-age correlation between job creation and job destruction rates. When medium and large continuing firms are grouped by age, on the basis of Figure 13, the correlation between the distributions of job creation and job destruction rates appears always negative, and significant in all except two countries, ranging from -0.07 and -0.13 in France and Italy, respectively, to -0.64 and -0.77 in the United States and Japan, respectively. 
66. Similarly, if we group firms by cells only on the basis of two age categories as well as three size categories, industries and countries as in Table 13 above, we have that in countries such as Denmark, Japan, Poland, the United Kingdom and the United States, those firms that create more jobs tend to destroy fewer of them and vice versa (Table 15). By contrast, in other countries, and particularly in France and Spain, there is no relationship between job creation and job destruction, while Belgium, Finland, Italy and Sweden are characterised by negative but insignificant correlations. Overall these findings suggest that, while industries that create more jobs destroy more jobs, within each industry, the characteristics of firms that create more jobs are different from those that destroy more jobs - at least once entrants, shutdowns and the smallest firms are excluded.

\section{Table 15. Within country/cross - cell correlations of job creation and destruction rates}

Cells defined on the basis of industry, firm-age and firm-size, by country, 2000-06

\begin{tabular}{l|c}
\hline & Correlation \\
\hline France & 0.015 \\
Spain & 0.011 \\
Sweden & -0.062 \\
Belgium & -0.138 \\
Finland & -0.146 \\
Italy & -0.161 \\
Japan & -0.283 \\
Denmark & -0.402 \\
United Kingdom & -0.421 \\
United States & -0.494 \\
Poland & -0.526 \\
\hline
\end{tabular}

Note: Correlation coefficients among job creation and job destruction rates. Firm-level data are grouped into cells according to 21 industry characteristics, three firm-size classes and two firm-age classes. Firms with less than 20 employees are excluded. Belgium, 2000-04; Denmark, 2001-05; Finland, 2002-04; France, 2000-04; Italy, 2002-03; Japan, 2004-06; Poland, 2001-04; Spain, 2001-04; Sweden, 2000-05; the United Kingdom, 2000-04; and the United States, 2005-06.

67. What explains the negative relationship between firm age and job destruction, or more generally between job creation and job destruction across groups of continuers characterised by different age, size and industry? One tentative interpretation of these negative correlations is the following: on the one hand, as noticed above, entry and exit rates are mainly driven by the industry life-cycle and the process of firm learning after birth, as suggested by the high correlation between firm entry and exit rates at the industry (as well as size and age, see literature cited above) level. On the other hand, the dynamics of firm growth conditional on survival appears consistent with predictions of Schumpeterian growth theories (e.g. Aghion and Howitt, 1998). According to the latter, each firm enters the market with a new vintage of up-to-date technology that is, in general, only marginally improved during the firm's life. In this view, older firms are typically characterised by more obsolete technologies and tend to be replaced by younger, more efficient firms. To the extent that product markets are imperfectly competitive, firms with different degrees of efficiency will coexist in the market, but older (less efficient) firms will tend to lose market shares and, consequently, re-adjust the size of their staff.

68. The Schumpeterian interpretation would suggest that countries such as Denmark, Japan, Poland, the United Kingdom and the United States are characterised by a high degree of efficiency-enhancing labour reallocation, insofar as it would reallocate resources from firms with older inefficient technologies to firms with younger more efficient ones. In other countries, in particular France and Spain, this mechanism appears to operate to a lesser extent. We can think of at least three, mutually-exclusive explanations that could account for these pattern differences and would deserve further research: either $i$ ) older firms are not less efficient in these countries, due to their technological specialisation (for instance, they could be specialised in cumulative technologies that favour incumbents and the exploitation of internal labour markets, see e.g. Hall and 
Soskice, 2001, Bassanini and Ernst, 2002, and Wasmer, 2006); or or ii) staffing adjustments are too costly in these countries so that firms tend to minimise them even at the price of efficiency; or iii) product markets are not competitive enough in these countries to force inefficient firms to decline.

69. Is there any evidence that labour resources are reallocated from inefficient to efficient firms? And, do we see this occurring in all market economies? The next subsection look at the link between productivity and firm expansion and contraction.

\subsection{Gross job reallocation and productivity}

70. Most studies have investigated the link between job reallocation and labour productivity using dynamic accounting decompositions, particularly in a single country, including studies for the United States, the United Kingdom, Canada and several developing economies (see e.g. Griliches and Regev, 1995, Haltiwanger, 1997, Foster et al., 2001, Disney et al., 2003, Aw et al., 2001, Baldwin and Gu, 2006). A few studies have investigated these issues using cross-country data (e.g. Brown and Earle, 2008, Bartelsman et al., 2009). These studies typically decompose aggregate labour productivity growth into the contribution of firm entry and exit - which is positive if entrants are more productive than exiting firms and, for continuers, the contribution of within-firm (within-plant) productivity growth at a given employment level and that due to job reallocation among continuing firms. The latter can be further decomposed into a between effect - which is positive if, on average, more productive firms create more jobs and destroy fewer jobs than less productive ones - and a cross effect, which is positive if, at the firm level, net employment growth is positively correlated with productivity growth. ${ }^{19}$ In other words, the between effect captures the gains in aggregate productivity coming from the net employment growth of higher-than-average productivity firms, or from low-productivity firms' shrinking; the cross effect reflects gains in productivity from firms with above-average productivity growth gaining employment shares or from low-productivity-growth firms' shrinking employment shares.

71. The typical finding of these studies is that the contribution from within-firm productivity growth independent of labour reallocation is positive and large. In addition, and more relevant for this paper, they almost always find that job reallocation is also productivity-enhancing. More precisely, they usually find a positive contribution from firm entry and exit - implying that labour tends to be reallocated from less efficient exiting firms to more efficient entrants - and a positive between effect - meaning that labour tends to be reallocated from less to more efficient continuing firms. In some studies the productivity effect of labour reallocation is found to be even larger than the within-firm contribution. Foster et al. (2006), for example, in their study of the US retail industry, find that the contribution of within-firm productivity growth is dominated by the between effect and the contribution of entry and exit. The policy conclusion of this strand of literature is that static allocative efficiency would be maximised if governments removed barriers to labour reallocation. ${ }^{20}$

72. By contrast, the evidence on the cross effect is more mixed. In particular, downsizing firms appear to have above-average labour productivity growth. This pattern can be both explained by different lags in factor adjustments (such as those resulting from quicker adjustment of the mobile factor - labour - with respect to the quasi-fixed factor - physical capital) or by the prevalence of strategically-defensive forms of downsizing: inefficient firms reduce the scale of their operation as they strive to restore their competitiveness. In the few studies that go beyond labour productivity and measure efficiency by multi-factor productivity (MFP), however, this cross effect tends to be less negative (e.g. Brown and Earle, 2008).

19. Some scholars, however, argue that the cross effect should not be included in the contribution of labour reallocation or should be treated as a within-firm effect (see e.g. Brown and Earle, 2008, for a discussion).

20. Conversely, dynamic consequences of the degree of reallocation, for example on investments in matchspecific human capital, are usually not considered in this type of analysis. 
73. Firms are, however, heterogeneous. Dynamic accounting decompositions show that labour tends to be reallocated from less to more efficient firms within a country or an industry. However, it cannot be excluded that this association is simply brought about by the correlation of both employment growth and productivity with other firms' characteristics, rather than a causal effect of greater efficiency on employment growth. For instance, firms in growing metropolitan areas may be more efficient and expand their employment faster than firms in depressed areas. In this case, the dynamism of a few geographical clusters, and the reallocation of labour among clusters with different degrees of dynamism, would be the engine of growth. Therefore, policy efforts to remove possible impediments to labour reallocation that are not targeted at lifting geographical barriers to mobility would not be justified by the evidence. ${ }^{21}$

74. Here, we contribute to shed some light on this issue by exploiting our comparable cross-country micro-data to analyse the covariation of job reallocation and a number of productivity measures, conditional on firm age, detailed firm-size classes, detailed geographical area, detailed industry and common time shocks. Orbis and Amadeus data are available for a sufficiently large and representative number of firms in ten OECD countries (those listed in Table 14 with the exception of the United States). Table 16 shows firm-level correlations between residual employment growth and productivity (that is employment growth and productivity that are not accounted for by the firm's characteristics indicated above) in each of these countries.

75. Firm-level employment changes appear to be correlated with the firm's efficiency level at the beginning of the period with few exceptions, even after controlling for heterogeneity. This holds whether efficiency is proxied by labour productivity - consistent with most of the literature on dynamic accounting decompositions - or is more appropriately measured by MFP. Interestingly, when the MFP measure is used, correlations are stronger. Overall, these results confirm previous findings that the positive "between effect" usually found in decompositions is unlikely to be simply the outcome of firm-level heterogeneity. Job flows among continuers effectively reallocate labour resources from less efficient to more efficient firms.

76. By undertaking a separate analysis for job-creating and job-destroying firms, we can explore further the sources of the productivity-enhancing effect of job reallocation. Efficiency levels turn out to be particularly important for job destruction. Table 16 shows, in fact, that while, among declining firms, less efficient firms tend to experience greater job losses, among expanding firms more efficient firms do not create significantly more jobs, except in Italy and the United Kingdom. On the contrary, in a number of countries, expanding firms with higher labour productivity levels tend to display smaller rates of employment growth.

77. Consistent with the literature on dynamic accounting decompositions, moreover, employment and labour productivity growth appear to be negatively correlated, confirming the evidence on the cross effect discussed above. This correlation is rather widespread: not only does employment decline faster than output in downsizing firms, but also output grows less than employment in expanding firms. However, this occurs, in most cases, without any clear relationship between relative employment and efficiency growth the latter measured by MFP growth.

21. Another caveat to keep in mind is that productivity data typically measure revenue productivity and not technical productivity, that is they are based on both prices and quantities. This implies that a firm sheltered from competition because of some regulatory barrier can set high prices and look very efficient in these data even if it is not, under standard theoretical definitions of efficiency. Like many of the papers discussed above, the analysis presented in this paper does not solve this problem. Foster et al. (2008) is perhaps the only study that distinguishes between revenue and technical productivity. 
DELSA/ELSA/WD/SEM(2009)23

Table 16. Residual correlation coefficients between employment growth and productivity

\begin{tabular}{|c|c|c|c|c|c|c|c|c|c|c|}
\hline \multirow[b]{3}{*}{ Belgium } & \multicolumn{2}{|c|}{$\begin{array}{l}\text { Employment growth } \\
\text { (All) }\end{array}$} & \multicolumn{2}{|c|}{$\begin{array}{l}\text { Employment growth } \\
\text { (growing firms) }\end{array}$} & \multicolumn{2}{|c|}{$\begin{array}{l}\text { Employment growth } \\
\text { (declining firms) }\end{array}$} & $\begin{array}{l}\text { Employment growth } \\
\text { (All) }\end{array}$ & $\begin{array}{l}\text { Employment growth } \\
\text { (growing firms) }\end{array}$ & \multicolumn{2}{|l|}{$\begin{array}{c}\text { Employment growth } \\
\text { (declining firms) }\end{array}$} \\
\hline & \multicolumn{6}{|c|}{$\begin{array}{l}\text { Labour productivity level (lagged) } \\
\end{array}$} & \multicolumn{4}{|c|}{ Multi-factor productivity level (lagged) } \\
\hline & 0.0155 & & -0.1107 & $* * *$ & 0.1252 & *** & $0.1082^{* * *}$ & 0.0242 & $0.1083^{* *}$ & *** \\
\hline Denmark & -0.1039 & *** & -0.1052 & *** & -0.0535 & * & $0.1064^{* * *}$ & 0.003 & $0.1934 * *$ & $* * *$ \\
\hline Finland & 0.0492 & *** & -0.0788 & *** & 0.1711 & $* * *$ & $0.0919^{* * *}$ & -0.0132 & $0.1212 * *$ & *** \\
\hline France & 0.0901 & *** & -0.0086 & & 0.2004 & *** & $0.1063^{* * *}$ & 0.005 & $0.0994 *$ & *** \\
\hline Italy & 0.1244 & *** & 0.0418 & *** & 0.0167 & & $0.1413^{* * *}$ & $0.0657^{* * *}$ & $0.0597 *$ & $* * *$ \\
\hline Japan & 0.068 & *** & 0.0235 & & 0.0977 & $* * *$ & $0.0517^{* * *}$ & 0.0216 & 0.0324 & \\
\hline Poland & 0.115 & *** & 0.1041 & ** & 0.2469 & $* * *$ & 0.034 & 0.0374 & $0.0973 *$ & \\
\hline Spain & 0.0404 & *** & -0.0289 & *** & 0.1098 & *** & $0.0646^{* * *}$ & 0.0066 & 0.011 & \\
\hline Sweden & 0.0978 & *** & -0.0277 & $* * *$ & 0.1167 & $* * *$ & $0.1426^{* * *}$ & 0.0177 & $0.1356 *$ & *** \\
\hline \multirow[t]{2}{*}{ United Kingdom } & 0.0701 & $* * *$ & 0.0581 & $* * *$ & 0.1339 & $* * *$ & $0.1558^{* * *}$ & $0.0273^{* *}$ & $0.1692 * *$ & $* * *$ \\
\hline & \multicolumn{6}{|c|}{ Labour productivity growth } & \multicolumn{4}{|c|}{ Multi-factor productivity growth } \\
\hline Belgium & -0.2052 & $* * *$ & -0.1065 & $* * *$ & -0.146 & $* * *$ & 0.01 & $0.0475^{* * *}$ & 0.0073 & \\
\hline Denmark & -0.0782 & *** & -0.0914 & $* * *$ & -0.1404 & $* * *$ & $-0.0779 * * *$ & 0.0406 & $-0.1933 *$ & *** \\
\hline Finland & -0.1556 & *** & -0.1055 & *** & -0.1629 & $* * *$ & $0.0441 * * *$ & 0.0273 & -0.0272 & \\
\hline France & -0.217 & *** & -0.1684 & $* * *$ & -0.1953 & $* * *$ & -0.001 & $-0.0094 *$ & 0.0045 & \\
\hline Italy & -0.1918 & *** & -0.1389 & *** & -0.2363 & $* * *$ & $0.0188^{* * *}$ & $0.022^{* *}$ & $-0.1265 *$ & $* * *$ \\
\hline Japan & -0.3041 & *** & -0.2706 & *** & -0.2948 & $* * *$ & 0.0163 & -0.0246 & 0.0178 & \\
\hline Poland & -0.1978 & $* * *$ & -0.337 & $* * *$ & -0.1187 & $* *$ & $0.1067^{* * *}$ & $0.1893^{* * *}$ & $-0.1149 *$ & \\
\hline Spain & -0.2614 & *** & -0.2305 & *** & -0.2242 & $* * *$ & $0.0176^{* * *}$ & 0.0075 & -0.0101 & \\
\hline Sweden & -0.1253 & $* * *$ & -0.0988 & $* * *$ & -0.0405 & $* * *$ & $-0.0585 * * *$ & -0.0117 & -0.0155 & \\
\hline United Kingdom & -0.1336 & *** & -0.082 & *** & -0.1449 & $* * *$ & -0.0101 & $0.0455^{* * *}$ & -0.0158 & \\
\hline
\end{tabular}

Notes: size-weighted correlation coefficients among residuals from the employment growth and performance equations of Seemingly Unrelated Regressions (SUR) models including firm age, detailed firm-size classes, detailed geographical areas, detailed industry and common time dummies as co-variates. Growth rates are specified as changes of log variables. Productivity levels are lagged one year. Labour productivity is defined as value added per head. ${ }^{*},{ }^{* *},{ }^{* * *}$ : significant at the $10 \%, 5 \%$ and $1 \%$ level, respectively. Firms with less than 20 employees are excluded. Belgium, 2000-2004, Denmark, 2001-2005, Finland, 2002-2004, France, 2000-2004, Italy, 2002-2003, Japan, 2004-2006, Poland, 2001-2004, Spain, 20012004, Sweden, 2000-2005, and the United Kingdom, 2000-2004. 
DELSA/ELSA/WD/SEM(2009)23

\section{Worker reallocation and demographic characteristics}

78. Firm characteristics are important determinants of job and worker flows. But there are significant cross-worker differences in their exposure to mobility. In this section we exploit the dataset on worker flows presented in Section 2 to explore how a set of workers' characteristics (age, gender and education) shapes the patterns of worker flows across industries and countries. The relevance of these characteristics is underlined by the results of a simple analysis of variance of the type presented in the previous sections. Table 17 shows that gender, age and educational attainment are important determinants of the total variance in workers' flows, even though the analysis is restricted to prime-age workers. ${ }^{22}$ Individual characteristics explain a large share of the total variance $(32.1 \%, 16.3 \%$ and $26 \%$ for hirings, separations and total reallocation, respectively), which is comparable to that accounted for by the country and industry dimensions $(25.7 \%, 20.2 \%$ and $25.7 \%$ for hirings, separations and total reallocation, respectively), even though the number of degrees of freedom is much larger in the case of the latter. Despite the fact that only prime-age workers are considered, individual age appears to be the most important source of variation for hirings. In fact, more than one fourth of their variance appears to be explained by variation across the three retained age categories. By contrast, age shares this role with educational attainment as regards separations (although the linear explanatory power of these variables is smaller, amounting to about $7.5 \%$ for each of them). Gender plays a less prominent role, with less than $2 \%$ of the variation being accounted by this characteristic. However, the F-statistic corresponding to it remains quite large, suggesting that its role should not be neglected. ${ }^{23}$

Table 17. Analysis of variance of prime-age worker flows across countries, industries, gender, age, education

\begin{tabular}{lcc|cc|cc}
\hline & \multicolumn{2}{l|}{ Worker reallocation } & \multicolumn{2}{c|}{ Hiring } & \multicolumn{2}{c}{ Separation } \\
\cline { 2 - 7 } & & & & & & \\
Country & 11.1 & $44.37(16)$ & 9.6 & $44.13(16)$ & 9.8 & $30.03(16)$ \\
Industry & 14.6 & $42.54(22)$ & 16.1 & $53.73(22)$ & 10.3 & $22.87(22)$ \\
Sex & 1.9 & $122.95(1)$ & 1.8 & $130.1(1)$ & 1.3 & $64.9(1)$ \\
Age & 19.1 & $610.91(2)$ & 28.1 & $1033.34(2)$ & 7.4 & $179.94(2)$ \\
Education & 5.0 & $160.5(2)$ & 2.2 & $81(2)$ & 7.6 & $184.15(2)$ \\
& & & & & & \\
Model & 51.6 & $77.02(43)$ & 57.8 & $98.77(43)$ & 36.4 & $41.32(43)$ \\
\hline
\end{tabular}

Notes: Underlying data are aggregated in cells by country, industry, gender, age and educational attainment. The table reports the percentage of the overall variance accounted for by country, industry, gender, age, education. Model refers to the variance explained by the whole regression. F-statistics in italics (with degrees of freedom in parentheses). All components are significant at the $1 \%$ statistical level. As the percentage of the variance explained by each dimension depends on the number of its categories, F-statistics and the ratio of explained variance to the number of degrees of freedom provide information on the relative importance of each dimension. Age refers to adults (25-54 years) separated in three ten-year age bands: 25-34, 35-44, 45-54; Education is is divided in 3 classes: below upper secondary, upper secondary, and tertiary education; industries cover 23 non-farm and non-mining business sectors. There are 17 countries retained in the analysis. Total number of observations is 3145.

22. For the analysis of this section, workers' flows are aggregated into cells by country (17 countries, those in Figure 2 except Poland, Portugal, Slovak Republic, Slovenia and Turkey), industry (23 non-farm and nonmining business sectors, those in Table 1, except the fuel industry), gender (men and women), age (primeage adults aged 25-34, 35-44 and 45-54 years) and educational attainment (less than upper secondary, upper secondary and some post-secondary and tertiary levels). The age coverage is limited to prime-age adults in order to circumvent measurement errors due to small sample sizes for older workers and to avoid capturing the extreme variability in job hiring and separations amongst youths, due to part-time employment while studying.

23. As the percentage of the variance explained by each dimension depends on the number of its categories, F-statistics and the ratio of explained variance to the number of degrees of freedom provide information on the relative importance of each dimension. 
79. Country-specific distributions across cells remain closely correlated. Consistent with the findings of previous sections, if we compare cross-cell distribution of hirings in any particular country with the same distribution within the average country we obtain always a correlation coefficient as high as 0.7 (Figure 14). In the case of separations, the corresponding correlation coefficient is somewhat lower, suggesting a greater heterogeneity across countries, but it is always significant, except for Hungary.

Figure 14. Correlation of country-specific and average hiring and separation rates across industries, gender, age, education

Pairwise correlations between country-specific and an average cross-cell distributions

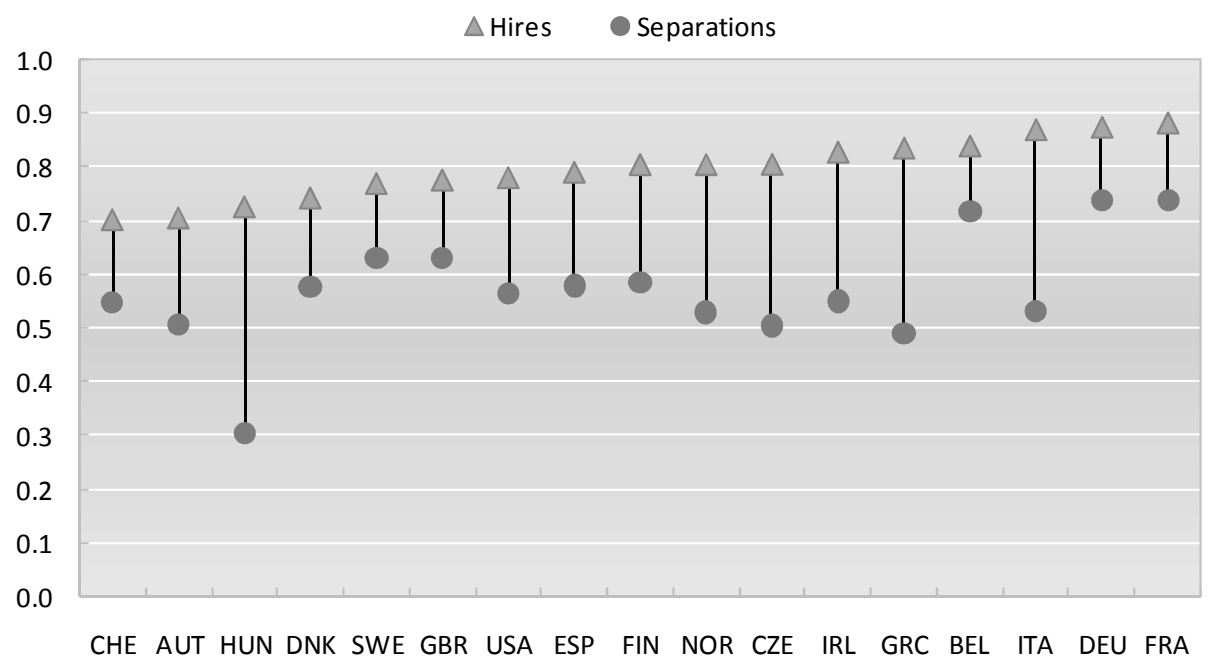

Note: Individual country correlations with an average country across industries and gender, age and educational attainment.

80. In all countries, except Sweden, controlling for differences in the composition of employment by industry, age and educational attainment, hiring rates are higher for women than for men (Table 18). ${ }^{24}$ The same is also true for separations, with the exceptions of Austria, and Hungary. These hiring and separation patterns result in larger reallocation rates for women than for men. On average, almost $19 \%$ of female employees do not remain with the same employer in two consecutive years, against $17 \%$ for their male counterparts. More frequent spells of joblessness are likely to be a key factor in gender differences in reallocation rates. In some countries, these patterns can probably be explained also by the greater share of women having a fixed-term contract. In fact, gender differences in reallocation rates appear particularly large in Spain (more than 10 percentage points), the country with the largest share of temporary workers.

24. Data in Table 18 and Figure 15 are adjusted for composition with respect to other characteristics. For example, Panel A in Table 18 presents estimated patterns by country and gender that would occur in each country if it had the same structure in terms of industry, age and educational attainment as the average country. 
DELSA/ELSA/WD/SEM(2009)23

Table 18. Worker flows by country and individual characteristics

Percentage rates adjusted by industry composition and other individual characteristics, 2000-2005

\begin{tabular}{lc|c|c|c|c|c} 
& \multicolumn{6}{c}{ Panel A. Gender } \\
\cline { 2 - 7 } & \multicolumn{2}{c}{ Hirings } & \multicolumn{2}{c}{ Separations } & \multicolumn{2}{c}{ Worker reallocation } \\
\cline { 2 - 7 } Men & Women & Men & Women & Men & Women \\
\cline { 2 - 7 } BEL & 13.3 & 13.9 & 14.0 & 12.9 & 27.3 & 26.8 \\
CHE & 14.1 & 15.3 & 13.7 & 14.9 & 27.8 & 30.2 \\
CZE & 16.2 & 19.3 & 16.2 & 18.4 & 32.4 & 37.7 \\
DEU & 16.3 & 18.1 & 16.3 & 16.7 & 30.6 & 34.7 \\
DNK & 23.3 & 17.3 & 16.1 & 16.6 & 33.1 & 33.9 \\
ESP & 20.3 & 24.9 & 25.2 & 28.9 & 48.5 & 53.8 \\
FIN & 22.0 & 22.4 & 16.1 & 21.4 & 36.5 & 46.8 \\
FRA & 16.4 & 18.1 & 22.4 & 24.5 & 44.4 & 47.1 \\
GBR & 19.5 & 20.8 & 16.0 & 17.5 & 32.4 & 35.6 \\
GRC & 12.7 & 15.0 & 12.0 & 20.8 & 37.8 & 41.6 \\
HUN & 16.0 & 16.4 & 13.9 & 12.3 & 24.7 & 28.3 \\
IRL & 16.7 & 16.7 & 16.3 & 18.0 & 29.8 & 28.4 \\
ITA & 14.5 & 15.4 & 10.8 & 11.6 & 25.3 & 34.7 \\
NOR & 16.1 & 17.5 & 19.0 & 21.2 & 35.1 & 38.6 \\
SWE & 17.8 & 17.7 & 17.7 & 19.6 & 35.5 & 37.4 \\
USA & 22.6 & 24.1 & 23.6 & 27.4 & 46.2 & 51.5 \\
\hline
\end{tabular}

Panel B. Age

\begin{tabular}{|c|c|c|c|c|c|c|c|c|c|}
\hline & \multicolumn{3}{|c|}{ Hirings } & \multicolumn{3}{|c|}{ Separations } & \multicolumn{3}{|c|}{ Worker reallocation } \\
\hline & $25-34$ & $35-44$ & $45-54$ & $25-34$ & $35-44$ & $45-54$ & $25-34$ & $35-44$ & $45-54$ \\
\hline AUT & 15.1 & 10.9 & 11.5 & 16.2 & 9.8 & 15.3 & 31.3 & 20.7 & 26.8 \\
\hline BEL & 19.7 & 11.9 & 6.8 & 18.3 & 11.4 & 11.4 & 38.0 & 23.3 & 18.2 \\
\hline $\mathrm{CHE}$ & 21.9 & 13.8 & 9.8 & 20.4 & 15.1 & 14.2 & 42.3 & 28.9 & 24.0 \\
\hline CZE & 18.8 & 13.8 & 10.8 & 15.4 & 18.8 & 14.7 & 34.2 & 32.6 & 25.5 \\
\hline DEU & 21.5 & 14.6 & 10.3 & 23.5 & 11.6 & 11.9 & 45.0 & 26.2 & 22.2 \\
\hline DNK & 29.4 & 21.6 & 16.1 & 29.7 & 24.6 & 21.2 & 59.1 & 46.2 & 37.3 \\
\hline ESP & 29.7 & 18.9 & 14.5 & 21.7 & 16.2 & 15.7 & 51.4 & 35.1 & 30.2 \\
\hline FIN & 29.2 & 18.2 & 13.6 & 29.4 & 20.3 & 15.8 & 58.6 & 38.5 & 29.4 \\
\hline FRA & 22.7 & 13.6 & 8.8 & 21.6 & 13.3 & 11.3 & 44.4 & 26.9 & 20.1 \\
\hline GBR & 23.5 & 17.9 & 14.6 & 23.9 & 15.8 & 15.6 & 47.4 & 33.7 & 30.1 \\
\hline GRC & 17.0 & 11.6 & 8.2 & 11.5 & 12.8 & 13.6 & 28.5 & 24.4 & 21.8 \\
\hline HUN & 20.3 & 14.6 & 11.4 & 13.2 & 15.7 & 11.2 & 33.5 & 30.3 & 22.6 \\
\hline IRL & 21.4 & 14.0 & 10.7 & 19.0 & 15.5 & 15.1 & 40.4 & 29.5 & 25.8 \\
\hline ITA & 20.7 & 10.7 & 8.3 & 13.4 & 8.2 & 10.3 & 34.1 & 19.0 & 18.6 \\
\hline NOR & 21.0 & 13.5 & 7.9 & 22.6 & 16.4 & 12.7 & 43.6 & 29.9 & 20.7 \\
\hline SWE & 22.4 & 14.6 & 10.0 & 22.0 & 15.2 & 14.5 & 44.4 & 29.8 & 24.5 \\
\hline USA & 29.6 & 20.5 & 15.4 & 29.8 & 22.4 & 18.6 & 59.4 & 42.8 & 34.0 \\
\hline
\end{tabular}


DELSA/ELSA/WD/SEM(2009)23

Table 18. Worker flows by country and individual characteristics (cont.)

Percentage rates adjusted by industry composition and other individual characteristics, 2000-2005

\begin{tabular}{|c|c|c|c|c|c|c|c|c|c|}
\hline & \multicolumn{3}{|c|}{ Hirings } & \multicolumn{3}{|c|}{ Separations } & \multicolumn{3}{|c|}{ Worker reallocation } \\
\hline & Low & Medium & High & Low & Medium & High & Low & Medium & High \\
\hline AUT & 14.9 & 12.6 & 14.1 & 19.8 & 12.0 & 11.7 & 34.7 & 24.6 & 25.8 \\
\hline BEL & 16.8 & 14.3 & 14.5 & 20.8 & 13.1 & 11.7 & 37.7 & 27.5 & 26.2 \\
\hline $\mathrm{CHE}$ & 16.3 & 16.5 & 20.0 & 23.8 & 15.7 & 16.0 & 40.2 & 32.2 & 36.0 \\
\hline CZE & 19.7 & 14.5 & 17.3 & 29.0 & 13.1 & 15.6 & 48.7 & 27.7 & 32.9 \\
\hline DEU & 20.3 & 16.3 & 18.5 & 26.7 & 13.8 & 14.6 & 46.9 & 30.1 & 33.1 \\
\hline DNK & 29.1 & 23.3 & 23.7 & 34.4 & 26.1 & 18.8 & 63.5 & 49.4 & 42.5 \\
\hline ESP & 24.2 & 23.2 & 22.7 & 22.4 & 18.1 & 16.3 & 46.5 & 41.3 & 39.1 \\
\hline FIN & 23.7 & 23.7 & 20.4 & 32.7 & 23.0 & 19.2 & 56.4 & 46.7 & 39.6 \\
\hline FRA & 20.3 & 16.4 & 17.3 & 21.8 & 15.8 & 14.7 & 42.1 & 32.2 & 32.0 \\
\hline GBR & 21.0 & 20.2 & 20.3 & 23.4 & 18.5 & 17.1 & 44.4 & 38.8 & 37.3 \\
\hline GRC & 16.3 & 11.6 & 14.7 & 18.4 & 9.8 & 11.0 & 34.7 & 21.5 & 25.7 \\
\hline HUN & 21.3 & 14.5 & 16.1 & 17.8 & 11.8 & 16.3 & 39.1 & 26.3 & 32.4 \\
\hline IRL & 19.4 & 15.2 & 20.7 & 21.8 & 16.6 & 13.6 & 41.2 & 31.9 & 34.3 \\
\hline ITA & 15.4 & 12.4 & 25.0 & 13.2 & 8.5 & 21.3 & 28.6 & 20.9 & 46.4 \\
\hline NOR & 16.4 & 14.9 & 20.2 & 24.9 & 16.2 & 21.3 & 41.3 & 31.1 & 41.5 \\
\hline SWE & 17.5 & 16.8 & 22.8 & 24.8 & 15.2 & 19.9 & 42.3 & 32.0 & 42.7 \\
\hline USA & 29.5 & 22.5 & 22.6 & 31.0 & 24.7 & 19.5 & 60.5 & 47.2 & 42.1 \\
\hline
\end{tabular}

Note: Data are ranked in ascending order of worker reallocation rates. Adjusted reallocation rates are estimated average rates that would be observed in each country if it had the same industry composition and individual characteristics as the average country other than the characteristic of interest. Adjusted reallocation, hiring and separation rates are estimated average rates observed across countries. The rates are based on 2002-2005 for the Czech Republic; 2000-2003 for Ireland; 2000-2004 for Norway; $2004-2005$ for Poland; 2003-2005 for the Slovak Republic; 2002-2007 for Switzerland; 2007 for Turkey; and 2000,2002 and 2004 for the United States.

81. In most countries, worker mobility is concentrated among younger prime-age adults (aged from 25 to 34 years). More precisely, there is a strong negative correlation between workers' age and hiring rates in all countries. Hiring rates for people aged between 25 and 34 years are above the country mean by at least 5 percentage points in ten out of 17 countries and particularly higher in Finland, France, Spain and the United States. They then decline with age as workers settle in their jobs and careers and gain experience and seniority. Similarly, separation rates also tend to decline with age, but the age profile is less steep and tends to become flatter above a certain age threshold in many countries. These patterns are not surprising and often observed in the literature (see e.g. Ryan, 2001). They are likely to reflect two intertwined and well-documented phenomena. On the one hand youth engage in "job-shopping" in the early stage of their career in order to find the job that best matches their skills. Better job opportunities in terms of pay and working conditions tend to drive youth job mobility, and job changes in their first years of work experience tend to have a positive impact on the future career paths of youth (Topel and Ward, 1992; Le Minez and Roux, 2002). On the other hand, in many countries, the share of youth labour flows that results from involuntary separations is not negligible: young workers are more often engaged in temporary jobs, as employers use fixed-term contracts to screen new recruits, but also to adjust to changing aggregate demand conditions (see e.g. Barlet et al., 2007).

82. Low-qualified workers - with less than upper secondary education - have consistently greater probability of separation than more qualified workers in all countries, except in Italy - where qualified youth are often older than 25 years at the time of their first entry in the labour market (see OECD, 2008) but there is no systematic relationship between separation hazards and education at higher educational attainment levels. By contrast, hiring varies less by skill levels, except in Denmark, Hungary and in the United States - where hiring rates are substantially higher in the case of low-skilled workers - and Italy, 
Norway and Sweden - where hiring rates are significantly larger for the most educated. These patterns suggest that structural changes in the demand for skills, leading to fewer labour market opportunities for low-educated workers, are reflected in greater separation rates for low-skilled workers than in reductions of hiring. This would suggest that churning rates might also be constant by skill level (see above): firms might accommodate their demand for skills by increasing dismissals of workers with low educational attainment (without reducing hirings from this group) and increasing hirings of more-educated workers (without reducing separations).

83. Structural changes in the demand for skills are also reflected in the relative high mobility of workers with upper secondary education. Overall, labour reallocation appears to be greater at the extremes of the skill distribution (that is, U-shaped), except in countries with the highest overall mobility (such as Finland, United States and Denmark) where it decreases monotonically as the level of educational attainment increases.

84. Looking at the distribution of reallocation rates across industries, it appears that hiring and separation rates of women are about 30\% larger than those of men in manufacturing, where mobility rates are generally low, whereas the gender difference is smaller in services, where mobility rates are generally high (with gender differences often below 10\%, if any, see Figure 15). Hiring rates also decline with age in all industries and so do separation rates but their age profiles tend to become flatter as age increases. More precisely, separation rates vary little with age in low-worker-mobility sectors, particularly in manufacturing, except in declining sectors such as the textiles industries where younger adults separate far more than other adults from their employer. By contrast, in high-mobility sectors mostly in services, separation rates of young adults are higher, possibly as a result of the larger use of fixed-term positions in these industries, typically occupied by young workers. 
DELSA/ELSA/WD/SEM(2009)23

Figure 15. Worker flows by industry and individual characteristics

Hiring, separation and total reallocation percentage rates, 2000-2005

Panel A. Gender

$\Delta$ Men

Women

Hiring

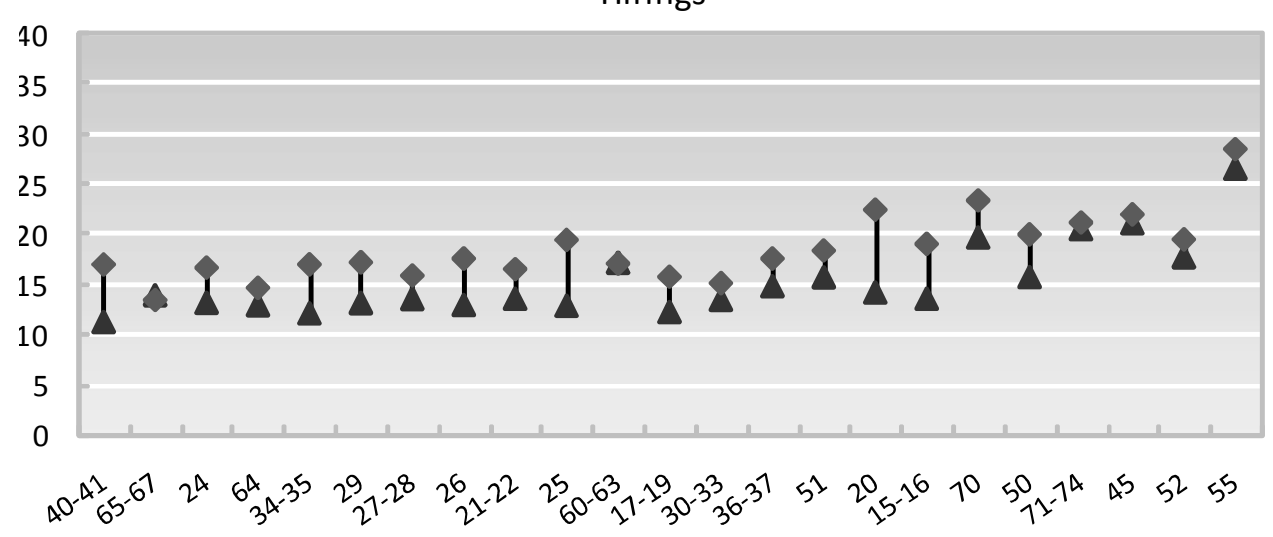

Separations

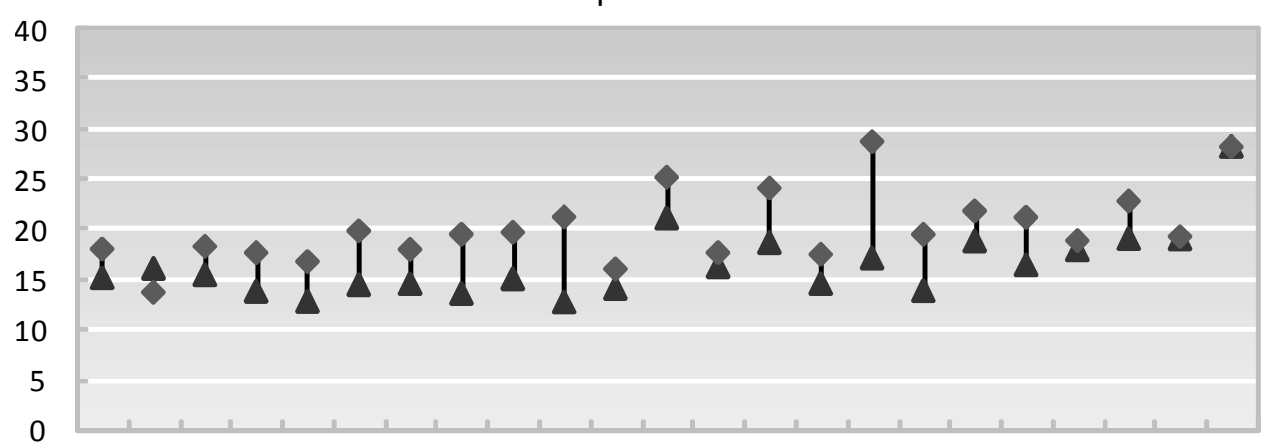

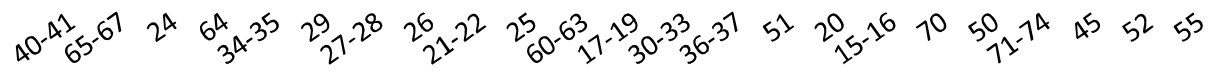

Worker reallocation

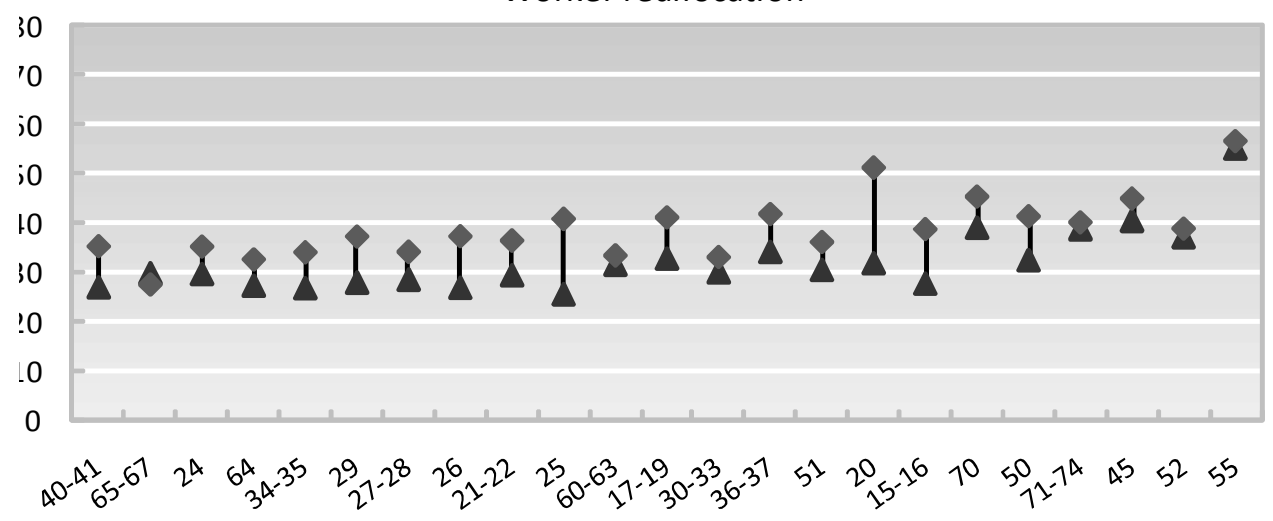

52 
Figure 15. Worker flows by industry and individual characteristics (cont.) Hiring, separation and total reallocation percentage rates, 2000-2005 Panel B. Age

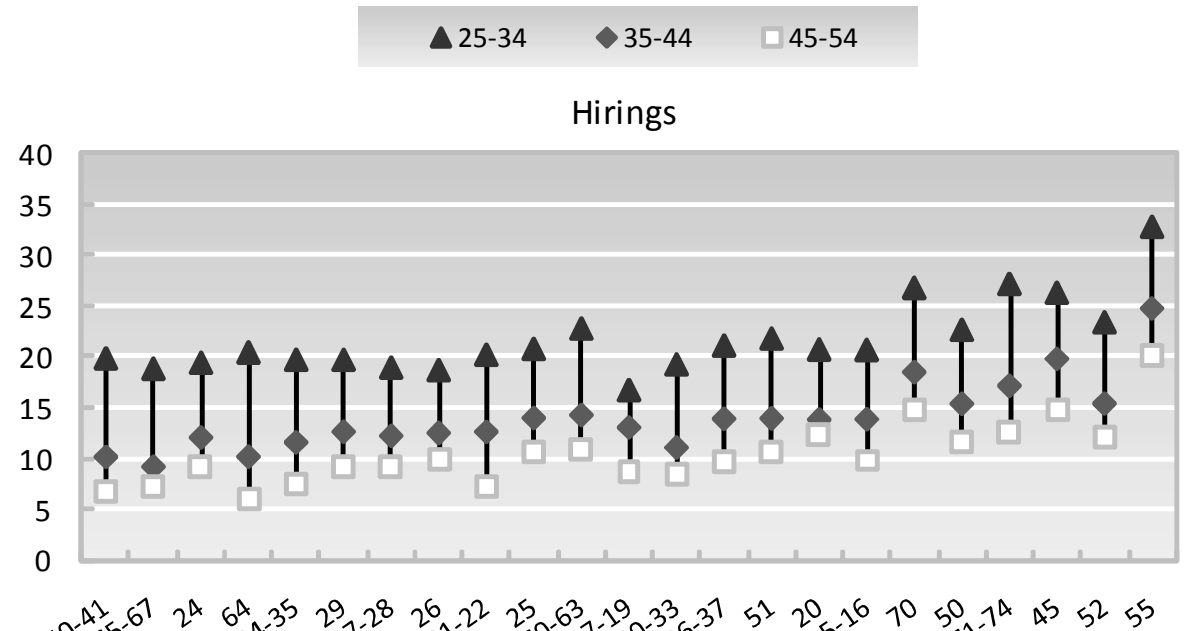

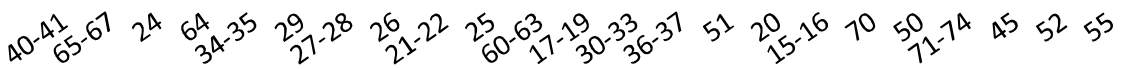

Separations

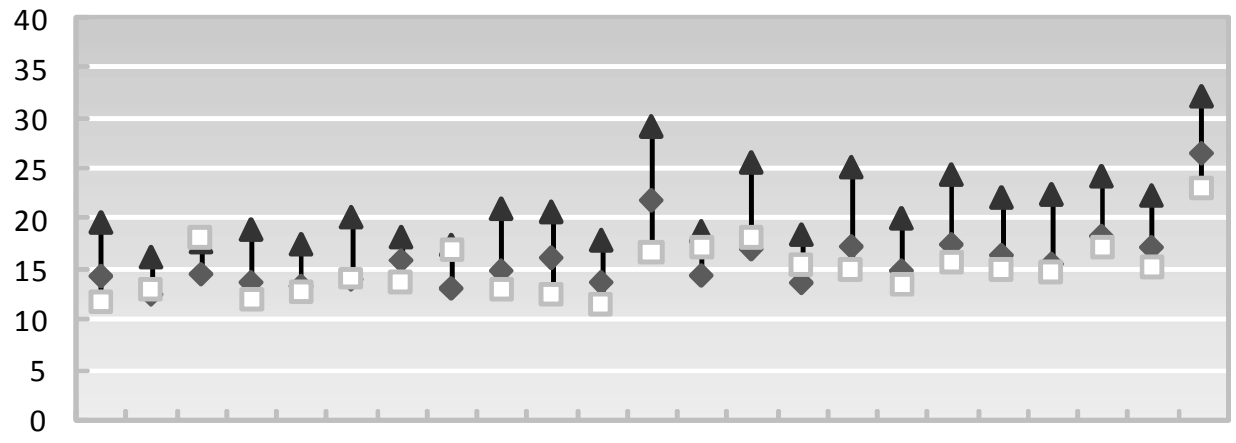

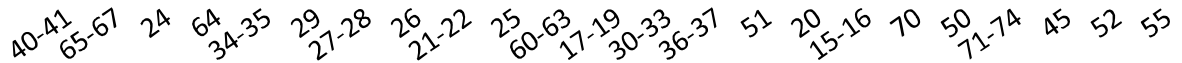

Worker reallocation

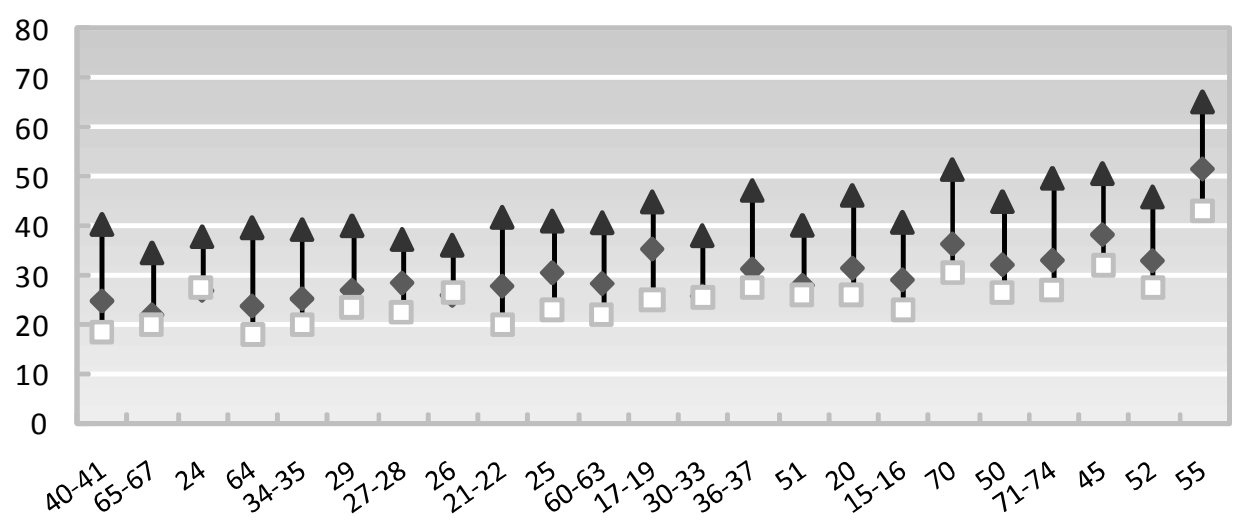


Figure 15. Worker flows by industry and individual characteristics (cont.)

Hiring, separation and total reallocation percentage rates, 2000-2005

Panel C. Educational attainment

$\triangle$ Low $\quad$ Medium $\quad \square$ High

Hirings

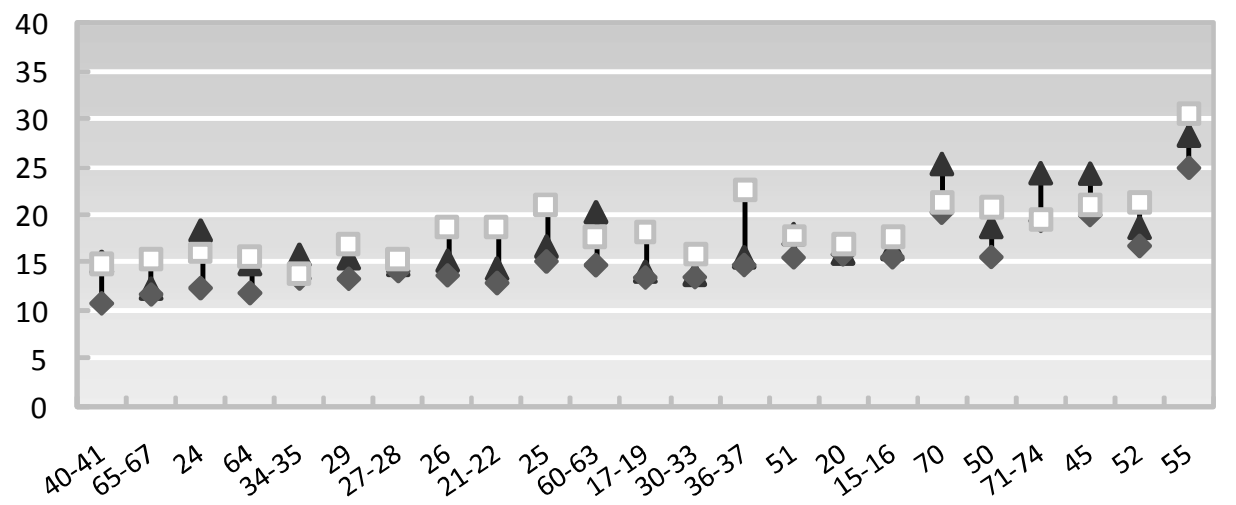

Separations

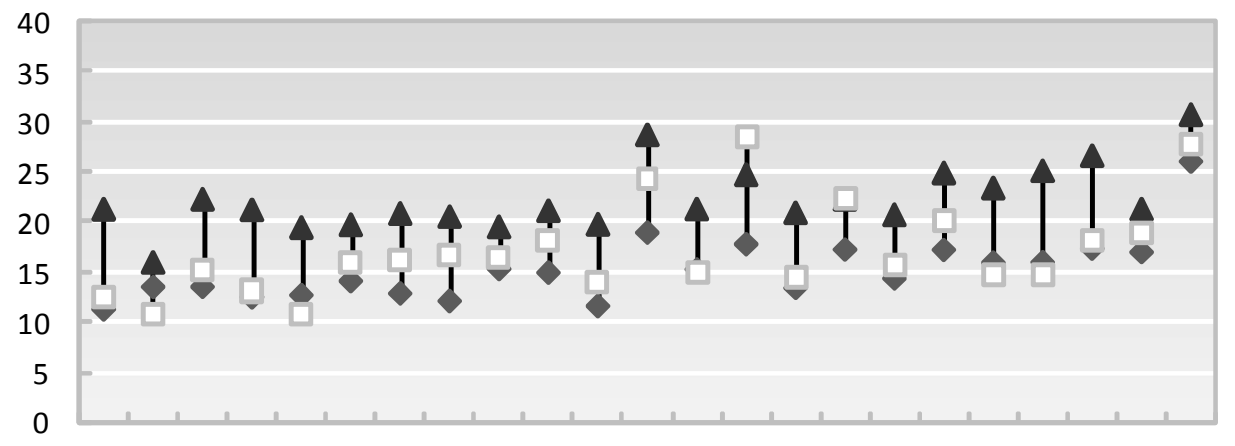

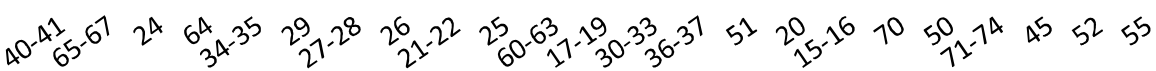

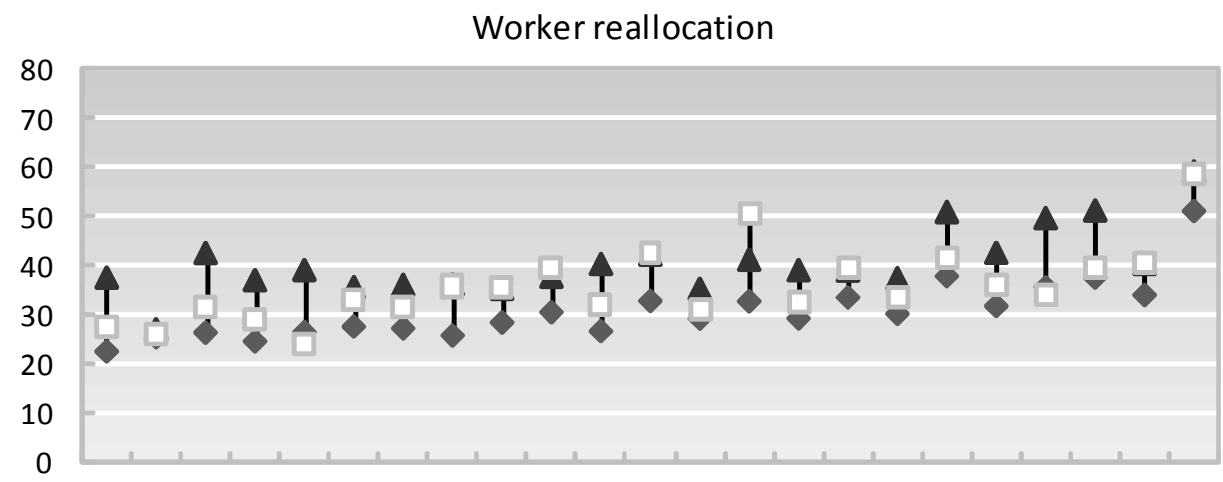

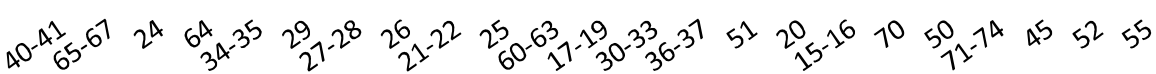

Notes ISIC rev 3. codes for industries (see Table 5 for labels): Data are ranked in ascending order of worker reallocation rates across industries reported in Figure 1. Adjusted reallocation, hiring and separation rates are estimated average rates after controlling for country effects and individual characteristics other than the characteristic of interest. The rates are based on 2002-2005 for the Czech Republic, 2000-2003 for Ireland, 2000-2004, for Norway, 2004-2005, for Poland, 2003-2005 for the Slovak Republic, 2002-2007 for Switzerland, 2007 for Turkey, and 2000, 2002 and 2004 for the United States. 
85. Hiring rates of workers with different qualifications are similar across industries, albeit somewhat higher for high-qualified workers in some industries. In contrast, separation rates follow broadly two patterns depending on the industry. In high-mobility industries, more specifically in non-manufacturing, separation rates within each industry first decline markedly then remain flat as educational attainment increases. In other industries, they are greater at the extremes of the skill distribution.

\section{Concluding remarks}

86. In this paper, we use harmonised data on gross job and worker flows to examine the way these flows vary across OECD countries as well as across industries, firm and individual characteristics. In contrast a common thrust of the literature, we do not find that cross-country differences in gross worker reallocation is greater than differences in job reallocation, at least when they are measured in the same way at annual frequency. Indeed, both job and worker flows appear to vary significantly across countries. Countries where these flows are the largest experience twice as much reallocation as countries where flows are the smallest.

87. Cross-industry differences are equally impressive. Nevertheless, the within-country distributions of gross flows appear quite similar across countries. By contrast, churning flows, that is flows arising from firms churning workers or employees quitting and being replaced, appear to vary very little across countries, although they vary significantly across industries. Moreover, the variation of gross job flows across countries and industries is a good predictor of the corresponding variation of worker flows, suggesting that, to some extent, cross-country/cross-industry comparable data of job and worker flows can be used as mutual substitutes.

88. In all countries, the contribution of both the extensive margin - firm entry and exit - and the intensive margin - growth and contraction of continuers - to job reallocation appear important. Firm age turns out to be a crucial factor, even controlling for other characteristics such as firm size, industry and geographical location, at least for continuers: young firms create more jobs and older firms destroy more jobs, although cross-country differences are large. Finally, in almost all countries for which we have data, inefficient firms destroy more jobs and efficient ones create more jobs. In particular, for downsizing firms the extent of the staff contraction appears to be closely correlated with the firm's pre-contraction efficiency level.

89. Individual characteristics such as age, education and gender are key determinants of worker flows. Hirings decline markedly with age in all countries. In a few countries younger prime-age workers have much larger separation rates than their older counterparts, but this is not the case in others. By contrast, worker reallocation is also more important at the extremes of the skill distribution in most countries. 


\section{REFERENCES}

Abowd, J. and L. Vilhuber (2005), "The Sensitivity of Economic Statistics to Coding Errors in Personal Identifiers", Journal of Business and Economic Statistics, Vol. 23, No. 2, pp. 133-152.

Abowd, J., P. Corbell, and F. Kramarz (1999), "The Entry and Exit of Workers and the Growth of Employment: An Analysis of French Establishments", Review of Economics and Statistics, Vol. 81, No. 2, pp. 170-187.

Acs, Z. J., C. Armington and A. Robb (1999), "Measures of Job Flow Dynamics in the U.S. Economy", CRIEFF Discussion Paper No. 9907.

Aghion, P. and P. Howitt (1998), Endogenous Growth Theory, MIT Press, Cambridge, Mass.

Albæk, K. and B. Sørensen (1998), "Worker flows and job flows in Danish manufacturing, 1980-1991", Economic Journal, Vol. 108, No. 451, pp. 1750-1771.

Arai, M. and F. Heyman (2000), "Permanent and Temporary Labour: Job and Worker Flows in Sweden, 1989-1998", National Institute of Economic Research Working Paper No. 71.

Aw, B. Y., X. Chen and M. J. Roberts (2001), "Firm-Level Evidence on Productivity Differentials and Turnover in Taiwanese Manufacturing", Journal of Development Economics, Vol. 66, No. 1, pp. 51-86.

Baldwin, J. R. and W. Gu (2006), "Plant Turnover and Productivity Growth in Canadian Manufacturing", Industrial and Corporate Change, Vol. 15, No. 3, pp. 417-465.

Bartelsman, E. (2008), "EU KLEMS DMD indicators: Sources and Methods", in M. O'Mahony et al., EUKLEMS - Linked Data: Sources and Methods, mimeo, University of Birmingham, www.euklems.net/data/linked/euklems_linkeddata_sourcesandmethods_220708.pdf

Bartelsman, E., J. Haltiwanger and S. Scarpetta (2009), "Measuring and Analyzing Cross-Country Differences in Firm Dynamics", in T. Dunne, J.B. Jensen and M.J. Roberts (eds.), Producer Dynamics, University of Chicago Press for the NBER, Chicago, Ill.

Bartelsman, E., S. Scarpetta and F. Schivardi (2005), "Comparative Analysis of Firm Demographics and Survival: Evidence from Micro-level Sources in OECD Countries", Industrial and Corporate Change, Vol. 14, No. 3, pp. 365-391.

Bartlet, M., et al. (2007), "Flux de main-d'oeuvre, flux d'emplois et internationalisation, in INSEE", L'économie française, edition 2007, INSEE, Paris.

Bassanini, A., and E. Ernst (2002), "Labour market regulation, industrial relations and technological regimes: a tale of comparative advantage", Industrial and Corporate Change, Vol. 11, No. 3, pp. 391-426. 
Bassanini, A., L. Nunziata and D. Venn (2009), "Job Protection Legislation and Productivity Growth in OECD Countries”, Economic Policy, Vol. 58, pp. 349-402.

Bertola, G., and R. Rogerson (1997), "Institutions and Labor Reallocation”, European Economic Review, vol. 41, pp. 1147-1171.

Benedetto, G., J. Lane, J. Haltiwanger and K. McKinney (2007), "Using Worker Flows to Measure Firm Dynamics", Journal of Business and Economic Statistics, Vol. 25, No. 3, pp. 299-313.

Brandt, N. (2004), “Business Dynamics in Europe”, OECD STI Working Paper No. 2004/1, OECD, Paris.

Brown, J. D. and J. S. Earle (2008), "Understanding the Contributions of Reallocation to Productivity Growth: Lessons from a Comparative Firm-Level Analysis", Upjohn Institute Staff Working Paper No. $08-141$.

Burgess, S., J. Lane and D. Stevens (2000), “Job Flows, Worker Flows and Churning”, Journal of Labor Economics, Vol. 18, No. 3, pp. 473-502.

Burgess, S., J. Lane and D. Stevens (2001), "Churning Dynamics: An Analysis of Hires and Separations at the Employer Level", Labour Economics, Vol. 8, pp. 1-14.

Coen-Pirani, D. and Y. Lee (2007), "Job Flows across U.S. States”, mimeo, Federal Reserve Bank of Cleveland.

Connolly, H. and P. Gottschalk (2004), "Wage Cuts as Investment in Future Wage Growth: Some Evidence", Boston College Working Papers in Economics No. 543.

Conway, P., V. Janod and G. Nicoletti (2005), "Product Market Regulation in OECD Countries: 1998 to 2003", OECD Economics Department Working Papers 419.

Corseuil, C. H. L. (2008), "Testing the Connection between Job Creation and Workers Replacement", paper presented at the EALE Annual Conference, September 2008.

Davis, S. J. and J. Haltiwanger (1992), "Gross Job Creation, Gross Job Destruction and Labor Reallocation", Quarterly Journal of Economics, Vol. 107, No. 3, pp. 819-863.

Davis, S. J. and J. Haltiwanger (1999), “Gross Job Flows”, in O.Ashenfelter and D.Card (eds.), Handbook of Labor Economics, Amsterdam: North-Holland.

Davis, S. J., J. Haltiwanger and S. Schuh (1996), Job Creation and Destruction, MIT Press, Cambridge, Mass.

Davis, S. J., R. J. Faberman and J. Haltiwanger (2006), “The Flow Approach to Labor Markets: New Data Sources and Micro-Macro Links", Journal of Economics Perspectives, Vol. 20, No. 3, pp. 3-26.

Disney, R., J. Haskel, and Y. Heden (2003), "Restructuring and Productivity Growth in UK Manufacturing", Economic Journal, Vol. 113, pp. 666-694.

Faberman, R. J. (2003), "Job Flows and Establishment Characteristics: Variations across U.S. Metropolitan Areas", William Davidson Institute Working Paper No. 609. 
Faberman, R. J. (2007), "The Relationship Between the Establishment Age Distribution and Urban Growth", Federal Reserve Bank of Philadelphia Working Paper No. 07-18.

Foster, L., J. Haltiwanger and C. Syverson (2008), "Reallocation, Firm Turnover, and Efficiency: Selection on Productivity or Profitability?”, American Economic Review, Vol. 98, No. 1, pp. 394-425.

Foster, L., J. Haltiwanger and C. J. Krizan (2001), "Aggregate Productivity Growth: Lessons from Microeconomic Evidence", in E. Dean, M. Harper, and C. Hulten (eds.), New Developments in Productivity Analysis, University of Chicago Press, Chicago.

Foster, L., J. Haltiwanger and C. J. Krizan (2006), "Market Selection, Reallocation, and Restructuring in the U.S. Retail Trade Sector in the 1990s", Review of Economics and Statistics, Vol. 88, No. 4, pp. 748-758.

Golan, A., J. Lane and and E. McEntarfer (2006), "The Dynamics of Worker Reallocation within and across Industries", Economica, Vol. 74, pp. 1-20.

Gomez Salvador, R., J. Messina and G. Vallanti (2004), "Gross job flows and institutions in Europe", Labour Economics, Vol. 11, pp. 469-485.

Griliches, Z. and H. Regev (1995), "Firm Productivity in Israeli Industry: 1979-1988", Journal of Econometrics, Vol. 65, pp. 175-203.

Hall, P. A., and D. Soskice, eds. (2001), Varieties of Capitalism, Oxford: Oxford University Press.

Haltiwanger, J. (1997), "Measuring and Analyzing Aggregate Fluctuations: The Importance of Building from Micro-economic Evidence", Saint Louis Federal Reserve Bank Economic Review, January/February, pp. 35-85.

Haltiwanger, J. and M. Vodopivec (2002), "Gross Worker and Job Flows in a Transition Economy: An Analysis of Estonia”, Labour Economics, Vol. 9, No. 5, pp. 601-630.

Haltiwanger, J. and M. Vodopivec (2003), "Worker Flows, Job Flows and Firm Wage Policies", Economics of Transition, Vol. 11, No. 2, pp. 253-290.

Haltiwanger, J., R. Jarmin and J. Miranda (2008) "Business Formation and Dynamics by Business Age: Results from the New Business Dynamics Statistics", paper presented to the CAED annual conference, Budapest, April 2008.

Haltiwanger, J., S. Scarpetta and H. Schweiger (2006) “Assessing Job Flows across Countries: The Role of Industry, Firm Size and Regulations”, IZA Discussion Paper No. 2450, Bonn.

Hamermesh, D., W. Hassink and J. Van Ours (1996), "New Facts about Factor Demand Dynamics: Employment, Jobs and Workers", Annales d'Economie et Statistique, Vol. 41/42, pp. 21-40.

Hijzen, A., R. Upward and P. Wright (2007), "Job Creation, Job Destruction and the Role of Small Firms: Firm-Level Evidence for the UK”, GEP Discussion Papers No. 07/01, University of Nottingham.

Hohti, S. (2000), "Job Flows and Job Quality by Establishment Size in the Finnish Manufacturing Sector 1980-94”, Small Business Economics, Vol. 15, pp. 265-281. 
Ilmakunnas, P. and M. Maliranta (2003), "The Turnover of Jobs and Workers in a Deep Recession: Evidence from the Finnish Business Sector", International Journal of Manpower, Vol. 24, No. 3, pp. 216-246.

Jovanovic, B. (1982), “Selection and the Evolution of Industry”, Econometrica, Vol. 50, pp. 649-670.

Klepper, S. (1996), "Entry, Exit, Growth, and Innovation over the Product Life Cycle", American Economic Review, Vol. 86, No. 3, pp. 562-583.

Klepper, S. and K. L. Simons (2005), "Industry Shakeouts and Technological Change", International Journal of Industrial Organization, Vol. 23, No. 1, pp. 23-43.

Koeniger, W. and J. Prat (2007), "Employment Protection, Product Market Regulation and Firm Selection”, Economic Journal, Vol. 117, pp. F302-F332.

Le Minez, S. and S. Roux (2002), "Les différences de carrières salariales à partir du premier emploi”, Économie et Statistique, No. 351, pp. 31-64.

Micco, A. and C. Pages (2006), "The Economic Effects of Employment Protection: Evidence from International Industry-Level Data”, IZA Discussion Papers No. 2433, Bonn.

Mortensen, D. T. and C. Pissarides (1994), "Job Creation and Job Destruction in the Theory of Unemployment”, Review of Economic Studies, Vol. 61, No. 3, pp. 397-415.

OECD (1996), Employment Outlook, OECD, Paris.

OECD (2008), Employment Outlook, OECD, Paris.

Postel-Vinay, F. and J. M. Robin (2002), "Equilibrium Wage Dispersion with Worker and Employer Heterogeneity”, Econometrica, Vol. 70, No. 6, pp. 2295-2350.

Pries, M. and R. Rogerson (2005), "Hiring Policies, Labor Market Institutions, and Labor Market Flows", Journal of Political Economy, Vol. 113, No. 4, pp. 811-839.

Ryan, P. (2001), "The School-to-Work Transition: A Cross-National Perspective”, Journal of Economic Literature, Vol. 39, pp. 34-92.

Schivardi F. and R. Torrini (2008), "Identifying the Effects of Firing Restrictions Through Size-Contingent Differences in Regulation", Labour Economics, Vol. 15, No. 2.

Schwellnus, C. and J. Arnold (2008), "Do Corporate Taxes Reduce Productivity and Investment at the Firm Level? Cross-country Evidence from the Amadeus Dataset", OECD Economics Department Working Paper No. 641, OECD, Paris.

Topel, R. H. and M. P. Ward (1992), "Job Mobility and the Careers of Young Men”, Quarterly Journal of Economics, Vol. 107, pp. 439-479.

Wasmer, E. (2006), "General versus Specific Skills in Labor Markets with Search Frictions and Firing Costs”, American Economic Review, Vol. 96, No. 3, pp. 811-831.

Wolfers, J. (2009), Measuring the Effects of Employment Protection on Job Flows: Evidence from Seasonal Cycles, Economic Inquiry, forthcoming. 


\section{OECD SOCIAL, EMPLOYMENT AND MIGRATION WORKING PAPERS}

Most recent releases are:

No. 94 THE LABOUR MARKET INTEGRATION OF IMMIGRANTS AND THEIR CHILDREN IN NORWAY Thomas Liebig (forthcoming)

No. 93 SOCIAL MOBILITY AND SUBJECTIVE WELL-BEING Justina Fischer (forthcoming)

No. 92 HOW EXPENSIVE IS THE WELFARE STATE? GROSS AND NET INDICATORS IN THE OECD SOCIAL EXPENDITURE DATABASE (SOCX)

Willem Adema and Maxime Ladaique (forthcoming)

No. 91 SHOULD PENSION SYSTEMS RECOGNISE “HAZARDOUS AND ARDUOUS WORK”? Asghar Zaidi and Edward Whitehouse (2009)

No. 90 GOING SEPARATE WAYS? SCHOOL-TO-WORK TRANSITIONS IN THE UNITED STATES AND EUROPE Glenda Quintini and Thomas Manfredi (2009)

No. 89 LEGISLATION, COLLECTIVE BARGAINING AND ENFORCEMENT: UPDATING THE OECD EMPLOYMENT PROTECTION INDICATORS Danielle Venn (2009)

No. 88 TOWARDS A FRAMEWORK FOR ASSESSING FAMILY POLICIES IN THE EU Henning Lohmann, Frauke H. Peter, Tine Rostgaard and C. Katharina Spiess (2009)

No. 87 INVESTMENT RISK: IMPACT ON RETIREMENT INCOMES AND GOVERNMENT BUDGETS Edward Whitehouse, Anna Cristina D’Addio and Andrew Reilly (2009)

No. 86 PENSION REFORM IN CHILE REVISITED: WHAT HAS BEEN LEARNED? Augusto Iglesias Palau (2009)

No. 85 INEQUALITY, POVERTY AND SOCIAL POLICY: RECENT TRENDS IN CHILE Osvaldo Larrañaga (2009)

No. 84 PENSION SCHEMES FOR THE SELF-EMPLOYED IN OECD COUNTRIES Jongkyun Choi (2009)

No. 83 WORK, JOBS AND WELL-BEING ACROSS THE MILLENNIUM Andrew Clark (2009)

No. 82 CHILD WELL-BEING AND SOLE PARENT FAMILY STRUCTURE IN THE OECD: AN ANALYSIS Simon Chapple (2009)

No. 81 A GOOD TIME FOR MAKING WORK PAY? TAKING STOCK OF IN-WORK BENEFITS AND RELATED MEASURES ACROSS THE OECD Herwig Immervoll and Mark Pearson (2009)

No. 80 MAIN FEATURES OF THE PUBLIC EMPLOYMENT SERVICE IN POLAND Daniela Kalužná (2009)

No. 79 MANAGING HIGHLY-SKILLED LABOUR MIGRATION: A COMPARATIVE ANALYSIS OF MIGRATION POLICIES AND CHALLENGES IN OECD COUNTRIES Jonathan Chaloff and Georges Lemaitre (2009)

Other series of working papers available from the OECD include: OECD HEALTH WORKING PAPERS 


\section{RECENT RELATED OECD PUBLICATIONS:}

DOING BETTER FOR CHILDREN (2009)

SOCIETY AT A GLANCE - ASIA/PACIFIC EDITION (2009)

OECD REVIEWS OF LABOUR MARKET AND SOCIAL POLICIES: SLOVENIA (2009)

INTERNATIONAL MIGRATION OUTLOOK: SOPEMI (2009)

PENSIONS AT A GLANCE 2009: Retirement-Income Systems in OECD Countries (2009)

JOBS FOR YOUTH: FRANCE (2009)

SOCIETY AT A GLANCE 2009 - OECD Social Indicators (2009)

JOBS FOR YOUTH: AUSTRALIA (2009)

OECD REVIEWS OF LABOUR MARKET AND SOCIAL POLICIES: CHILE (2009)

PENSIONS AT A GLANCE - SPECIAL EDITION: ASIA/PACIFIC (2009)

SICKNESS, DISABILITY AND WORK: BREAKING THE BARRIERS (VOL. 3) - DENMARK, FINLAND, IRELAND AND THE NETHERLANDS (2008)

GROWING UNEQUAL? Income Distribution and Poverty in OECD Countries (2008)

JOBS FOR YOUTH: JAPAN (2008)

JOBS FOR YOUTH: NORWAY (2008)

JOBS FOR YOUTH: UNITED KINGDOM (2008)

JOBS FOR YOUTH: CANADA (2008)

JOBS FOR YOUTH: NEW ZEALAND (2008)

JOBS FOR YOUTH: NETHERLANDS (2008)

OECD LABOUR FORCE STATISTICS: 1987-2007 (2008)

JOBS FOR IMMIGRANTS (Vol.2): Labour Market Integration in Belgium, France, the Netherlands and Portugal (2008)

IMMIGRANT HEALTH WORKERS IN OECD COUNTRIES IN THE BROADER CONTEXT OF HIGHLY SKILLED MIGRATION (2008)

INTERNATIONAL MIGRATION OUTLOOK (2008)

OECD EMPLOYMENT OUTLOOK (2008)

OECD REVIEWS OF LABOUR MARKET AND SOCIAL POLICIES IN SERBIA (2008)

A PROFILE OF IMMIGRANT POPULATIONS IN THE $21^{\text {ST }}$ CENTURY (2008)

MODERNISING SOCIAL POLICY FOR THE NEW LIFE COURSE (2007)

BABIES AND BOSSES - Reconciling Work and Family Life: A Synthesis of Findings for OECD Countries (2007)

BENEFITS AND WAGES - OECD Indicators (2007)

For a full list, consult the OECD On-Line Bookstore at www.oecd.org 